ANL-8015

Yo- $79 a$

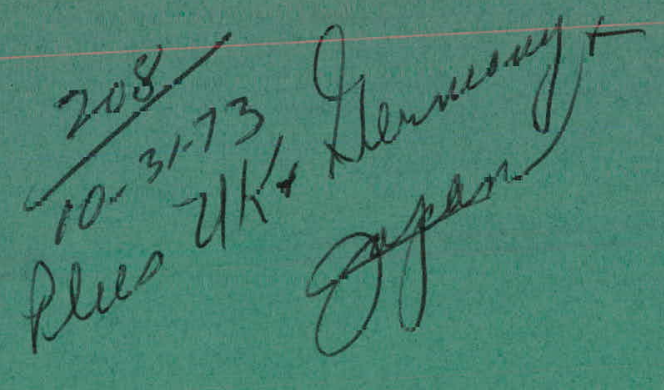

ANL-8015

\title{
A GENERALIZED METHOD OF COMPUTING CARBON-DIFFUSION PROFILES \\ IN AUSTENITIC STAINLESS STEELS \\ EXPOSED TO A SODIUM ENVIRONMENT
}

R. B. Snyder, K. Natesan,

and T. F. Kassner

BASE TECHNOLOGY

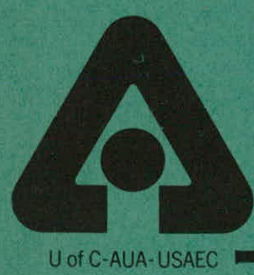

ARGONNE NATIONAL LABORATORY, ARGONNE, ILLINOIS

Prepared for the U.S. ATOMIC ENERGY COMMISSION

Division of Reactor Research and Development

under Contract W-31-109-Eng-38 


\section{DISCLAIMER}

This report was prepared as an account of work sponsored by an agency of the United States Government. Neither the United States Government nor any agency Thereof, nor any of their employees, makes any warranty, express or implied, or assumes any legal liability or responsibility for the accuracy, completeness, or usefulness of any information, apparatus, product, or process disclosed, or represents that its use would not infringe privately owned rights. Reference herein to any specific commercial product, process, or service by trade name, trademark, manufacturer, or otherwise does not necessarily constitute or imply its endorsement, recommendation, or favoring by the United States Government or any agency thereof. The views and opinions of authors expressed herein do not necessarily state or reflect those of the United States Government or any agency thereof. 


\section{DISCLAIMER}

Portions of this document may be illegible in electronic image products. Images are produced from the best available original document. 
The facilities of Argonne National Laboratory are owned by the United States Government. Under the terms of a contract (W-31-109-Eng-38) between the U. S. Atomic Energy Commission, Argonne Universities Association and The University of Chicago, the University employs the staff and operates the Laboratory in accordance with policies and programs formulated, approved and reviewed by the Association.

\section{MEMBERS OF ARGONNE UNIVERSITIES ASSOCIATION}

The University of Arizona Carnegie-Mellon University Case Western Reserve University The University of Chicago University of Cincinnati Iilinuis Institute of Technology University of Illinois Indiana Unlvel sity Iowa State University The University of Iowa
Kansas State University The University of Kansas Loyola University Marquette University Michigan State University The University of Michigan University uf Minnosota. University of Missuur i Northwestern Unlveisity University of Notre Dame
The Ohio State University

Ohio University

The Pennsylvania State University Purdue University

Saint Louis University

Southern Illinois University The University of Texas at Austin Washington Universily Wayne State University The University of Wisconsin

\section{NOTICE}

This report was prepared as an account of work sponsored by the United States Government. Neither the United States nnr the United States Atomic Energy Commission, nor any of their employees, nor any of their contrastnrs, subcontractors, or their employees, makes any warranty, express or implied, or assumes any legal liability or responsibility for the accuracy, complotenessnr usefulness of any information, apparatus, product or process disclosed, or represents lliat its use would not infringe privately-owned rights.

Printed in the United States of America Available from

National Technical Information Service

U.S. Department of Commerce

5285 Port Royal Road

Springfield, Virginia 22151

Price: Printed Copy \$5.45; Microfiche $\$ 0.95$ 
ANL-8015

LMFBR Sodium Technology (UC-79a)

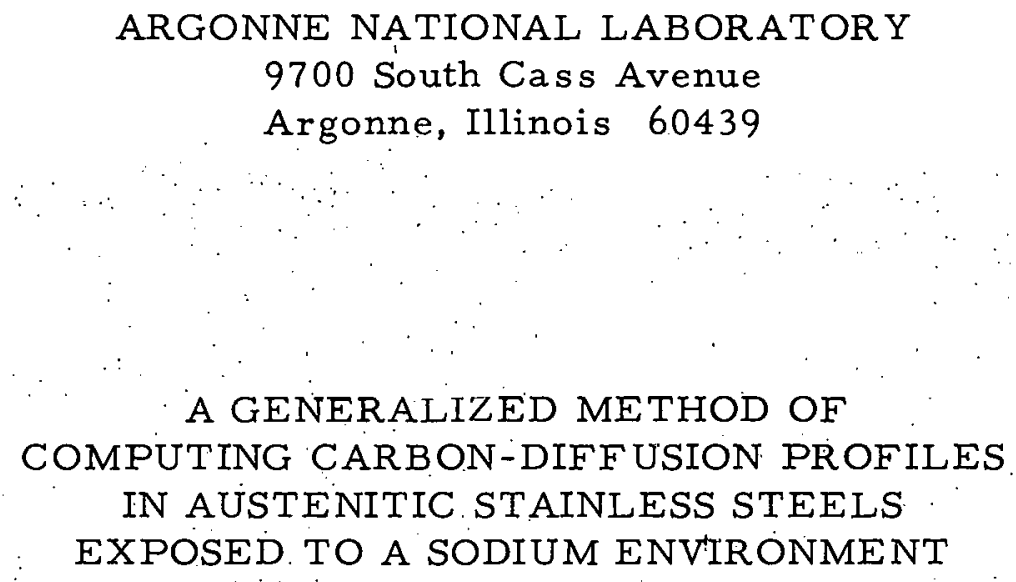

by

R. B. Snyder, K. Natesan, and T. F. Kassner

Materials Science Division

June 197.3

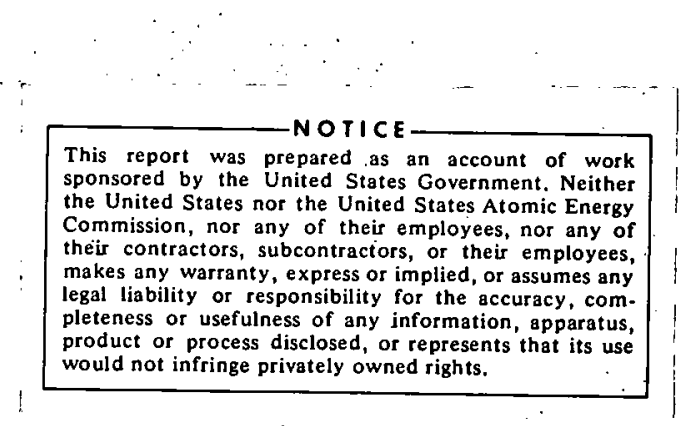




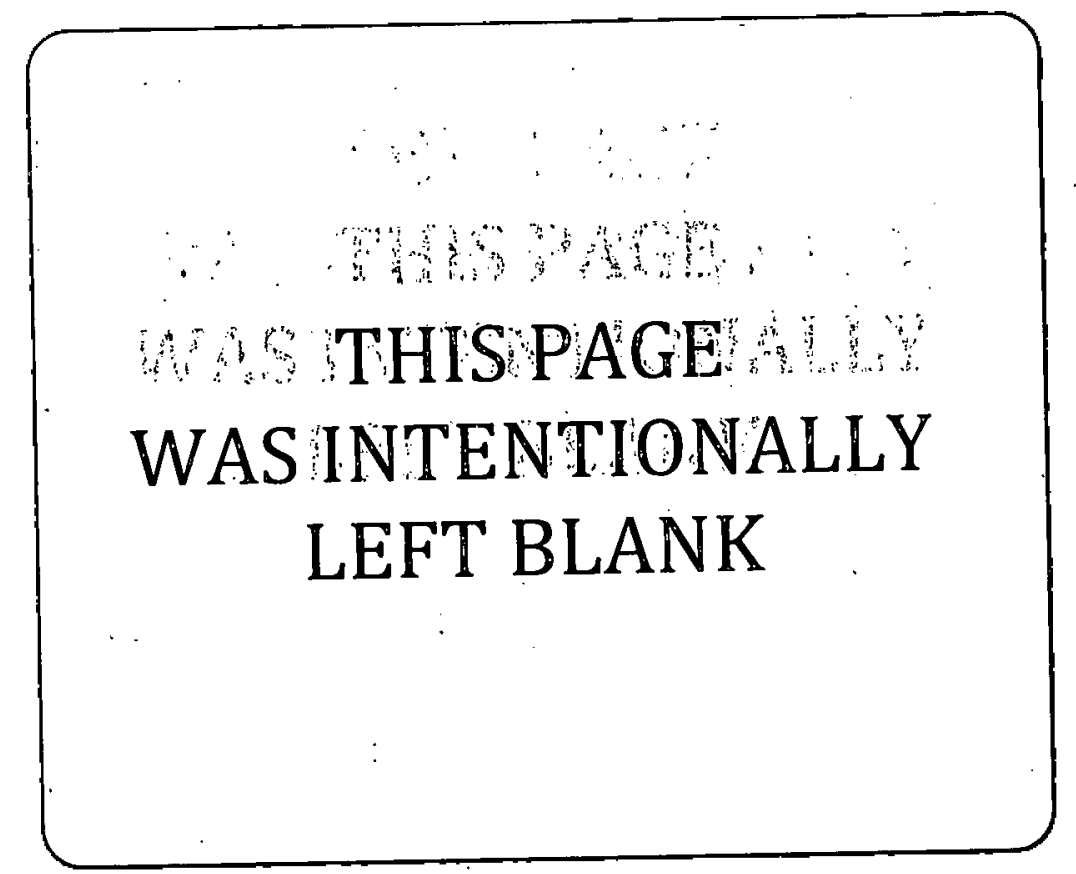

(j)

ลิ. 
TABLE: OF CONTENTS

Page

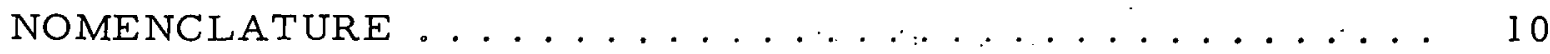

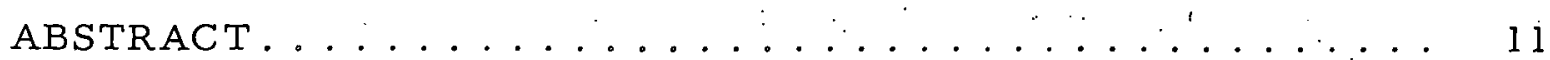

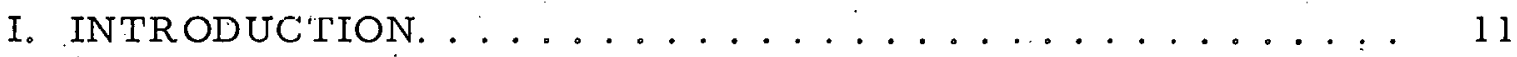

II. CARBON-DIFFUSION ANALYSIS. . . . . . . . . . . 12

A. Development of Diffusion Relations.............. 12

B. Thermodynamic and Kinetic Input Parameters . ....... 15

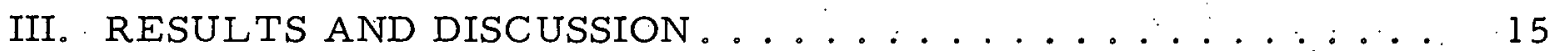

A. Comparison of Calculated and Experimental Carbondiffusion Profiles in Austenitic Stainless Steels ....... 15

B. Influence of Time, Temperature, and Carbon Concentra tion in Sodium on Calculated Carbon-diffusion Profiles in Austenitic Stainless Steels.................. 17

IV. APPLICATIONS OF THE ANALYSIS TO REACTOR

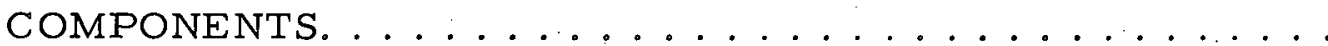

A. Carburization-Decarburization Behavior of Type 316 Stainless Steel Fuel Cladding. ............. 22

B. Carburization of Type 304 Stainless Steel Intermediate Heat-exchanger Piping by Primary- and Secondary-

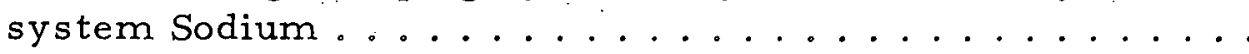

V. CONCLUSIONS AND FUTURE WORK. . . . . . . . . . . 28

\section{APPENDIXES}

A. Thermodynamic, Kinetic, and Microstructural Information for Austenitic Stainless Steels.............. 30

1. Carbon-diffusion Data ................. 30

2. Carbon Activity, Solubility, and Phase-equilibria Data for Temperatures between 600 and $800^{\circ} \mathrm{C} \ldots \ldots$

3. Data for the Metastable Equilibrium between the Austenite and Carbide Phases at Temperatures between 400 and $600^{\circ} \mathrm{C} \ldots \ldots \ldots$ 


\section{TABLE OF CONTENTS}

$\underline{\text { Page }}$

B. Solubility of Carbon in Sodium . . . . . . . . . 40

C. Computer Program for Generating Solutions to the Diffusion Equations . . . . . . . . . . . . 42

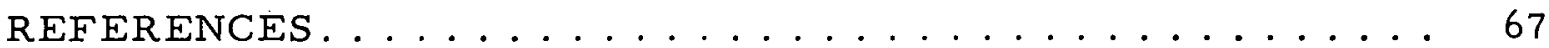




\section{LIST OF FIGURES}

No.

Title

Page

1. Comparison of Experimental and Calculated Carbon-diffusion Profiles for Type 316 Stainless Steel after Exposure to Flowing Sodium for $3864 \mathrm{hr}$ at $650^{\circ} \mathrm{C} \ldots \ldots \ldots$

2. Comparison of Experimental and Calculated Carbon-diffusion Profiles for Type 316 Stainless Steel after Exposure to Flowing Sodium for $4368 \mathrm{hr}$ at $650^{\circ} \mathrm{C} \ldots \ldots \ldots$

3. Comparison of Experimental and Calculated Carbnn-diffusion Profiles fnr Typc 316 Stainless Steel after Exposure to Flowing Sodium for $8760 \mathrm{hr}$ at $650^{\circ} \mathrm{C} \ldots \ldots \ldots$

4. Effect of Temperature on Carbon Concentration-Distance Profiles in 20\% Cold-worked Type 316 Stainless Steel after 1000 -hr Exposure to Sodium Containing 0.017 ppm Carbon...

5. Effect of Temperature on Carbon Concentration-Distance Profiles in 20\% Cold-worked Type 316 Stainless Steel after 4000-hr Exposure to Sodium Containing 0.017 ppm Carbon...

6. Carburization and Decarburization Profiles in Solutionannealed Type 304 Stainless Steel after $10,000 \mathrm{hr}$ at $650^{\circ} \mathrm{C}$ for Various Carbon Levels in Sodium ..............

7. Effect of Initial Carbon Content of Solution-annealed Type 304 Stainless Steel on the Carbon-diffusion Profiles after 10,000-hr Exposure to Sodium Containing $0.13 \mathrm{ppm}$ Carbon

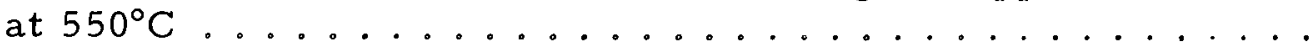

8. Effect of Initial Carbon Content of Solution-annealed Type 304 Stainless Steel on the Carbon-diffusion Profiles after 10,000-hr Exposure to Sodium Containing 0.13 ppm Carbon at $700^{\circ} \mathrm{C} \ldots \ldots \ldots \ldots \ldots$

9. Effect of Temperature between 400 and $800^{\circ} \mathrm{C}$ on the Carburization-Decarburization Behavior of Solution-annealed Type 304 Stainless Steel after 4000-hr Exposure to Sodium

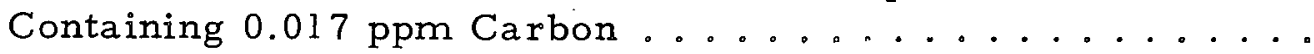

10. Effect of Tcmperature between 400 and $800^{\circ} \mathrm{C}$. on the Carburization-Decarburization Behavior of Solution-annealed Type 304 Stainless Steel after 10,000-hr Exposure to Sodium

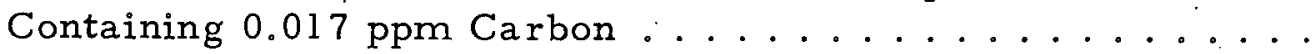

11. Effect of Temperature between 400 and $800^{\circ} \mathrm{C}$ on the Carburization-Decarburization Behavior of Solution-annealed Type 304 Stainless Steel after 1000-hr Exposure to Sodium

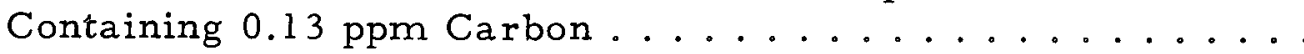




\section{LIST OF FIGURES}

No.

Title

$\underline{\text { Page }}$

12. Effect of Temperature between 400 and $800^{\circ} \mathrm{C}$ on the

Carburization-Decarburization Behavior of Solution-annealed

Type 304 Stainless Steel after 10,000-hr. Exposure to Sodium

Containing $0.13 \mathrm{ppm}$ Carbon . . . . . . . . . . . .

13. Effect of Temperature between 400 and $800^{\circ} \mathrm{C}$ on the

Carburization-Decarburization Behavior of Solution-annealed

Type 316 Stainless Steel after 10,000-hr Exposure to Sodium

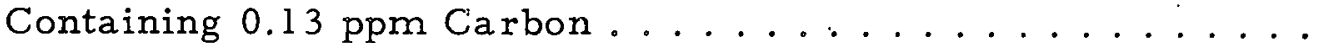

14. Effect of Temperature between 400 and $800^{\circ} \mathrm{C}$ on the

Carburization-Decarburization Behavior of $20 \%$ Cold-worked

Type 316 Stainless Steel after 10,000-hr Exposure to Sodium

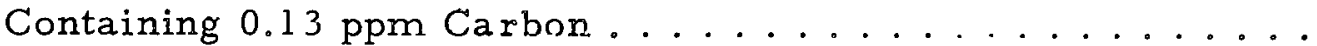

15. Relationship between the Axial Temperature Profile for a

Fuel Pin and the Average Carbon Content of the 15-mil-wall $20 \%$ Cold-worked Type 316 Stainless Steel Cladding after $1000-$ and 5000-hr Exposure to Sodium Containing 0.017 and

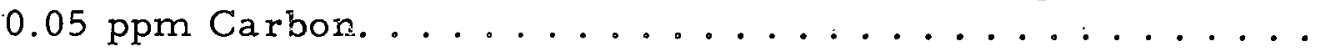

16. Carbon Concentration-Distance Profiles across the $20 \%$ Cold-worked Type 316 Stainless Steel Cladding Wall at 500, 600 , and $700^{\circ} \mathrm{C}$ after $5000-\mathrm{hr}$ Exposure to Sodium Containing

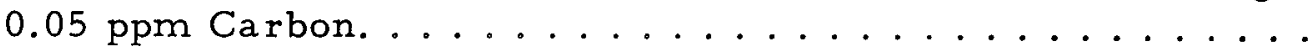

17. Carbon Concentraliun-Distance Profiles across Type 304 Stainless Steel IHX Piping after Exposure to Primary- and Secondary-system Sodium Containing 0.05 and $0.13 \mathrm{ppm}$ Carbon, Respectively, for up to $30 \mathrm{yr}$ at $600^{\circ} \mathrm{C} \ldots \ldots$......

18. Carbon Concentration-Distance Profiles across Type 304 Stainless Steel IHX Piping àfter Exposure to Primary- and Secondary-system Sodium Containing 0.05 and $0.13 \mathrm{ppm}$ Carbon, Respectively, for up to $30 \mathrm{yr}$ at $550^{\circ} \mathrm{C} \ldots \ldots$

19. Carbon Concentration-Distance Profiles across Type 304 Stainless Steel IHX Piping after Exposure to Primary- and Secondary-system Sodium Containing 0.05 and $0.13 \mathrm{ppm}$ Carbon, Respectively, for up to $30 \mathrm{yr}$ at $500^{\circ} \mathrm{C} \ldots \ldots$

20. Carbon Concentration-Distance Profiles across Type 304 Stainless Steel IHX Piping after Exposure to Primary- and Secondary-system Sodium Containing 0.05 and $0.13 \mathrm{ppm}$ Carbon, Respectively, for up to $30 \mathrm{yr}$ at $467^{\circ} \mathrm{C} \ldots \ldots \ldots$ 


\section{LIST OF FIGURES}

No.

Title

Page

21. Carbon Concentration-Distance Profiles across Type 304

Stainless Steel IHX Piping after Exposure to Primary-and Secondary-system Sodium Containing 0.05 and $0.13 \mathrm{ppm}$

Carbon, Respectively, for up to $30 \mathrm{yr}$ at $443^{\circ} \mathrm{C} \ldots \ldots \ldots$

A.1. Temperature Dependence of Diffusion Coefficient for Carbon

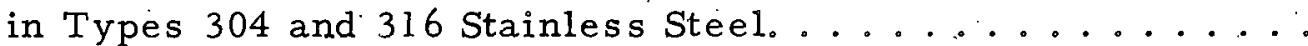

A.2. Carbon Isoactivity Lines and Snlubility of Carbon in $\mathrm{Fe}-\mathrm{Cr}-8$ wt $\% \mathrm{Ni}$ Alloys at $700^{\circ} \mathrm{C} \ldots \ldots \ldots$

A.3. Relationship between Carbon Concentration in the Austenite Phase and Total Carbon Content of an $\mathrm{Fe}-18$ wt \% $\mathrm{Cr}$ 8 wt $\% \mathrm{Ni}$ Alloy at Temperatures between 600 and $1.000^{\circ} \mathrm{C}$...

A.4. Effect of Temperature on Concentration of Carbon in the Austenite Phase at the Sodium-Steel Interface $C_{S}$ and That within the Material $\bar{C}$ for Annealing Times of 1000,4000 , and 10,000 hr for Solution-annealed Type 316 Stainless Steel with an Initial Carbon Concentration of 0.05 wt $\% \ldots . . .$.

A.5. Effect of Temperature on Concentration of Carbon in the Austenite Phase at the Sodium-Steel Interface $\mathrm{C}_{S}$ and That within the Material $\bar{C}$ for Annealing Times of 1000,4000 , and $10,000 \mathrm{hr}$ for $20 \%$ Cold-worked Type 316:Stainless Steel with an Initial Carbon Concentration of 0.05 wt $\%$......

A.6. Effect of Temperature on Concentration of Carbon in the Austenite Phase at the Sodium-Steel Interface $\mathrm{C}_{\mathbf{S}}$ and That within the Material $\overline{\mathrm{C}}$ for Annealing Times of 1000,4000, and 10,000 hr for Solution-annealed Type 304 Stainless Steel with an Initial Carbon Concentration of 0.02 wt $\%$. . . . .

A.7. Effect of Temperature on Concentration of:Carbon in the Austenite Phase at the Sodium-Steel Interface $\mathrm{C}_{\mathrm{s}}$ and That within the Material $\bar{C}$ for Annealing Times of 1000, 4000, and $10,000 \mathrm{hr}$ for Solution-annealed Type 304 Stainless Steel with an Initial Carbon Concentration of 0.05 wt $\% \ldots . . .3$

A.8. Effect of Temperature on Concentration of Carbon in the Austenite Phase at the Sudium-Steel Interface $C_{S}$ and That within the Material $\bar{C}$ for Annealing Times of 1000,4000, and 10,000 hr for Solution-annealed Type 304 Stainless Steel with an Initial Carbon Concentration of 0.08 wt $\% \ldots \ldots$ 


\section{LIST OF FIGURES}

No.

Title

Page

A.9. Relationship between Carbon Concentration in the Austenite Phase and Total Carbon Content of Solution-annealed

Type 304 Stainless Steel after $4000 \mathrm{hr}$ at Temperatures between 400 and $550^{\circ} \mathrm{C}$ under Metastable Austenite-Carbide

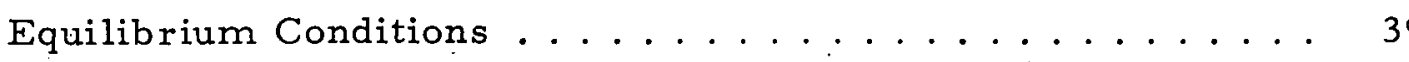

B.1. Temperature Dependence of Carbon Solubility in Sodium . . . 40

C.1. Simplified Flow Diagram for Generating Carbon-diffusion.

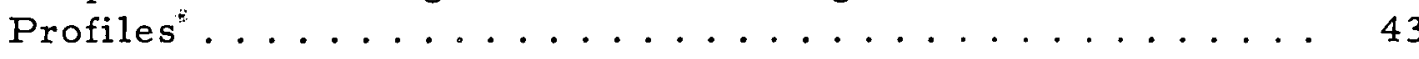


LIST OF TABLES

I. Mass of Carbon Gained or Lost from a 1-cm Length of $20 \%$ Cold-worked Type 316 Stainless Steel Fuel Cladding as a Cold-worked Type 316 Stainless Steel Fuel Cladding as Function of Temperature and Carbon Concentration in Sodium after an Exposure of 1000 and $5000 \mathrm{~h}$

II. Calculated Average Carbon Concentrations for Sections of Type 304 Stainles Stccl Piping after Exposiare to Budiun Containing 0.05 and 0.13 ppn Carbon at Temperatures between 443 and $600^{\circ} \mathrm{C}$ for up to $30 \mathrm{yr} \ldots \ldots \ldots \ldots$

C.1. Program Listing and an Example of Computer Output...... 
NOMENCLATURE

\begin{tabular}{|c|c|c|c|}
\hline $\begin{array}{l}\text { English } \\
\text { Letters }\end{array}$ & & $\mathrm{N}_{\mathrm{C}}$ & $\begin{array}{l}\text { Mole fraction of carbon in the austenite } \\
\text { phase }\end{array}$ \\
\hline${ }_{\mathrm{C}}^{\mathrm{Fe}}-\mathrm{Cr}-\mathrm{Ni}-\mathrm{C}$ & $\begin{array}{l}\text { Carbon activity in } \mathrm{Fe}-\mathrm{Cr}-\mathrm{Ni}-\mathrm{C} \\
\text { alloys }\end{array}$ & $\mathrm{N}_{\mathrm{C}}^{i}$ & $\begin{array}{l}\text { Initial mole fraction of carbon in the } \\
\text { austenite phase }\end{array}$ \\
\hline$a_{C}^{\mathrm{Na}}$ & Carbon activity in sodium & $\mathrm{N}_{\mathrm{C}}^{\circ}$ & Iterative constant in Eq. 8 \\
\hline$a_{C}^{\text {sat }}$ & $\begin{array}{l}\text { Carbon activity at } \gamma / \gamma \text { plus carbide- } \\
\text { phase boundary }\end{array}$ & $\mathrm{N}_{\mathrm{C}}^{\mathrm{s}}$ & $\begin{array}{l}\text { Mole fraction of carbon in the austenite } \\
\text { phase at the sodium-steel interface }\end{array}$ \\
\hline$B_{n}$ & $\begin{array}{l}\text { Constants that are a function of the } \\
\text { eigenvalues }\left(\lambda_{n} \text { and } \delta_{n}\right) \text { obtained } \\
\text { from a comriputer solution to the }\end{array}$ & $\mathrm{N}_{C_{r}}$ & $\begin{array}{l}\text { Mole fraction of chromium in the austenite } \\
\text { phase }\end{array}$ \\
\hline & boundary-value problem & ${ }^{N_{C r C}}{ }_{\nu}$ & $\begin{array}{l}\text { Number of moles of precipitated carbide } \\
\text { per molo of alloy }\end{array}$ \\
\hline$c_{0}$ & $\begin{array}{l}\text { Initial concentration of carbon in } \\
\text { steel, ppm }\end{array}$ & $\mathrm{P}$ & $\begin{array}{l}\text { Number of carbide particles per unit vol- } \\
\text { ume of alloy; i.e., } P^{-1}=4 \pi R_{s}^{3} / 3\end{array}$ \\
\hline $\mathrm{C}_{\text {eq }}$ & $\begin{array}{l}\text { Concentration of carbon in austenite } \\
\text { phase in equilibrium with carbide } \\
\text { phase, ppm }\end{array}$ & $\mathrm{R}_{\mathrm{o}}$ & Radius of a spherical carbide particle, $\mathrm{cm}$ \\
\hline $\mathrm{C}_{\mathrm{Na}}$ & $\begin{array}{l}\text { Concentration of carbon in sodium, } \\
\text { ppm }\end{array}$ & $\mathrm{R}_{\mathrm{s}}$ & $\begin{array}{l}\text { Radius of equivalent sphere surrounding } \\
\text { a carbide particle, } \mathrm{cm} \\
\text { Time, sec }\end{array}$ \\
\hline $\mathrm{C}_{\mathrm{Na}}^{\text {sat }}$ & $\begin{array}{l}\text { Solubility value for carbon in } \\
\text { sodium, ppm }\end{array}$ & $t_{f}$ & Exposure time in sodium, sec \\
\hline$c_{s}$ & $\begin{array}{l}\text { Concentration of carbon at the } \\
\text { sodium-steel interface, ppm }\end{array}$ & $\mathrm{I}$ & Temperature, ${ }^{\circ} \mathrm{K}$ \\
\hline$c_{s s}^{\gamma}$ & $\begin{array}{l}\text { Concentration of carbon in the } \\
\text { austenite phase of an austenitic } \\
\text { stainless steel, ppm }\end{array}$ & $\begin{array}{l}\mathrm{X} \\
\text { Greek } \\
\text { Letters } \\
\end{array}$ & Distance from alloy surface, $\mathrm{cm}$ \\
\hline$C_{s s}^{\text {sat }}$ & $\begin{array}{l}\text { Solubility value for carbon in } \\
\text { austenitic stainless steel, ppm }\end{array}$ & $\beta$ & $\begin{array}{l}\text { Ratio of particle radius } R_{o} \text { to radius of } \\
\text { equivalent sphere surrounding the particle, } \\
\text { i.e., } R_{o} / R_{s}\end{array}$ \\
\hline$C_{s s}^{T}$ & $\begin{array}{l}\text { Total carbon concentration (carbon } \\
\text { in austenite plus carbon in carbide) } \\
\text { in an austenitic stainless steel, ppm }\end{array}$ & r & Austenite phase in the steel \\
\hline$\overline{\mathrm{c}}$ & $\begin{array}{l}\text { Time-average carbon concentration } \\
\text { in austenite phase, ppm }\end{array}$ & $\nu$ & $\begin{array}{l}\text { Dimensionless variable, } \mathrm{X} /\left(4 \mathrm{D}_{\mathrm{C}} \mathrm{t}\right)^{1 / 2} \\
\text { Atom ratio of carbon to chromium in the } \\
\text { carbide, e.g., } 6 / 23 \text { for the } \mathrm{Cr}_{23} \mathrm{C}_{6} \text { carbide }\end{array}$ \\
\hline$\overline{\mathrm{C}}(\mathrm{t})$ & $\begin{array}{l}\text { Average carbon concentration in } \\
\text { austenite phase for a given time, ppm }\end{array}$ & $\tau_{\mathbf{n}}$ & $\left(\lambda_{n}^{2} D_{C}\right)^{-1}$ \\
\hline$D_{C}$ & $\begin{array}{l}\text { Diffusion coefficient for carbon in } \\
\text { the austenite matrix, } \mathrm{cm}^{2} / \mathrm{sec}\end{array}$ & & \\
\hline$D_{C r}$ & $\begin{array}{l}\text { Diffusion coefficient for chromium } \\
\text { in the austenite matrix, } \mathrm{cm}^{2} / \mathrm{sec}\end{array}$ & 1 & \\
\hline
\end{tabular}




\author{
A GENERALIZED METHOD OF \\ COMPUTING CARBON-DIFFUSION PROFILES \\ IN AUSTENITIC STAINLESS STEELS \\ EXPOSED TO A SODIUM ENVIRONMENT
}

by

\author{
R. B. Snyder, K. Natesan, \\ and T. F. Kassner
}

\begin{abstract}
Numerous experimental observations on the carburizationdecarburization behavior of austenitic stainless steels in hightemperature flowing sodium have been reported; however, quantitative predictions of carbon diffusion in the steels under specific environmental conditions have been difficult. A mathematical analysis for the process has been developed that incorporates (1) the thermodynamic and kinetic information for carbon in the alloys, (2) the thermal-mechanical treatment of the material (solution annealed versus cold worked) that influences the microstructure, and (3) the carbon concentration in sodium and its dependence on sodium-system parameters. Carbon concentration-distance profiles in Types 304 and 316 stainless steel were generated as a function of time, temperature, and carbon concentration in sodium and compared with experimental data.

The analysis was used to evaluate the carburizationdecarburization behavior of Type 316 stainless steel fuel cladding exposed to sodium and to develop carbon-diffusion profiles in Type 304 stainless steel intermediate-heat-exchanger piping upon exposure to primary- and secondary-system sodium for periods to $30 \mathrm{yr}$.
\end{abstract}

\title{
I. INTRODUCTION
}

The austenitic stainless steels used for the fuel cladding, in-core structural components, piping, valves, and the intermediate heat exchanger in sodium-cooled fast breeder reactors are subjected to a variety of environmental conditions that limit their performance and reliability. Most of the available mechanical-property data on Liquid Metal Fast Breeder Reactor ( $L M F B R$ ) materials have been obtained in air or inert-gas environments under simple loading conditions. In comparison, limited data have been generated in either the liquid-sodium or fast-neutronenvironment, 
and a knowledge of the integrated effect of the sodium and irradiation environments on the mechanical behavior at high temperatures is particularly lacking. ${ }^{1}$ At present, only irradiation effects are being incorporated into the property data used in the design of core components. ${ }^{2-4}$ For out-of-core components that have a design life of 20-30 yr, large extrapolations of mechanical-property data, obtained in air and inert-gas environments, are required. Furthermore, the influence of the time- and temperaturedependent migration of carbon and nitrogen in the materials that results from exposure to flowing sodium has not been considered. Environmental effects have essentially been avoided in the ASME Boiler and Pressure Vessel Code Case 1331-6 for elevated-temperature nuclear-component design ${ }^{5}$ because of insufficient mechanical-property data in sodium and the absence of adequate procedures for incorporating the mechanical-property changes that arise from compositional variations in the materials ciuring the service life of a component.

Numerous observations on carburization and decarburization of austenitic stainless steels in high-temperature flowing sodium have been made, ${ }^{6-10}$ and the importance of the carbon concentration of the steels in relation to the microstructural stability ${ }^{1-13}$ and the mechanical properties ${ }^{7,10,14-22}$ is well recognized. However, quantitative predictions of carbon diffusion in the materials and of the mechanical behavior under different service conditions have been difficult. In the present report, a mathematical analys is has been developed to obtain carbon concentrationdistance profiles in austenitic. stainless steels as a function of time, temperature, and carbon concentration in sodium. The analysis is based upon (a) thermodynamic and kinetic information for carbon in the steels, (b) the thermal-mechanical history of the material that influences the microstructure, and (c) the sodium-system parameters and operating conditions that determine the carbon concentration in sodium. This analysis, coupled with mechanical-property data being generated in ongoing programs, where the major variables are the composition, time, temperature, and metallurgical condition of the material, will provide a quantitative basis for the incorporation of isodium effects into ASME codes and Reactór Researchand Development (RRD) standards and the reby reduce the uncertainty in the design of various reactor components.

\section{CARBON-DIFFUSION ANALYSIS}

A. Development of Diffusion Relations

Carburization and decarburization of austenitic stainless steels $\mathrm{ir}_{\text {- }}$ volve the diffusion of carbon in the austenite matrix, accompanied by the precipitation or dissolution of the $(\mathrm{Cr}, \mathrm{Fe})_{23} \mathrm{C}_{6}$ carbide. The carburization process is somewhat analogous to the internal oxidation of a reactive metal in a noble-metal matrix, which has been the subject of experimental and 
theoretical investigations. ${ }^{23-29}$ The major difference between the two processes is that all reactive metal in a noble-metal matrix is converted to oxide, whereas only a fraction of the chromium present in the steel reacts to form carbide during carburization, and this amount increases with an increase in carbon potential of the sodium. A direct application of the internal-oxidation-rate equations to the carburization process without incorporating these modifications would grossly underestimate the thickness and overestimate the carbide volume fraction and total carbon content of the precipitate zone for any reaction time. The mathematical formalism for internal oxidation must therefore be modified to represent the process more closely; however, the diffusion equations become more complex and a closed-form analytical solution cannot be obtained, even for simple boundary and initial conditions. Therefore, a computer is required to obtain a numerical solution to the problem. In view of the relatively. low diffusivity of carbon in austenitic stainless steels between 400 and $800^{\circ} \mathrm{C}$ and the turbulent flow conditions in the sodium, the transfer of carbon across the liquid-boundary layer is not considered important in the overall carburizationdecarburization process.

For one-dimensional diffusion of carbon accompanied by carbide precipitation, Fick's second law for the diffusion of carbon and chromium can be written as

$$
\frac{\partial\left(N_{C}+\nu N_{C r} C_{\nu}\right)}{\partial t}=D_{C} \frac{\partial^{2} N_{C}}{\partial X^{2}}
$$

and

$$
\frac{\partial\left(N_{C r}+N_{C r C_{v}}\right)}{\partial t}=D_{C r} \frac{\partial^{2} N_{C r}}{\partial X^{2}}
$$

When chromium and carbon in austenite form the $(\mathrm{Cr}, \mathrm{Fe})_{23} \mathrm{C}_{6}$ mixed carbide by the reaction

$$
\mathrm{Cr}_{(\gamma)}+\frac{6}{23} \mathrm{C}_{(\gamma)}=\frac{1}{23} \mathrm{Cr}_{23} \mathrm{C}_{6} \text { (in mixed carbide) }
$$

the relationship between the chromium and carbon concentrations in austenite in equilibrium with the carbide can be expressed as

$$
\mathrm{N}_{\mathrm{Cr}}=\mathrm{A}-\mathrm{B} \ln \mathrm{N}_{\mathrm{C}}
$$

where $A$ and $B$ are constants that a re evaluated from carbon activityconcentration data for $\mathrm{Fe}-\mathrm{Cr}-8$ wt \% Ni alloys at various temperatures. 
With the use of Eq. 3 and the substitution of the variable $\eta=$ $\mathrm{X} /\left(4 \mathrm{D}_{\mathrm{C}} \mathrm{t}\right)^{1 / 2}$, the partial differential equations (Eqs. 1 and 2) can be converted into the ordinary differential equation

$$
-\frac{B}{N_{C}} \frac{d N_{C}}{d \eta}-\frac{1}{\nu} \frac{d N_{C}}{d \eta}=\frac{B}{2 \eta} \frac{D_{C r}}{D_{C}} \frac{d^{2}\left(\ln N_{C}\right)}{d \eta^{2}}+\frac{1}{2 \nu \eta} \frac{d^{2} N_{C}}{d \eta^{2}} \text {. }
$$

This equation was solved numerically by Hamming's modified predictorcorrector method ${ }^{30}$ for $\mathrm{N}_{\mathrm{C}}$ in terms of $\eta$ using semi-infinite boundary conditions

$$
N_{C}=N_{C}^{S} \text { for } \eta=0
$$

and

$$
N_{C}=N_{C}^{i} \text { for } \eta=\infty
$$

for uniform initial carbon concentrations in the steel $\mathrm{N}_{\mathrm{C}}^{\mathrm{i}}$ and for various surface carbon concentrations $\mathrm{N}_{\mathrm{C}}^{\mathrm{S}}$. It was found that Eq. 4 could be simplified to

$$
\frac{d^{2} N_{C}}{d \eta^{2}}+\frac{2 B \nu \eta}{N_{C}} \frac{d N_{C}}{d \eta}=0
$$

without affecting the results because of the negligible contribution from the second and third terms in Eq. 4. The Lutal carbon concentration in the steel [carbon in the austenite $\mathrm{N}_{\mathrm{C}}$ plus the carbon in the $(\mathrm{Cr}, \mathrm{Fe})_{23} \mathrm{C}_{6}$ carbide] was obtained as a function of position, for any diffusion time, from solutions to Eq. 7 and the relationships between $\mathrm{N}_{\mathrm{C}}$ and the total carbon content of the alloy given in Appendix A.

The above analysis is applicable to carburization and decarburization of an austenitic stainless steel in which the initial and surface carbon concentrations exceed the solubility limit in the material. Under decarburizing conditions in a sodium environment, in which the surface carbon concentration in the alloy can fall below the solubility value, carbon diffusion through the single-phase austenite can be described by an established solution to Fick's second law

$$
N_{C}=N_{C}^{S}+\left(N_{C}^{O}-N_{C}^{S}\right) \text { erf } \eta
$$

where $\mathrm{N}_{\mathrm{C}}^{\mathrm{O}}$ is an iterative constant.* The incorporation of Eqs. 7 and 8 into the computer program, described in Appendix C, along with the coupling

\footnotetext{
*In a single-phase material, $\mathrm{N}_{\mathrm{C}}^{\circ}$ in $\mathrm{Eq} .8$ is the initial concentration of the solute element diffusing out of the alloy. During decarburization of an austenitic stainless steel, the composition of the austenite (e.g., carbon and chromium concentrations) changes in the two-phase (austenite plus carbide) region in the vicinity of $\gamma / \gamma$ plus carbide interface. For this situation, a nonphysical value for $N_{C}^{O}$ allows the carbon concentration $\mathrm{N}_{C}$ and the flux $D_{C} \partial N_{C} / \partial X$ at the $\gamma / \gamma$ plus carbide interface obtained from $E_{q}$. 8 , for the single-phase region, and that from Eq. 7, for the two-phase region, to attain the same respective values so that the requirement for a singular carbon activity at the interface is fulfilled.
} 
condition at the $\gamma / \gamma$ plus carbide interface, made it possible to generate carbon concentration-distance profiles for both carburizing and decarburizing situations.

\section{B. Thermodynamic and Kinetic Input Parameters}

The diffusion relations in Sec. A above express the driving force for carbon migration in the material in terms of carbon-concentration differences and the self-diffusion coefficient in the austenite phase, rathcr than changes in the total carlun concentration and the effective diffusion coefficient.* Both types of information can be used to generate carbondiffusion profiles in austenitic stainless steels. However, the former approach is applicable to a wide range of temperatures and carbon levels in the material, whereas the latter is restricted to specific conditions because of limited data for the functional dependence of the effective diffusion coefficient on both temperature and carbon level in the steel.

Appendix A presents the relevant carbon-diffusion data for Types 304 and 316 stainless steel and the necessary information on carbon solubility, carbon activity-concentration relationships, and austenite-carbide phase equilibria used in the analysis. Appendix B discusses data for the solubility of carbon in sodium and factors that influence the carbon concentration in sodium contained in austenitic stainless steel systems.

\section{RESULTS AND DISCUSSION}

A. Comparison of Calculated and Experimental Carbon-diffusion Profiles in Austenitic Stainless Steels

To determine the validity of the solutions to the diffusion relations using the thermodynamic and kinetic input data given in Appendix A, carbon concentration-distance profiles were calculated for different times, temperatures, and initial and surface carbon concentrations in the materials for comparison with available experimental data. Figures'l-3 compare carbon-diffusion profiles in Type 316 stainless steel reported by Thorley et al. ${ }^{31}$ after $3864-, 4368-$, and $8760-\mathrm{hr}$ exposures to sodium at $650^{\circ} \mathrm{C}$ with calculated curves.

Andrews et al. ${ }^{22}$ reported carbon-diffusion profiles in Types 304 and 316 stainless steel after exposure of the materials to a high-carbon sodium environment at $650^{\circ} \mathrm{C}$ for up to $\sim 5400 \mathrm{hr}$. The surface carbon concentration in steels ranged between 3.08 and $3: 8 \mathrm{wt} \%$, in which the predominant carbide was the $(\mathrm{Cr}, \mathrm{Fe})_{7} \mathrm{C}_{3}$ type. Similarly, surface carbon

*The effective diffusion coefficient for carbon in stainless steel is obtained from experimentally determined carbon concentration-distance profiles using the solution to Fick's second law that is applicable only to diffusion in a single-phase material in the absence of second-phase formation. 


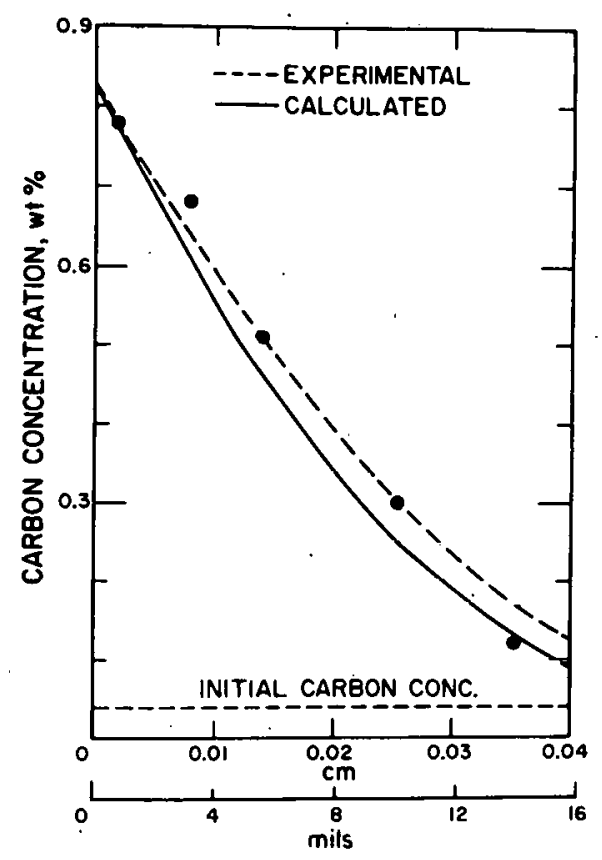

PENETRATION DISTANCE

Fig. 1

Comparison of Experimental ${ }^{31}$ and Calculated Carbon-diffusion Profiles for Type 316 Stainless Steel after Exposure to Flowing Sodium for $3864 \mathrm{hr}$ at $650^{\circ} \mathrm{C}$. Neg. No. MSD-58558.

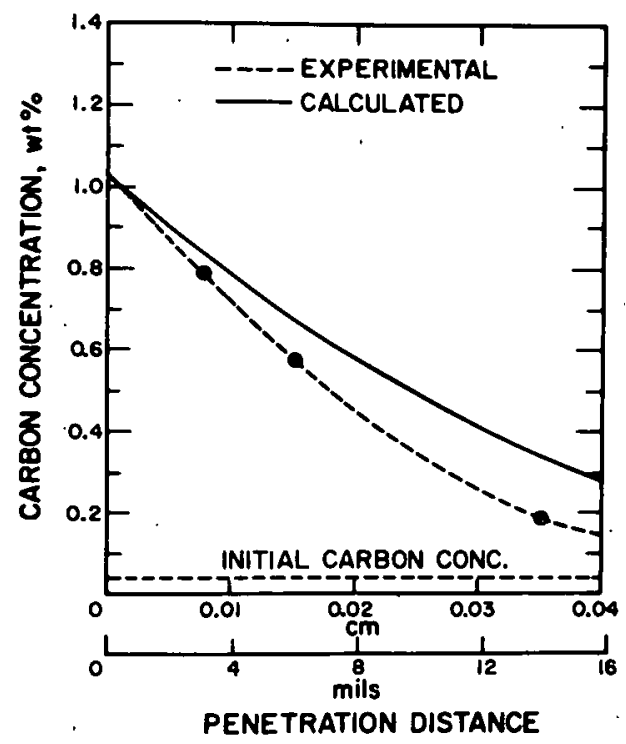

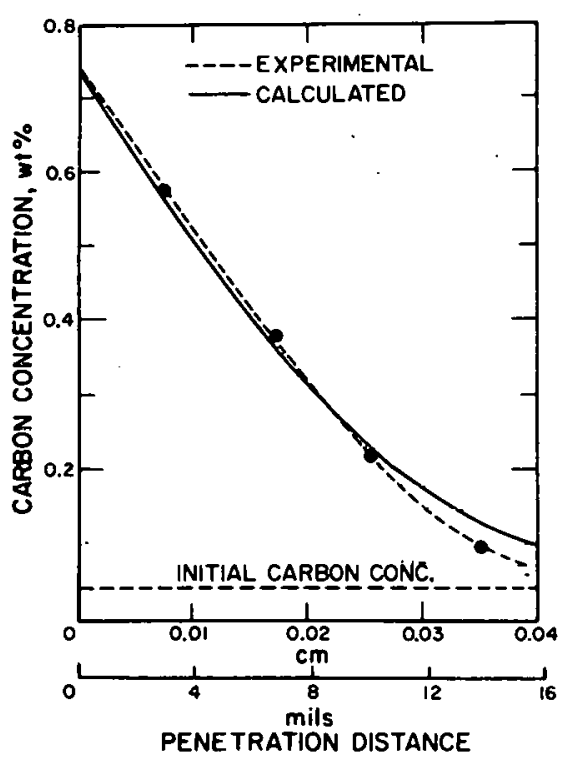

Fig. 2

Comparison of Experimental ${ }^{31}$ and Calculated Carbon-diffusion Profiles for Type 316 Stainless Steel after Exposure to Flowing Sodium for 4368 hr at $650^{\circ} \mathrm{C}$. Neg. No. MSD -58557 .

Fig. 3

Comparison of Experimental ${ }^{31}$ and Calculated Carbon-diffusion Profiles for Type 316 Stainless Steel after Exposure to Flowing Sodium for $8760 \mathrm{hr}$ at $650^{\circ} \mathrm{C}$. Neg. No. MSD-58558. 
concentrations in Type 304 stainless steel varied from 2.7 wt $\%$ at $538^{\circ} \mathrm{C}$ to $4.4 \mathrm{wt} \%$ at $871^{\circ} \mathrm{C}$ in the capsule-diffusion experiments in carbon-saturated sodium reported by Anderson and Sneesby. ${ }^{32}$ The diffusion profiles obtained in these studies cannot be compared with calculated curves, since our analysis is only applicable to carbon concentrations in the steel below $1.0 \mathrm{wt} \%$, in which the predominant carbide is the $(\mathrm{C} . \mathrm{r}, \mathrm{Fe})_{23} \mathrm{C}_{6}$ type. Nishio and Shimokawa ${ }^{33}$ determined carbon concentration profiles in Type 304 stainless steel at temperatures between 650 and $830^{\circ} \mathrm{C}$ by using a ${ }^{14} \mathrm{C}$ tracer and sectioning technique. The maximum diffusion times in this study ranged from $330 \mathrm{hr}$ at $650^{\circ} \mathrm{C}$ to $\sim 15 \mathrm{hr}$ at $830^{\circ} \mathrm{C}$, and carbon diffusion occurred predominantly along high-diffusivity paths (e.g., grain boundaries). A comparison of the results from this work with our analysis is not meaningful, since the latter is based upon volume diffusion of carbon in the materials and longer diffusion times.

B. Influence of Time, Temperature, and Carbon Concentration in Sodium on Calculated Carbon-diffusion Profiles in Austenitic Stainless Steels

Figures 4 and 5 show carbon concentration-distance profiles in $20 \%$ cold-worked Type 316 stainless steel after $1000-$ and 4000-hr exposures, respectively, to sodium containing 0.017 ppm carbon for temperatures between 550 . and $700^{\circ} \mathrm{C}$. The extent of decarburization increases with

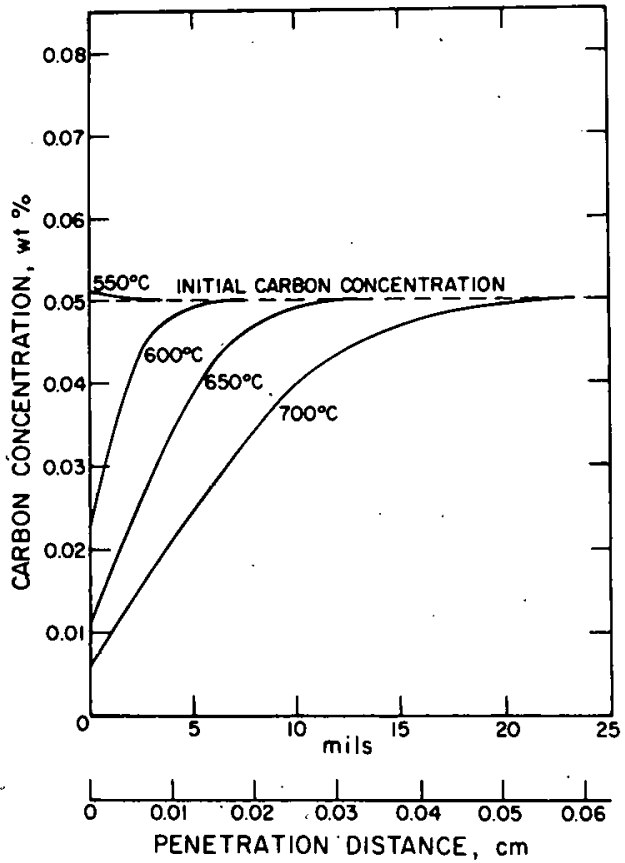

Fig. 4

Effect of T emperature on Carbon ConcentrationDistance Profiles in 20\% Cold-worked Type 316 Stainless Steel after 1000-hr Exposure to Sodium Containing $0.017 \mathrm{ppm}$ Carbon. Neg. No. MSD-58560.

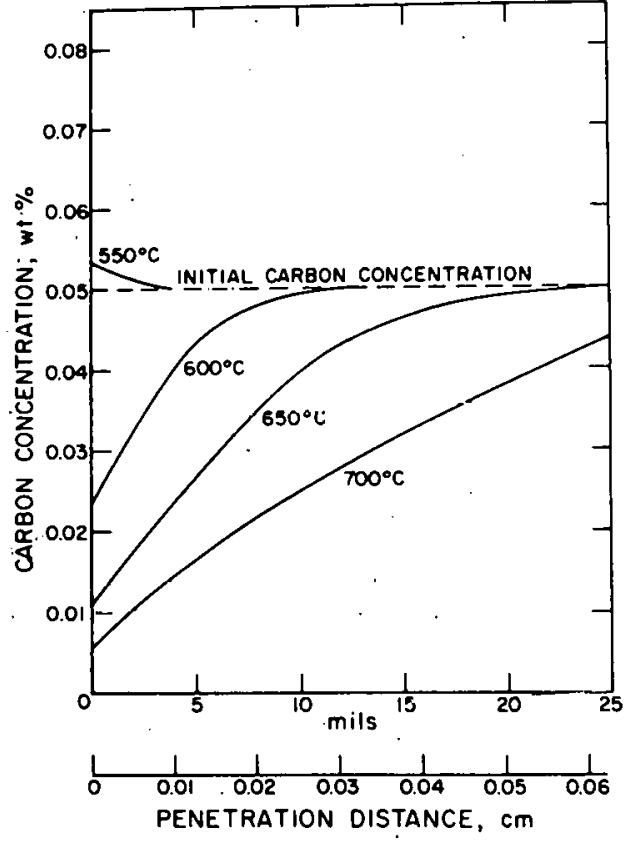

Fig. 5

Effect of Temperature on Carbon ConcentrationDistance Profiles in 20\% Cold-worked Type 316 Stainless Steel after 4000 -hr Exposure to Sodium Containing $0.017 \mathrm{ppm} \mathrm{Carbon.} \mathrm{Neg.} \mathrm{No.}$ MSD-5856]. 
an increase in exposure time and temperature, whereas the degree of carburization at $550^{\circ} \mathrm{C}$ is minimal. Profiles obtained for solution-annealed Typc 316 stainless steel were essentially the same under these conditions. Figure 6 shows the influence of the carbon concentration of the sodium in the range from 0.01 to $0.1 \mathrm{ppm}$ on the surface carbon concentration and the carbon profiles in solution-annealed Type 304 stainless steel after $10,000 \mathrm{hr}$ at $650^{\circ} \mathrm{C}$. Depending upon the carbon concentration in sodium, carburization or decarburization of the material can occur. Figures 7 and 8 show the effect of the initial carbon content of the steel in the 0.02-0.08 wt \% range on the diffusion profiles after 10,000-hr exposure to sodium containing $0.13 \mathrm{ppm}$ carbon at 550 and $700^{\circ} \mathrm{C}$, respectively. The carbon penetration depth is relatively insensitive to the initial carbon concentration over the range representative of commercial-grade Types $304 \mathrm{~L}$ and 304 stainless steel.

To obtain a general understanding of the influence of time, temperature, carbon concentration in sodium, and the thermal-mechanical treatment. on the carburization-decarburization behavior of Types 304 and 316 stainless steel, carbon concentration-distance profiles were computed for a number of temperatures between 400 and $800^{\circ} \mathrm{C}$. The results were used to construct the carbon concentration-penetration-temperature diagrams shown in Figs. 9-14. The influence of increasing the exposure time for solutionannealed Type 304 stainless steel in sodium containing 0.017 and $0.13 \mathrm{ppm}$ carbon can be seen from a comparison of Figs. 9 and 10 and Figs. 11 and 12 , respectively. Figures 10 and 12 illustrate the effect of the carbon concentration in sodium on the carburization-decarburization behavior for an exposure time of $10,000 \mathrm{hr}$. Types 304 and 316 stainless steel can be compared from the results in Figs. 12 and 13, whereas the influence of the thermalmechanical treatment (solution-annealed versus cold-worked) in Type 316 stainless steel can be seen from Figs. 13 and 14. In these figures, the crossover temperature between carburization and decarburization for a steel with an initial carbon content of 0.05 wt \% increases from 550 to $680^{\circ} \mathrm{C}$ as the carbon concentration in sodium increases from 0.017 to $0.13 \mathrm{ppm}$. The variation of the carbon concentration at the surface of the steel with temperature is shown in the plane corresponding to zero penetration in the material. For a given carbon concentration in sodium, which implies a time-invariant carbon activity at the surface of the steel, the increase in the carbon concentration at the steel surface with exposure time at temperatures below $600^{\circ} \mathrm{C}$ is due to a metastable equilibrium between the aus tenite and carbide phases. The underlying factors that lead to this condition in the material are discussed in Appendix A. In Figs. 9-14, line A indicates the variation of the region of maximum carburization, and line $B$ represents the penetration depth for the transition between the single-phase austenite and the two-phase austenite plus carbide mixture.

A carbon concentration in sodium of $0.017 \mathrm{ppm}$ was used in the analysis because this value results in decarburization of the steels from 


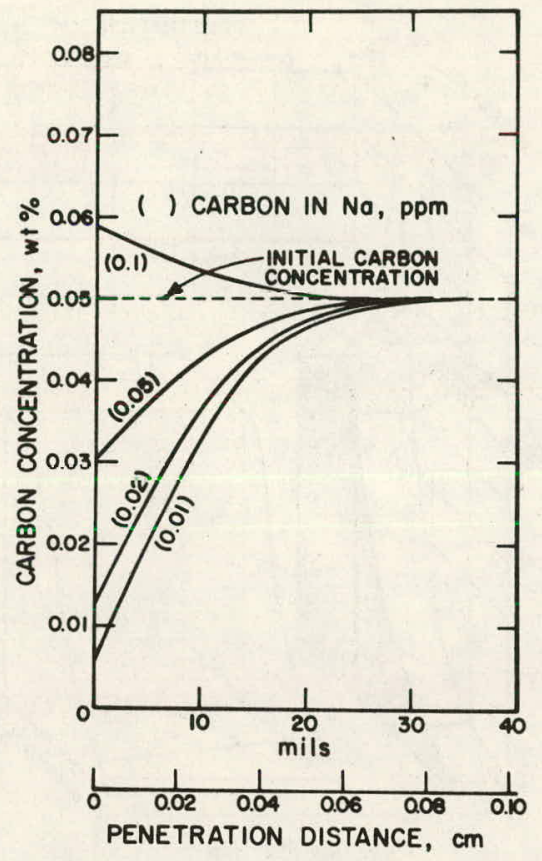

Fig. 6

Carburization and Decarburization Profiles in Solution-annealed Type 304 Stainless Steel after $10,000 \mathrm{hr}$ at $650^{\circ} \mathrm{C}$ for Various Carbon Levels in Sodium. Neg. No. MSD-58559.

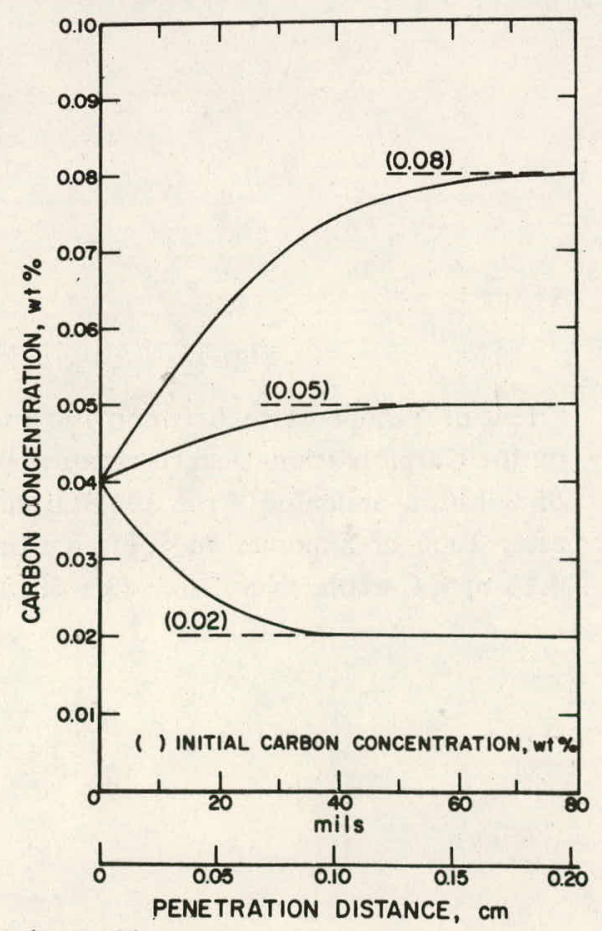

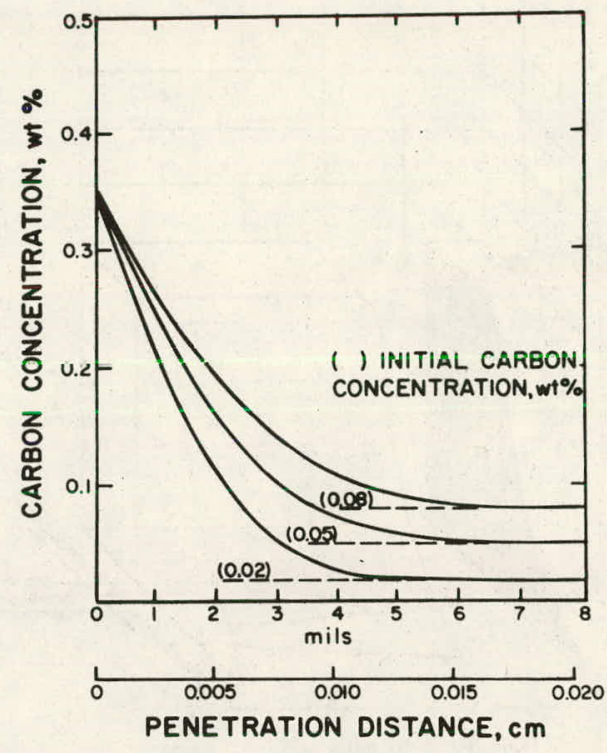

Fig. 7

Effect of Initial Carbon Content of Solutionannealed Type 304 Stainless Steel on the Carbon-diffusion Profiles after 10,000-hr Exposure to Sodium Containing $0.13 \mathrm{ppm}$ Carbon at $550^{\circ} \mathrm{C}$. Neg. No. MSD-58562.

Fig. 8

Effect of Initial Carbon Content of Solutionannealed Type 304 Stainless Steel on the Carbon-diffusion Profiles after 10,000-hr Exposure to Sodium Containing $0.13 \mathrm{ppm}$ Carbon at $700^{\circ} \mathrm{C}$. Neg. No. MSD -58563 . 


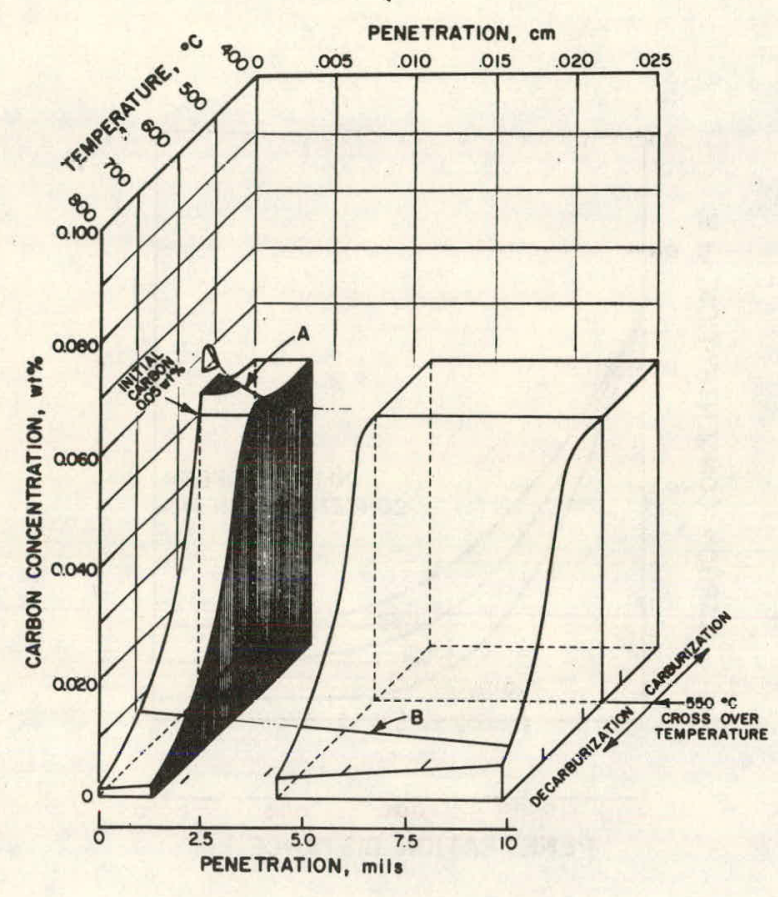

Fig. 9

Effect of Temperature between 400 and $800^{\circ} \mathrm{C}$ on the Carburization-Decarburization Behavior of Solution-annealed Type 304 Stainless Steel after 4000-hr Exposure to Sodium Containing 0.017 ppm Carbon. Neg. No. MSD-58239.

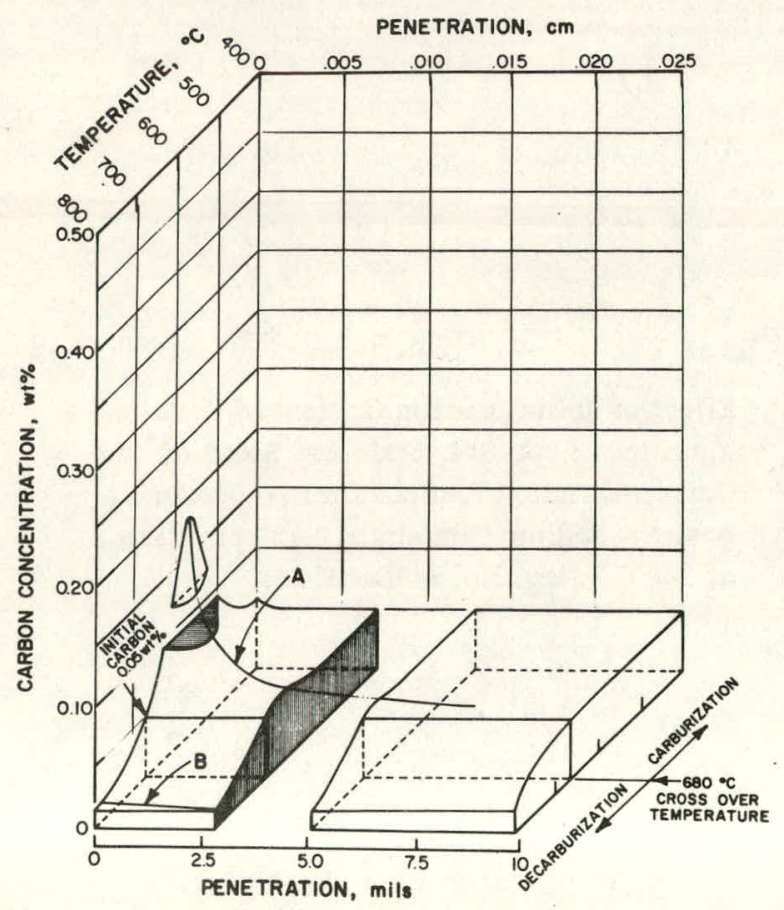

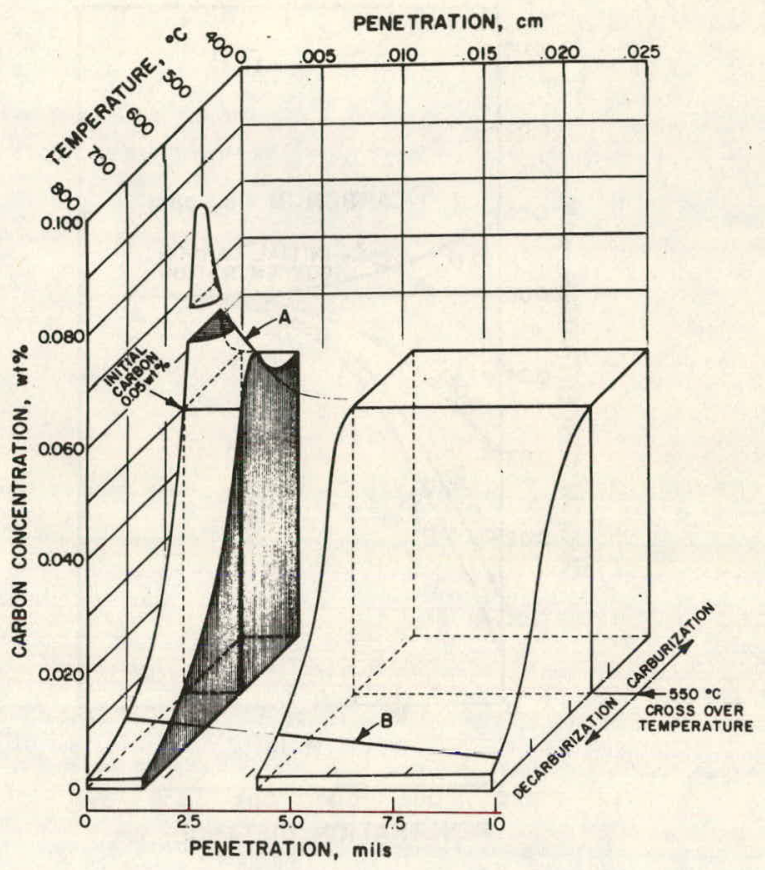

Fig. 10

Effect of Temperature between 400 and $800^{\circ} \mathrm{C}$ on the Carburization-Decarburization Behavior of Solution-annealed Type 304 Stainless Steel after 10,000-hr Exposure to Sodium Containing 0.017 ppm Carbon. Neg. No. MSD-58240.

Fig. 11

Effect of Temperature between 400 and $800^{\circ} \mathrm{C}$ on the Carburization-Decarburization Behavior of Solution-annealed Type 304 Stainless Steel after 1000-hr Exposure to Sodium Containing 0.13 ppm Carbon. Neg. No. MSD-58237. 


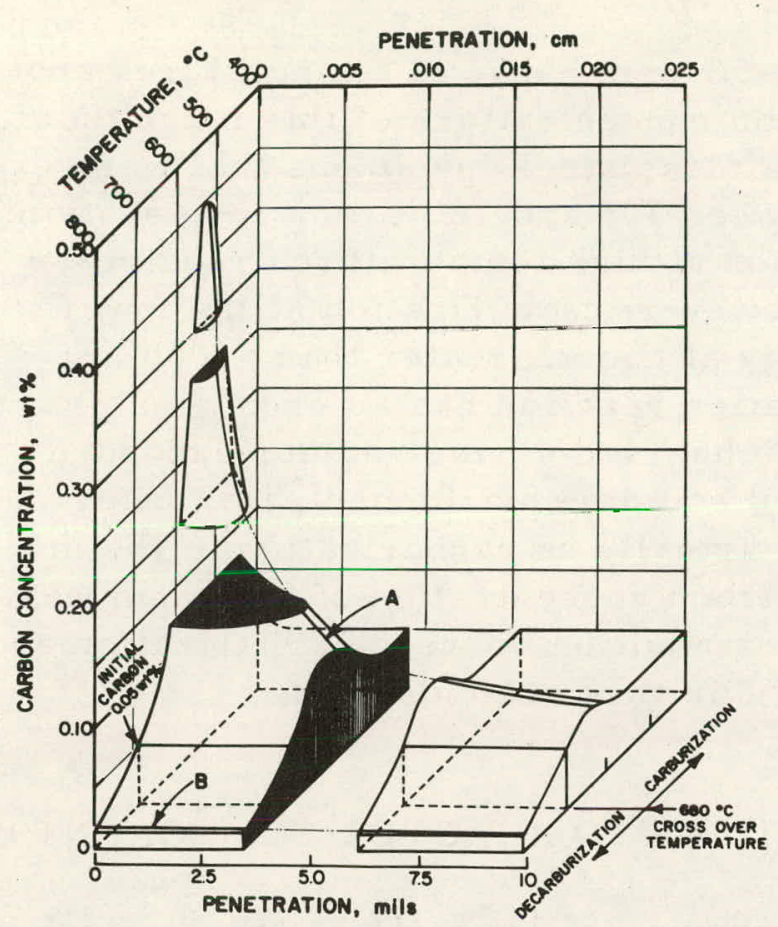

Fig. 12

Effect of Temperature between 400 and $800^{\circ} \mathrm{C}$ on the Carburization-Decarburization Behavior of Solution-annealed Type 304 Stainless Steel after 10,000-hr Exposure to Sodium Containing 0.13 ppm Carbon. Neg. No. MSD-58238.

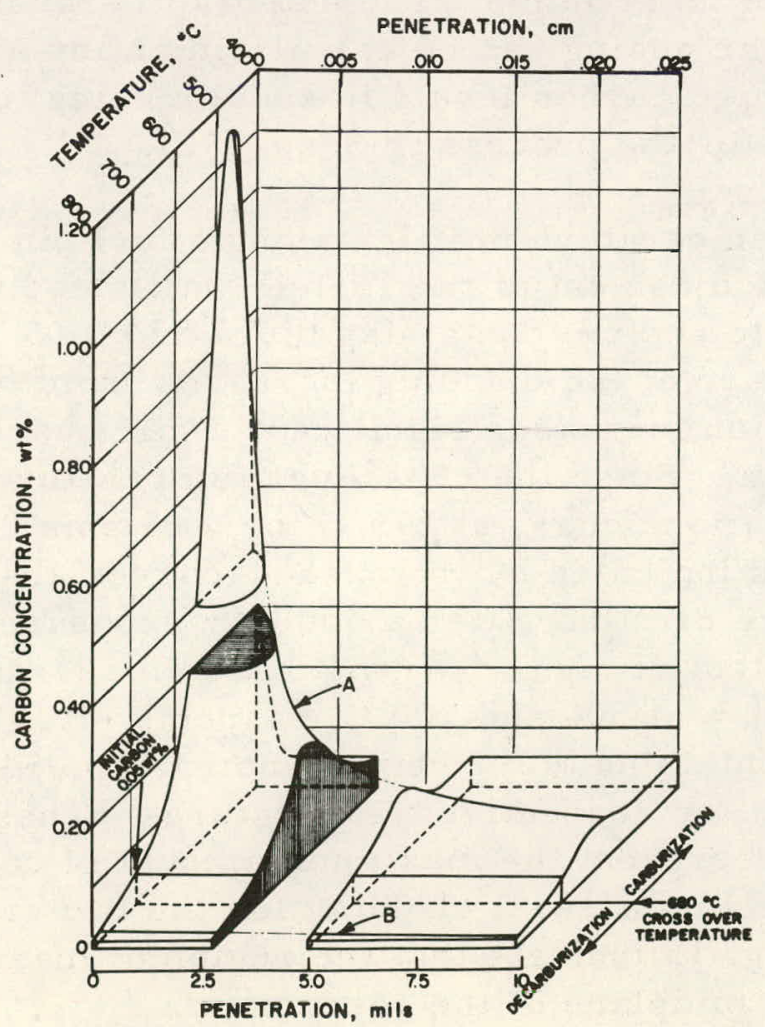

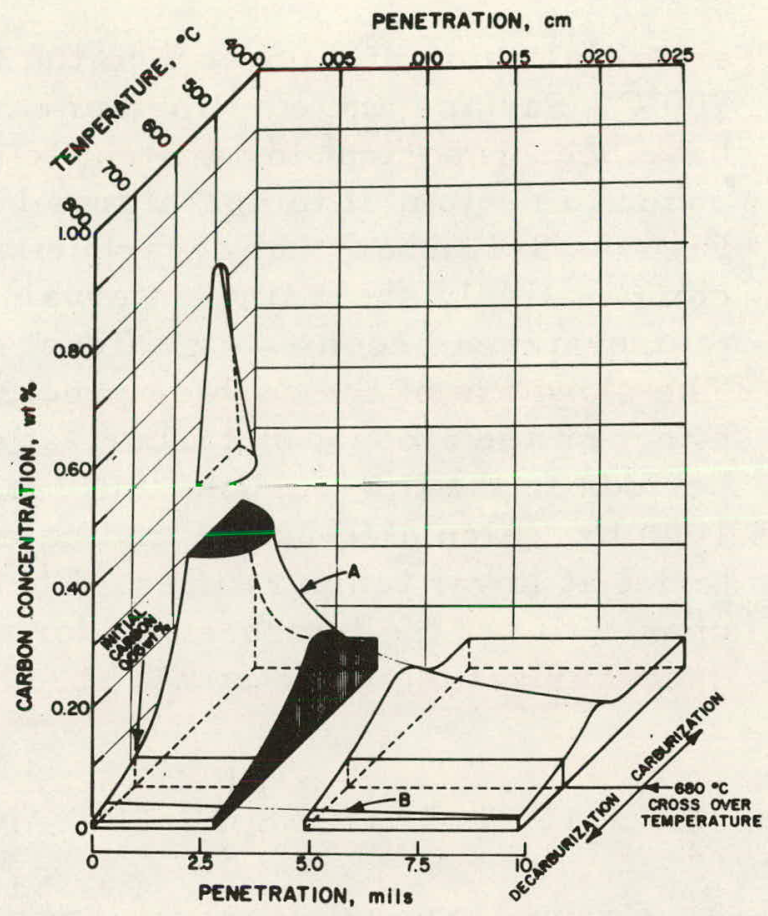

Fig. 13

Effect of Temperature between 400 and $800^{\circ} \mathrm{C}$ on the Carburization-Decarburization Behavior of Solution-annealed Type 316 Stainless Steel after 10,000-hr Exposure to Sodium Containing 0.13 ppm Carbon. Neg. No. MSD-58564.

Fig. 14

Effect of Temperature between 400 and $800^{\circ} \mathrm{C}$ on the Carburization-Decarburization Behavior of 20\% Cold-worked Type 316 Stainless Stee1 after 10,000-hr Exposure to Sodium Containing 0.13 ppm Carbon. Neg. No. MSD-58565. 
an initial value of 0.05 wt $\%$ to the $30-50-\mathrm{ppm}$ range at temperatures above $700^{\circ} \mathrm{C}$. Surface and equilibrium carbon concentrations of this magnitude have been reported ${ }^{8}$ for austenitic stainless steel specimens that were exposed to sodium at temperatures between 705 and $760^{\circ} \mathrm{C}$ in a loop system. Figures 9-14 show that decarburization at high temperatures requires a comparatively short time interval; however, carburization at the lower temperatures becomes significant only at times greater than $\sim 4000 \mathrm{hr}$. The slowness of the carbide precipitation reaction has an even greater effect on the amount of carburization observed during shorter exposure periods in the low-carbon (0.017-ppm) sodium environment; i.e., after $1000 \mathrm{hr}$, calculated curves indicated virtually no carburization of the material at lower temperatures. The carbon concentration of $0.13 \mathrm{ppm}$ was chosen to set the temperature for the transition between carburization and decarburization of the steels at $\sim 680^{\circ} \mathrm{C}$ in these calculations.

\section{APPLICATIONS OF THE ANALYSIS TO REACTOR COMPONENTS}

A. Carburization-Decarburization Behavior of Type 316 Stainless Steel Fuel Cladding

Type 316 stainless steel fuel cladding will be exposed to flowing sodium at temperatures above $600^{\circ} \mathrm{C}$ in FFTF, U.S. Demonstration Reactor, and bypass flow subassemblies in EBR-II. The axial temperature profile for the fuel cladding in these systems will depend upon the sodium inlet temperature $\left(370-440^{\circ} \mathrm{C}\right)$ as well as the maximum temperature for the cladding that occurs at the top of the fuel column. The extent of carburization or decarburization of the fuel cladding can be calculated at any axial position along the fuel pin for specified carbon levels in sodium using the mathematical formalism developed for the process in Secs. I-III.

Figure 15 shows two axial temperature profiles along a fuel pin and the corresponding average carbon content of the 15-mil-wall cladding after $1000-$ and $5000-\mathrm{hr}$ exposures to sodium containing 0.017 and $0.05 \mathrm{ppm}$ carbon. As the maximum temperature of the cladding increases from 600 to $700^{\circ} \mathrm{C}$, the extent of decarburization increases significantly for a carbon concentration in sodium of $0.017 \mathrm{ppm}$. Since the crossover temperature between carburization and decarburization occurs at $615^{\circ} \mathrm{C}$ for 0.05 ppm carbon in sodium, only carburization is indicated by the dashed curves that correspond to the lower temperature profile. After a 5000-hr exposure, the steel, with an initial carbon content of 0.05 wt $\%$, will have an average carbon content of 0.065 and 0.025 wt $\%$ at 500 and $700^{\circ} \mathrm{C}$, respectively. The corresponding values for sodium containing $0.017 \mathrm{ppm}$ carbon are 0.054 and 0.004 wt $\%$ carbon in the material at the respective temperatures. These carbon concentrations in the steel represent the maximum amount of carburization or decarburization of the 15-mil-wall cladding for the two carbon levels in sodium. The curves in Fig. 15 indicate that the region of maximum carburization occurs near the midplane of the core. 

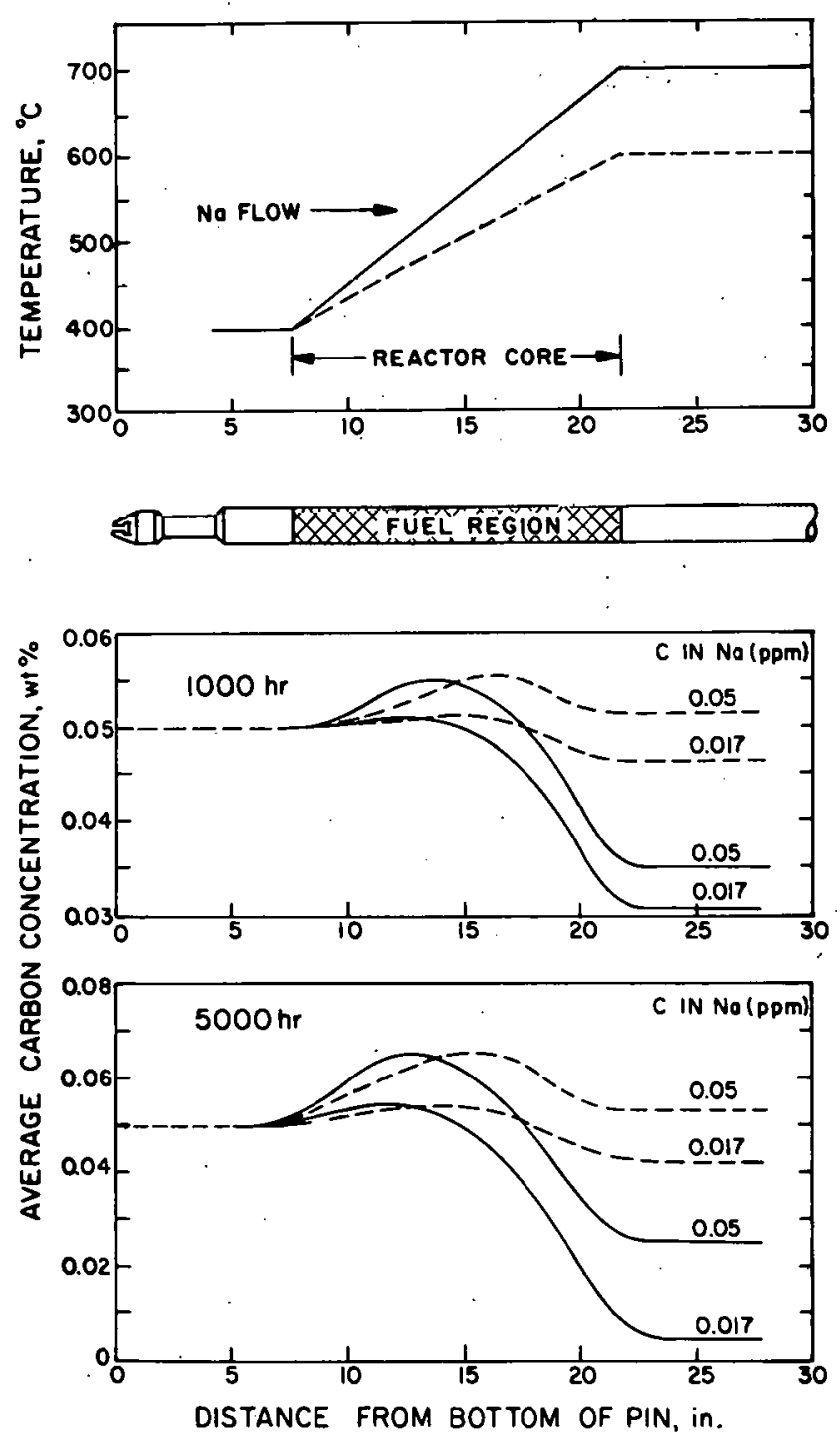

Fig. 15

Relationship between the Axial Temperature Profile for a Fuel Pin and the Average Carbon Content of the 15-milwall 20\% Cold-worked Type 316 Stainless. Steel Cladding after 1000- and 5000-hr Exposure to Sodium Containing 0.017 and 0.05 ppm Carbon. Neg. No. MSD-58629.
Figure 16 shows carbon concentration-distance profiles across the cladding wall at 500 , 600 , and $700^{\circ} \mathrm{C}$ after a $5000-\mathrm{hr}$ exposure to sodium containing 0.05 ppm carbon. As the temperature increases from 500 to $700^{\circ} \mathrm{C}$, the surface carbon concentration in the steel decreases from 0.33 to 0.015 wt $\%$ and the depth of penetration increases from $3 \mathrm{mils}$ to the entire cross section.

The information in Table I summarizes the mass of carbon that is either gained or lost by a segment of fuel cladding $1 \mathrm{~cm}$ long ( $0.5 \mathrm{~g}$ of steel) at temperatures between 400 and $700^{\circ} \mathrm{C}$ for two carbon levels in sodium and exposure times of 1000 and $5000 \mathrm{hr}$. In many instances, the changes in the carbon concentration for an 0.5-g sample of the fuel cladding are within the accuracy limits of the combustion method using a low-carbon analyzer (i.e., $\pm 20 \mu \mathrm{g}$ of carbon for a small number of samples). For the purpose of comparing measured carbon concentrations in the fuel cladding from various subassemblies with the results of this type of analysis, the actual carbon content of the primary sodium should be determined by exposing iron-base alloy foils to the coolant in an out-ofcore loop, such as the equilibration

module located on the Radioactive Sodium Chemistry Loop (RSCL) ${ }^{34}$ at EBR-II, and correlating the carbon concentrations in the materials with the carbon activity. ${ }^{35}$ From a knowledge of the carbon concentration in sodium and the axial temperature profile along the fuel pin, curves similar to those in Fig. 15 can be calculated for specific exposure times to identify regions that have undergone a significant change in carbon content for chemical analysis. This approach will minimize the number of samples required to obtain an accurate carbon profile along the fuel pin. Although the relationship between the carbon content of austenitic stainless steels and the 
mechanical behavior in a fast-neutron environment has not been established, it may have an important bearing on the performance of fuel cladding and other core components.
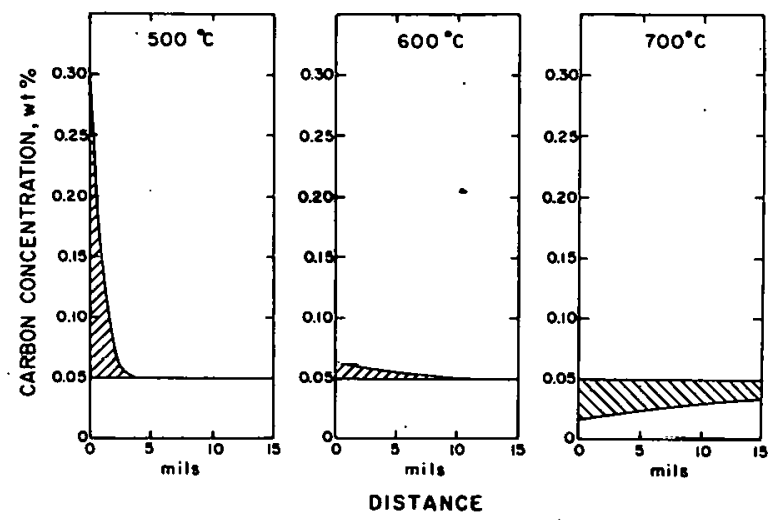

Fig. 16

Carbon Concentration-Distance Profiles across the $20 \%$ Cold-worked Type 316 Stainless Steel Cladding Wall at 500,600 , and $700^{\circ} \mathrm{C}$ after 5000 -hr Exposure to Sodium Containing 0.05 ppm Carbon. Neg. No. MSD-58633.

TABLE I. Mass of Carbon Gained or Lost from a $1-\mathrm{cm}$ Length of $20 \%$ Cold-worked Type 316 Stainless Steel Fuel Claddinga as a Function of Temperature and Carbon Concentration in Sodium after an Exposure of 1000 and $5000 \mathrm{hr}$

\begin{tabular}{crrrrr}
\hline & $\begin{array}{c}0.017 \mathrm{ppm} \text { Carbon } \\
\text { in Sodiumb }\end{array}$ & & \multicolumn{2}{c}{$\begin{array}{c}0.05 \text { ppm Carbon } \\
\text { in Sodiumb }\end{array}$} \\
\cline { 2 - 3 } \cline { 5 - 6 } Temperature, ${ }^{\circ} \mathrm{C}$ & $1000 \mathrm{hr}$ & $5000 \mathrm{hr}$ & & $1000 \mathrm{hr}$ & $5000 \mathrm{hr}$ \\
\hline 700 & -108 & -241 & & -80 & -128 \\
650 & -51 & -113 & & -25 & -50 \\
600 & -18 & -39 & & +8 & +18 \\
550 & 0 & +1 & & +25 & +63 \\
500 & +5 & +21 & & +23 & +81 \\
450 & +1 & +16 & & +6 & +46 \\
400 & 0 & +2 & & 0 & +7 \\
\hline
\end{tabular}

a An initial carbon concentration of 0.050 wt \% was used for the 0.23 -in. $-O D$ by $15-$ mil-wall fuel cladding.

$b_{\mu} g$ of Carbon gained (t) or lost (-) by the fuel cladding.

B. Carburization of Type 304 Stainless Steel Intermediate Heat-exchanger Piping by Primary-and Secondary-system Sodium

An intermediate heat exchanger (IHX), located within the reactor containment structure, is used to transfer heat from the radioactive sodium that flows through the core of the reactor to a secondary nonradioactivesodium system that includes the steam generator. The IHX, constructed of Type 304 stainless steel, has a maximum operating temperature slightly below the mixed-mean outlet temperature of the primary sodium. The 
mixed-mean outlet temperatures for experimental test facilities such as EBR-II, Dounreay, Rapsodie, and FFTF and demonstration reactors such as the U.S. Demonstration Plant, BN-350, Fermi, MONJU, PFR, PHENIX, and SNR range between 454 and $566^{\circ} \mathrm{C} .{ }^{36-41}$. The commercial LMFBR's are expected to have an outlet temperature as high as $620^{\circ} \mathrm{C} .{ }^{41}$

The carbon concentration of the sodium in the primary system in these reactors will depend upon the system operating temperatures and operating conditions that introduce carbon-bearing materials into the primary system, as discussed in Appendix B. The carbon concentration of the sodium in the secondary system will depend on the operating temperature and the material used to construct the steam generator (e.g., Fe-2.25 w.t $\% \mathrm{Cr}-$ 1 wt \% Mo alloy versus Incoloy 800). The carburization behavior of the IHX must therefore be examined in terms of the carbon concentrations of the sodium in both the primary and secondary heat-transport systems.

The present analysis can be used to evaluate the carburization behavior of Type 304 stainless steel IHX piping at temperatures between 443 and $600^{\circ} \mathrm{C}$ for up to $30 \mathrm{yr}$. Carbon concentrations in sodium of 0.05 and $0.13 \mathrm{ppm}$, which may be representative of the primary and secondary systems, were used in generating the carbon concentration-distance profiles at various temperatures shown in Figs. 17-21. The calculated average

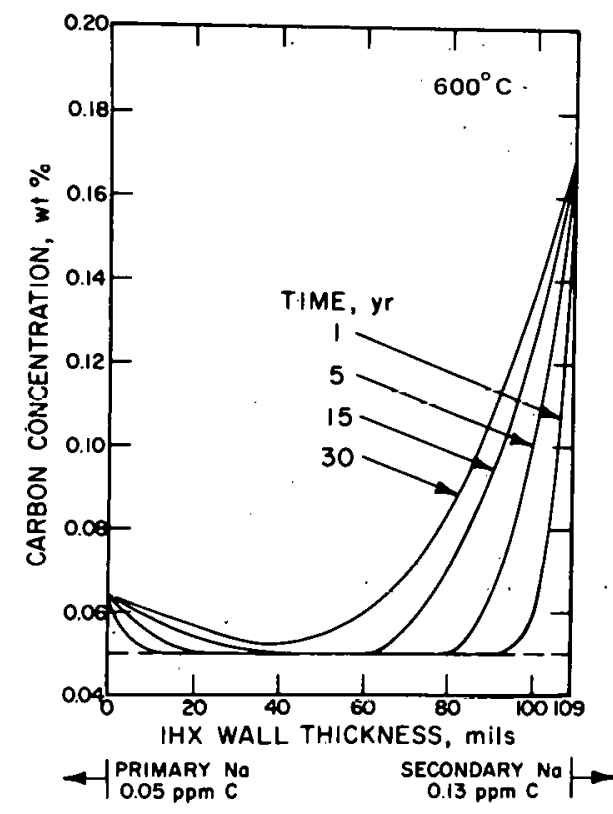

Fig. 17

Carbon Concentration-Distance Profiles across Type 304 Stainless Steel IHX Piping after Exposure to Primary- and Secondary-system Sodium Containing 0.05 and $0.13 \mathrm{ppm}$ Carbon, Respectively, for up to $30 \mathrm{yr}$ at $600^{\circ} \mathrm{C}$. Neg. No. MSD-58568.

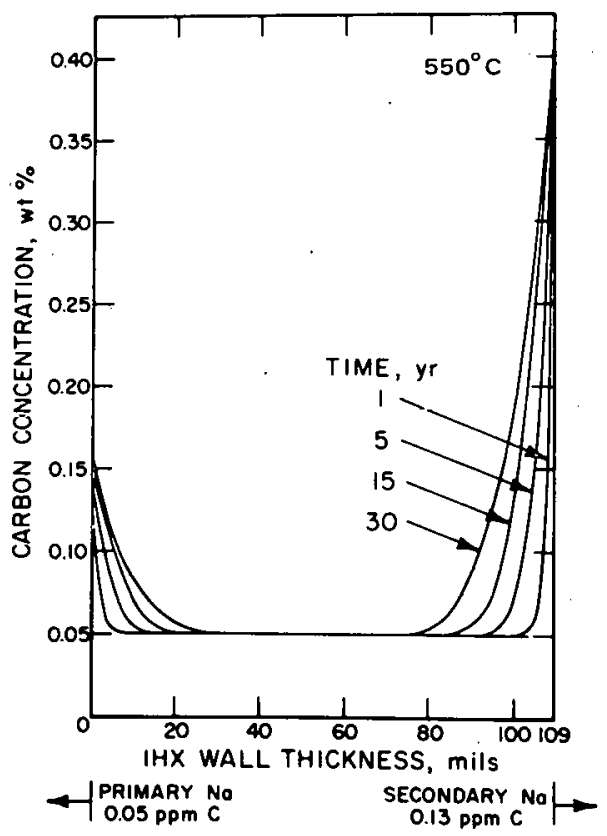

Fig. 18

Carbon Concentration-Distance Profiles across Type 304 Stainless Steel IHX Piping after Exposure to Primary- and Secondary-system Sodium Containing 0.05 and $0.13 \mathrm{ppm}$ Carbon, Respectively, for up to $30 \mathrm{yr}$ at $550^{\circ} \mathrm{C}$. Neg. No. MSD-58569. 


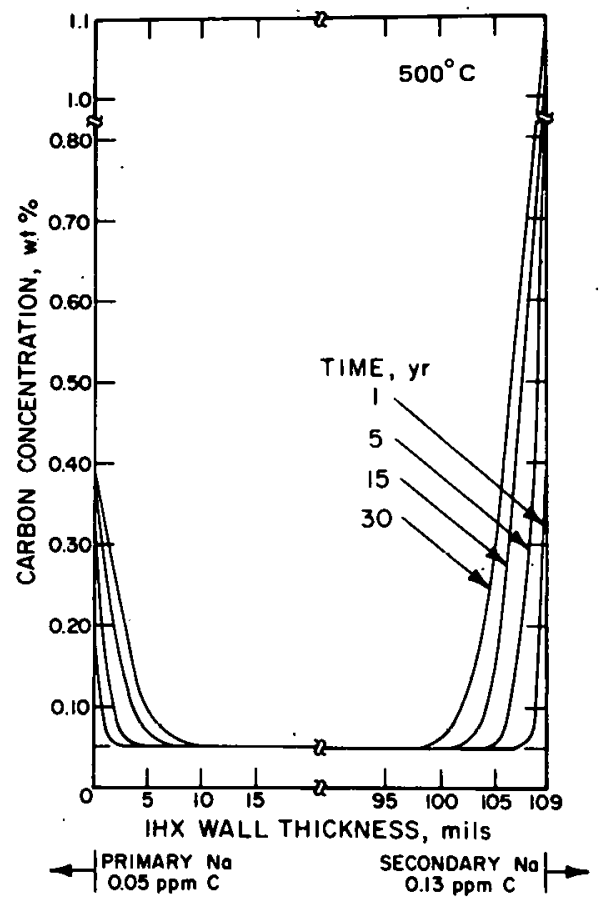

Fig. 19

Carbon Concentration-Distance Profiles across Type 304 Stainless Steel IHX Piping after Exposure to Primary- and Secondary-system Sodium Containing 0.05 and $0.13 \mathrm{ppm}$ Carbon, Respectively, for up to $30 \mathrm{yr}$ at $500^{\circ} \mathrm{C}$. Neg. No. MSD-58582.

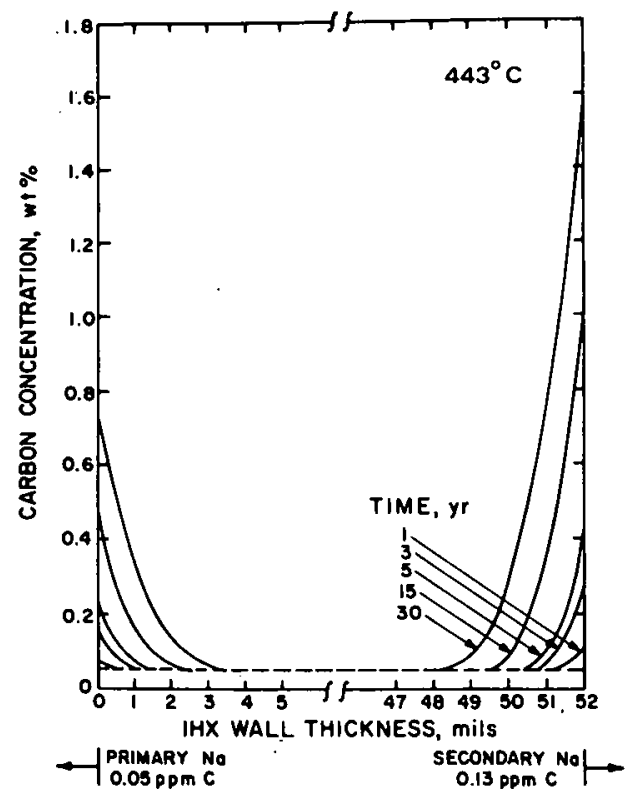

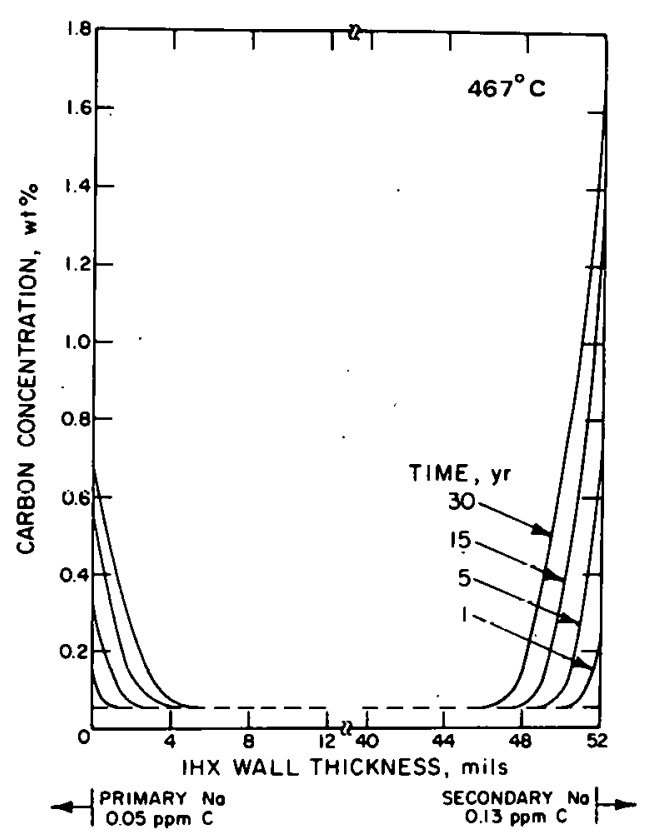

Fig. 20

Carbon Concentration-Distance Profiles across Type 304 Stainless Steel IHX Piping after Exposure to Primary- and Secondary-system Sodium Containing 0.05 and 0.13 ppm Carbon, Respectively, for up to $30 \mathrm{yr}$ at $467^{\circ} \mathrm{C}$. Neg. No. MSD-58583.

Fig. 21

Carbon Concentration-Distance Profiles across Type 304 Stainless Steel IHX Piping after Exposure to Primary- and Secondary-system Sodium Containing 0.05 and 0.13 ppm Carbon, Respectively, for up to $30 \mathrm{yr}$ at $443^{\circ} \mathrm{C}$. Neg. No. MSD-58570. 
carbon concentrations in sections of the piping in the region of the sodiumsteel interface are given in Table II. As shown in Figs. 17-21, the carbon concentration at the surface of the steel increases and the depth of penetration decreases as the operating temperature is lowered, for any time.

Below $\sim 500^{\circ} \mathrm{C}$, the carbon concentration at the surface of the material increases with an increase in exposure time, as discussed in Appendix A. The temperatures in Figs. 20 and 21 correspond to the maximum temperature of the IHX and a secondary-sodium-system vent-line pipe, respectively, in EBR-II. Piping from the vent line was removed, sectioned, and analyzed for carbon after 6 yr of ieaclur operation, during which the material was at $443^{\circ} \mathrm{C}$ for $\sim 30 \%$ of the time and at $\sim 300^{\circ} \mathrm{C}$ for the remainder. The carbon concentrations in a section 3 mils. from the surface and at the center of the pipe wall were 0.13 and 0.06 wt \%, respectively. ${ }^{42}$ Calculated carbon concentrations for the first $3 \mathrm{mils}$ of the material after exposure to sodium for periods of 3 and $5 \mathrm{yr}$ at $443^{\circ} \mathrm{C}$ ( Table II) are similar in magnitude (e.g., $0.1 \mathrm{wt} \%$ ) for a carbon concentration in sodium of $0.13 \mathrm{ppm}$. Although a comparison of this type cannot be used to establish quantitatively the validity of the mathematical analysis, it indicates that. reasonable values are obtained from the calculations.

TABLE II. Calculated Average Carbon Concentrationsa for Sections of Type 304 Stainless Steel Pipingb after Exposure to Sodium Containing 0.05 and $0.13 \mathrm{ppm}$ Carbon at Temperatures between 443 and $600^{\circ} \mathrm{C}$ for up to $30 \mathrm{yr}$

\begin{tabular}{|c|c|c|c|c|c|c|c|c|c|c|c|}
\hline \multirow{3}{*}{$\begin{array}{c}\text { Time, } \\
\text { yr }\end{array}$} & \multirow{3}{*}{$\begin{array}{c}\text { Distance from } \\
\mathrm{Na} / \text { Steel } \\
\text { Interface, mils }\end{array}$} & \multicolumn{5}{|c|}{0.05 ppm Carbon in Sodium } & \multicolumn{5}{|c|}{$0.13 \mathrm{ppm}$ Carbon in Sodium } \\
\hline & & \multicolumn{5}{|c|}{ Temperature, ${ }^{\circ} \mathrm{C}$} & \multicolumn{5}{|c|}{ Temperature, ${ }^{\circ} \mathrm{C}$} \\
\hline & & 443 & 467 & 500 & 550 & 600 & 443 & 467 & 500 & 550 & 600 \\
\hline \multirow[t]{3}{*}{1} & $0-3$ & 0.052 & 0.059 & 0.081 & 0.094 & 0.061 & 0.058 & 0.076 & 0.133 & 0.200 & 0.137 \\
\hline & $3-6$ & 0.050 & 0.050 & $0.050^{\circ}$ & 0.053 & 0.055 & 0.050 & 0.050 & 0.050 & 0.063 & 0.091 \\
\hline & $6-10$ & 0.050 & 0.050 & 0.050 & 0.050 & 0.051 & 0.050 & 0.050 & 0.050 & 0.050 & 0.062 \\
\hline \multirow[t]{3}{*}{3} & $0-3$ & 0.065 & 0.090 & 0.130 & 0.117 & 0.062 & 0.075 & 0.155 & 0.270 & 0.267 & 0.151 \\
\hline & $3-6$ & 0.050 & 0.050 & 0.051 & 0.067 & 0.060 & 0.050 & 0.050 & 0.056 & 0.122 & 0.123 \\
\hline & $6-10$ & 0.050 & 0.050 & 0.050 & 0.053 & 0.053 & 0.050 & 0.050 & 0.050 & 0.062 & 0.081 \\
\hline \multirow[t]{3}{*}{5} & 0.3 & 0.081 & 0.123 & 0.171 & 0.125 & 0.063 & 0.122 & 0.231 & 0.393 & 0.297 & 0.155 \\
\hline & $3-6$ & 0.050 & 0.050 & 0.054 & 0.082 & 0.061 & 0.050 & 0.050 & 0.063 & 0.168 & 0.133 \\
\hline & $6-10$ & 0.050 & 0.050 & 0.050 & 0.058 & 0.056 & 0.050 & 0.050 & 0.050 & 0.079 & 0.099 \\
\hline \multirow[t]{3}{*}{15} & $0-3$ & 0.164 & 0.250 & 0.255 & 0.137 & 0.063 & 0.320 & 0.572 & 0.647 & 0.346 & 0.155 \\
\hline & $3-6$ & 0.050 & 0.052 & 0.096 & 0.107 & 0.062 & 0.050 & 0.062 & 0.193 & 0.228 & 0.148 \\
\hline & $6-10$ & 0.050 & 0.050 & 0.052 & 0.082 & 0.060 & 0.050 & 0.050 & 0.057 & 0.177 & 0.129 \\
\hline \multirow[t]{3}{*}{30} & $0-3$ & 0.280 & 0.370 & 0.302 & 0.143 & 0.063 & 0.617 & 0.923 & 0.757 & 0.365 & 0.156 \\
\hline & $3-6$ & 0.051 & 0.052 & 0.147 & 0.135 & 0.063 & 0.052 & 0.125 & 0.365 & 0.290 & 0.155 \\
\hline & $6-10$ & 0.050 & 0.050 & 0.067 & 0.086 & 0.061 & 0.050 & 0.050 & 0.124 & 0.219 & 0.138 \\
\hline
\end{tabular}

a Carbon concentration in wt \%.

${ }^{b}$ An initial carbon concentration of 0.05 wt $\%$ in the steel was used.

Although the calculated profiles do not result in carburization of the piping in its entire cross section under these conditions, the high carbon concentration and carbon gradient at the surface of the material can have important implications with regard to the fatigue and creep-fatigue properties. Limited data on the low-cycle fatigue behavior of Type 304 
stainless steel in "high-carbon" sodium indicated a significant reduction in the number of cycles to failure compared with tests in air and helium environments for cyclic strain levels up to $2 \% .^{22}$ The reduction of the fatigue life under carburizing conditions in a sodium environment can be rationalized in the following manner. Since it is generally known that the surface of the specimen deforms much earlier than the bulk material, the dislocation density near the surface is much higher than in the bulk of the specimen. ${ }^{43,44}$ When the amount of carbide in this region is small, the egress of dislocations is facilitated and leads to a condition in which slip is more favorable than crack initiation and propagation in the material. For high carbon concentrations in the material at the sodium-steel interface, the reverse situation occurs. Simultaneous carburization of the crack tip may also promote crack propagation. It is likely that a threshold value exists for the carbon concentration in the surface region of the steel, above which the fatigue and creep-fatigue properties deteriorate considerably. Therefore, a correlation of these properties with sodiumexposure conditions (e.g., time, temperature, and carbon concentration in sodium) should be possible.

\section{CONCLUSIONS AND FUTURE WORK}

A generalized method has been developed for computing carbondiffusion profiles in austenitic stainless steels exposed to a sodium environment. The results of the analysis showed that carbon migration in the steels is inevitable at lemperaturcs between 400 and $800^{\circ} \mathrm{C}$. The amount of carburization or decarburization is strongly dependent upon the temperature and carbon concentration in sodium, whereas the initial. carbon concentration of the material and the thermal-mechanical treatment have a lesser influence on the carbon-diffusion profiles.

A comparison of calculated and experimental carbon concentrationpenetration profiles at $650^{\circ} \mathrm{C}$ under carburizing conditions indicated reasonable agreement; however, additional experimental data are required at temperatures below $\sim 600^{\circ} \mathrm{C}$ to establish the reliability of the calculations over a wider temperature range. The analysis was used to examine the carburization-decarburization behavior of Type 316 stainless steel fuel cladding exposed to sodium and the carburization of Type 304 IHX piping for carbon concentrations in sodium that may be representative of the primary and secondary systems. A more quantitative prediction of carbon diffusionin the materials will be possible when the carbon activity of the sodium in reactor and experimental loop systems is established by the foil-equilibration method. 
Decarburization at high temperatures has a profound effect on the creep-rupture properties of the steel. Also, the amount of carburization at lower temperatures can influence the creep-fatigue properties, since crack initiation and propagation can be strongly dependent on the composition and microstructure of the material in the vicinity of the sodium-steel interface. The compositional variations due to the sodium environment will be correlated with mechanical-property changes, developed in an ongoing program, and incorporated into the present analysis to provide a quantitative basis for establishing the design and performance limits of various components that operate in a sodium environment. 


\section{APPENDIX A}

Thermodynamic, Kinetic, and Microstructural Information for Austenitic Stainless Steels

The relevant materials data used in the analysis of the carburizationdecarburization process are (1) the diffusion coefficient for carbon in the steel, (2) the activity and solubility of carbon in, and austenite-carbide phase-equilibria relations for, $\mathrm{Fe}-\mathrm{Cr}-8$ wt \% $\mathrm{Ni}$ alloys, and (3) the influence of thermal-mechanical history on the microstructure and carbideprecipitation kinetics in austenitic stainless. steels.

\section{Carbon-diffusion Data}

The diffusion of carbon in austenitic stainless steels has been determined by several investigators. Agarwala et al. ${ }^{45}$ used a residual-activity technique to measure the diffusivity of ${ }^{14} \mathrm{C}$ in Types 304,316 , and 347 stainless steel in the temperature range of $450-1200^{\circ} \mathrm{C}$. The carbon concentration in these materials was 0.08 wt $\%$ and remained essentially constant during the experiment. The contribution of grain-boundary diffusion was insignificant, as evidenced by the linear dependence of ln DC with reciprocal temperature over the entire range. The results for the three materials are summarized by the equations

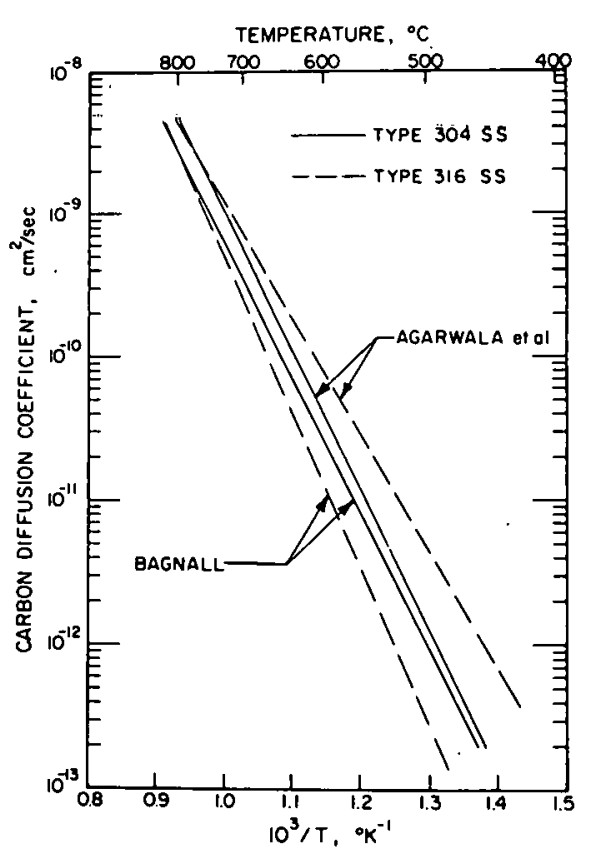

Fig. A.1

Temperature Dependence of Diffusion Coefficient for Carbon in Types 304 and 316 Stainless Steel. 45,46 Neg. No. MSD-58571.

$$
\begin{aligned}
& D_{C}^{304 S S}=6.18 \exp (-22,450 / T) \\
& D_{C}^{316 S S}=0.19 \exp (-18.820 / T)
\end{aligned}
$$

and

$D_{C}^{347 S S}=0.35 \exp (-20,200 / T)$.

Equations A.l and A.2, for Types 304 and 31.6 stainless steel, are plotted in Fig. A.l.

Bagnall ${ }^{46}$ measured the diffusivity of carbon in Types $304 \mathrm{~L}$ and $316 \mathrm{~L}$ stainless steel by exposing 3-mil-thick foils to flowing sodium at temperatures between 565 and $760^{\circ} \mathrm{C}$ for varying lengths of time under decarburizing conditions and determining the average carbon concentration in the materials by a combustion technique. A classical solution to Fick's second law was used to compute the diffusivity values. The results are summarized by the relations

$D_{C}^{304 S S}=1.75 \exp (-21,760 / T)$ 
and

$$
\mathrm{D}_{\mathrm{C}}^{316 S S}=40.9 \exp (-25,090 / \mathrm{T})
$$

which are also shown in Fig. A.1. The diffusivity values for Type 304 stainless steel are in good agreement with the data reported by Agarwala et al.; however, the values for Type 316 stainless steel are a factor of $\sim 15$ smaller at temperatures below $500^{\circ} \mathrm{C}$.

Anderson and Sneesby ${ }^{32}$ exposed foil samples of Type 304 stainless steel to carbon-saturated sodium in capsule experiments. The surface carbon concentration in the material ranged from 2.7 to 4.4 wt $\%$ at temperatures between 538 and $871^{\circ} \mathrm{C}$. The diffusion coefficients computed from the average carbon concentrations in the steel were considerably lower than the results of the other investigations. These data, which represent "effective diffusion coefficients" because of the precipitation of a large amount of carbide, are only applicable to conditions that result in high carbon concentrations in the material.

In view of the wide temperature range and the comparatively large numbers of determinations, the results of Agarwala et al. were used in our analysis of carbon diffusion in the materials exposed to a sodium environment. Additional information on the carbon diffusivity in Type 316 stainless steel will resolve the uncertainty. in the results shown in Fig. A.l and can be easily incorporated. into the analysis.

2. Carbon Activity, Solubility, and Phase-equilibria Data for Temperatures between 600 and $800^{\circ} \mathrm{C}$

When an austenitic stainless steel undergoes carburization, the concentration of chromium in the austenite decreases while that of carbon increases as the carbide: is precipitated. To obtain a quantitative description of these compositional changes for use in the computer program, mathematical expressions were developed for the activity and solubility of carbon in $\mathrm{Fe}-\mathrm{Cr}-8 \mathrm{wt} \% \mathrm{Ni}$ alloys as a function of temperature. An expression that relates the carbon concentration in the austenite phase to the total carbon content of the $\mathrm{Fe}-18 \mathrm{wt} \% \mathrm{Cr}-8 \mathrm{wt} \% \mathrm{Ni}$ alloy over a range of temperatures was also derived from austenite-carbide phase-equilibrium data.

Carbon activity-concentration relationships for $\mathrm{Fe}-\mathrm{Cr}-\mathrm{Ni}$ alloys in the composition range 0-16 wt \% Ni, 0-22 wt \% Cr, and 0.01-1.0 wt \% C were experimentally determined over the temperature range of $725-1060^{\circ} \mathrm{C}$. The results of this work are summarized by the expression ${ }^{47}$ 
$\ln a_{C}^{\mathrm{Fe}-\mathrm{Cr}-\mathrm{Ni}-\mathrm{C}}=\ln (0.048 \% \mathrm{C})+\left(0.525-\frac{.300}{\mathrm{~T}}\right) \% \mathrm{C}-1.845+\frac{5100}{\mathrm{~T}}$

$$
\begin{aligned}
& -\left(0.021-\frac{7.2 .4}{\mathrm{~T}}\right) \% \mathrm{Ni}+\left(0.248-\frac{404}{\mathrm{~T}}\right) \% \mathrm{Cr} \\
& -\left(0.0102-\frac{9.422}{\mathrm{~T}}\right) \% \mathrm{Cr}^{2} .
\end{aligned}
$$

The carbon activity-concentration relationship for an Fe-18 wt \% Cr8 wt \% Ni alloy was generated from the aboveequation and can be written as

$$
\ln \mathrm{C}_{\mathrm{s} s}^{\mathrm{T}}(\mathrm{ppm})=\mathrm{A}+\mathrm{B} \ln \mathrm{a}_{\mathrm{C}}
$$

where

$$
\begin{aligned}
& A=A_{0}+A_{1} / T+A_{2} T, \\
& B=B_{0}+B_{1} / T+B_{2} T,
\end{aligned}
$$

and

$$
\begin{array}{ll}
A_{0}=1.4 .5, & B_{0}=2.0, \\
A_{1}=-1.74 \times 10^{3}, & B_{1}=-4.52 \times 10^{2}, \text { and } \\
A_{2}=-9.84 \times 10^{-4}, & B_{2}=-5.87 \times 10^{-4}
\end{array}
$$

The solubility of carbon in stainless steel with $18 \mathrm{wt} \%$ chromium and 8-10 wt \% nickel has been investigated at temperatures between 750 and $1200^{\circ} \mathrm{C},{ }^{48-52}$ and the results were summarized in a previous paper. ${ }^{53}$ These data and more recent results for the solubility of carbon in the $\mathrm{Fe}-8$ wt $\% \mathrm{Ni}$ alloy ${ }^{47}$ were used to compute carbon-solubility values for $\mathrm{Fe}-\mathrm{Cr}-8$ wt \% $\mathrm{Ni}$ alloys as a function of temperature by the method described in Ref. 53 . The relationship between the carbon and chromium concentrations in the austenite phase at the $Y$-carbide phase boundary for any temperature is given by

$$
\operatorname{Cr}(w t \%)=A^{\prime} \ln C_{s S^{\prime}}^{\gamma}(p p m)+B^{\prime},
$$

where

$$
\begin{aligned}
& A^{\prime}=A_{3}+A_{4} / T+A_{5} T \\
& B^{\prime}=B_{3}+B_{4} / T+B_{5} T
\end{aligned}
$$


and

$$
\begin{array}{ll}
A_{3}=31.86, & B_{3}=-343.5, \\
A_{4}=-1.42 \times 10^{4}, & B_{4}=1.47 \times 10^{5}, \text { and } \\
A_{5}=-2.186 \times 10^{-2}, & B_{5}=0.232 .
\end{array}
$$

The temperature dependence of the solubility of carbon in an Fe-18 wt \% Cr8 wt $\% \mathrm{Ni}$ alloy, consistent with Eq. A.10, becomes

$$
C_{\text {Ss }}^{\text {sat }}(\mathrm{ppm})=1.088 \times 10^{7} \exp (-11,940 / \mathrm{T}) \text {. }
$$

Upon substitution of $C_{\mathrm{ppm}}^{\mathrm{sat}}$ from Eq. A.13 for $\mathrm{C}_{\mathrm{ppm}}^{\mathrm{T}}$ in Eq. A.7, the activity of carbon in the austenite at the $\gamma$-carbide phase boundary can be calculated. This value is used in the computer program to establish the transition between the single-phase austenite and the two-phase austenite plus carbide mixture during decarburization of the material, since different diffusion equations are applicable in the two regions (Eqs. 7 and 8). The carbon activity in the single-phase austenite for a given carbon concentration can be obtained from a knowledge of the carbon activity at the $Y$-carbide phase boundary and the solubility: of carbon in the steel using the relation

$$
{ }^{{ }} \mathrm{C}=\frac{C_{\text {ss }}^{\gamma}}{C_{\text {ss }}^{\text {sat }}}{ }^{\text {sat }}{ }_{C} .
$$

Since the carbon-concentration gradient in the austenite phase pro-. vides the driving force for the carburization or decarburization process, it is necessary to obtain a mathematical relationship between the carbon concentration in the austenite and the total carbon content of the $\mathrm{Fe}-18 \mathrm{wt} \% \mathrm{Cr}-$ $8 \mathrm{wt} \% \mathrm{Ni}$ alloy as a function of temperature. For this purpose, Eq. A.6 was used to generate a series of curves that relate the chromium and carbon concentrations in $\mathrm{Fe}-\mathrm{Cr}-8$ wt \% $\mathrm{Ni}$ alloys for a number of carbon activities. A plot of this type is shown in Fig. A.2 for $700^{\circ} \mathrm{C}$. Similar plots were

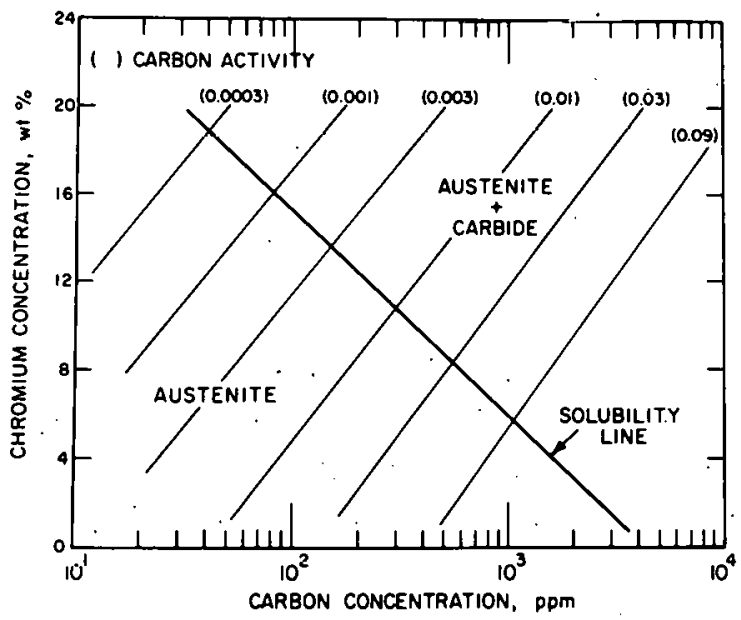

Fig. A.2

Carbon Isoactivity Lines and Solubility of Carbon in $\mathrm{Fe}-\mathrm{Cr}-8$ wt \% Ni Alloys at $700^{\circ} \mathrm{C}$. Neg. No. MSD 58572 . 
constructed for other temperatures between 600 and $1000^{\circ} \mathrm{C}$. The $Y / Y$ plus carbide phase-boundary line obtained from Eq. A.10 is also plotted in

Fig. A.2. From this figure and similar

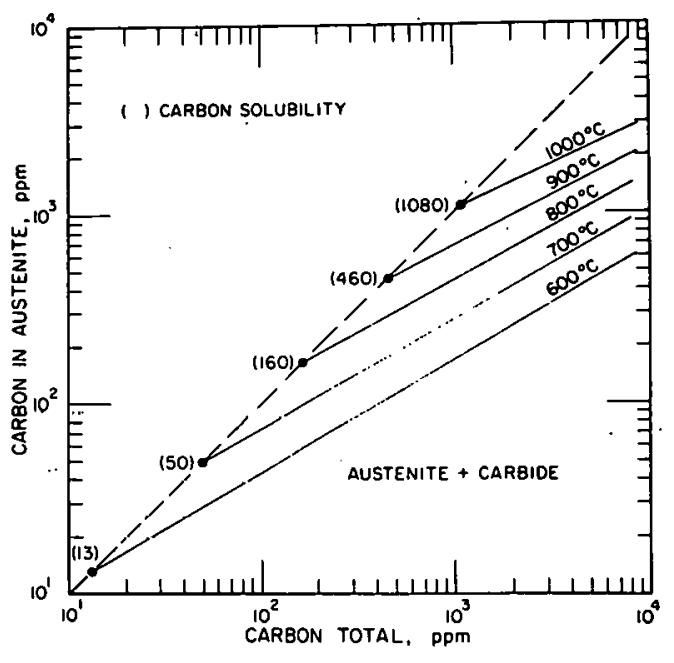

Fig. A.3

Relationship between Carbon Concentration in the Austenite Phase and Total Carbon Content of an $\mathrm{Fe}-18$ wt \% Cr$8 \mathrm{wt} \%$ Ni Alloy at Temperatures between 600 and $1000^{\circ} \mathrm{C}$. Neg. No. MSD-58573. plots at other temperatures, the relationship between the carbon concentration in the austenite and the total carbon content of an $\mathrm{Fe}-18$ wt $\% \mathrm{Cr}-8$ wt $\% \mathrm{Ni}$ alloy, shown in Fig. A.3, was constructed. For any total carbon concentration in the above alloy, the corresponding carbon concentration in the austenite phase was established from the intersection of the isoactivity line with the phase-boundary line; i:e., at a carbon activity of 0.01 , a total carbon concentration of $1100 \mathrm{ppm}$ corresponds to a carbon content in the austenite of $300 \mathrm{ppm}$ at $700^{\circ} \mathrm{C}$ : The curves in Fig. A. 3 were used to generate the following expression that relates the carbon concentration in the austenite phase to the total carbon content of the steel at any temperature in the two-phase region:

$$
\ln C_{p p m}^{Y}=A^{\prime \prime} \ln C_{p p m}^{T}+B^{\prime \prime},
$$

where

$$
\begin{aligned}
& A^{\prime \prime}=A_{6}+A_{7} / T+A_{8} T, \\
& B^{\prime \prime}=B_{6}+B_{7} / T+B_{8} T,
\end{aligned}
$$

and

$$
\begin{array}{ll}
A_{6}=1.752, & B_{6}=-7.673, \\
A_{7}=-468, & B_{7}=1553, \text { and } \\
A_{8}=-7.12 \times 10^{-4}, & B_{8}=7.93 \times 10^{-3} .
\end{array}
$$

In the single-phase region, the carbon concentration in the austenite and the total carbon content of the alloy are identical. This is indicated by the dashed line in Fig. A.3.

The equations in this section represent a self-consistent set of thermodynamic relations for the Fe-18 wt \% Cr-8 wt \% Ni austenitic steel. A change in either the carbon activity-concentration relation (Eq.A.6 or A.7) or the carbon solubility information for $\mathrm{Fe}-\mathrm{Cr}-8$ wt $\% \mathrm{Ni}$ alloys 
(Eq. A.10) would require a recalculation of the information of the type given in Fig. A.2 for several temperatures to obtain a revised plot analogous to Fig. A.3. The coefficients for Eqs. A.7-A.12 and A.15-A.17 would also have to be redetermined from the revised data and incorporated into the computer program.

3. Data for the Metastable Equilibrium between the Austenite and Carbide Phases at Temperatures between 400 and $600^{\circ} \mathrm{C}$

Since the rate of carbide precipitation decreases markedly with a decrease in temperature, a metastable equilibrium between supersaturated austenite and the carbide phase can exist at the lower temperatures. The thermal-mechanical history of the material (solution-annealed versus coldworked condition) influences the carbide-precipitation kinetics by altering the grain size of the material and the size and distribution of the carbide particles. The time and temperature dependence of precipitation of the various phases (e.g., carbides, sigma, chi, and eta) in austenitic stainless steels with different thermal-mechanical treatment is commonly reported in in the form of time-temperature-precipitation (TTP) diagrams. ${ }^{11-13}$ This type of information indicates that carbide precipitation in these materials is essentially complete within several hundred hours at temperatures above $\sim 650^{\circ} \mathrm{C}$, whereas at lower temperatures the time scale for the process extends over thousands of hours. As a result, the carbon concentration in the austenite phase is much higher than the equilibrium value; this condition leads to a decrease in the thermodynamic driving force for carburization of the steel for a given carbon concentration at the steel surface, which is established by the carbon activity in sodium. The time- and temperaturedependent carbon concentration of the austenite phase can be incorporated into our kinetic analysis of the carburization-decarburization process for steels in a sodium environment.

Nolfi et al. ${ }^{54}$ developed the following mathematical expression for the average carbon concentration in the austenite phase as a function of time $\bar{C}(t)$ during the growth or dissolution of spherical carbide particles:

$$
\bar{C}(t)=C_{o}+\frac{\left(C_{e q}-C_{o}\right) P}{1-B^{3}} \sum_{n=0}^{\infty} B_{n}^{2}\left[1-\exp \left(-\frac{t}{T_{n}}\right)\right] \text {, }
$$

where the symbols are as defined in the nomenclature. The following assumptions were made in deriving Eq. A.18: (a) A thermodynamic equilibrium exists between the carbide and the austenite phases at the particle surface; (b) the particle boundary movements are small, in comparison with the size of the particles; (c) the only driving force for the movement of both solute and solvent elements is that due to concentration gradients; i.e., precipitation-induced stresses are assumed to be negligible; and (d) the carbon-diffusion coefficient is independent of composition. 
The input parameters required for computing the average carbon concentration in the austenite from Eq. A.18 were obtained from experimental data for solution-annealed and cold-worked austenitic stainless steels. The particle radius $R_{O}$ and interparticle distance $2 R_{S}$ were obtained from photomicrographs of aged Types 304 and 316 stainless steel. Typical values for $R_{S}$ of $7.5 \times 10^{-4}$ and $5.0 \times 10^{-4} \mathrm{~cm}$ for the solution-annealed and $20 \%$-cold-worked materials, respectively, and $5 \times 10^{-5} \mathrm{~cm}$ for $R_{0}$ were used. The equilibrium carbon concentration in the austenite $C$ eq for a steel with various initial carbon contents $C_{o}$ was obtained as a function of temperature from Eq. A.15, since $C_{p p m}^{\gamma} \equiv C_{\text {eq. }}$. Values of $\bar{C}(t)$, computed for a number of times up to the desired exposure time $\left(t_{f}\right)$ at each temperature, were used in Eq. A.19 to obtain a time-average carbon concentration $\bar{C}$ for the austenite,

$$
\bar{C}=\frac{1}{t_{f}} \int_{0}^{t_{f}} \bar{C}(t) d t .
$$

Figures A. 4 and A. 5 show the temperature dependence of the equilibrium and time-average carbon concentrations in the austenite phase of

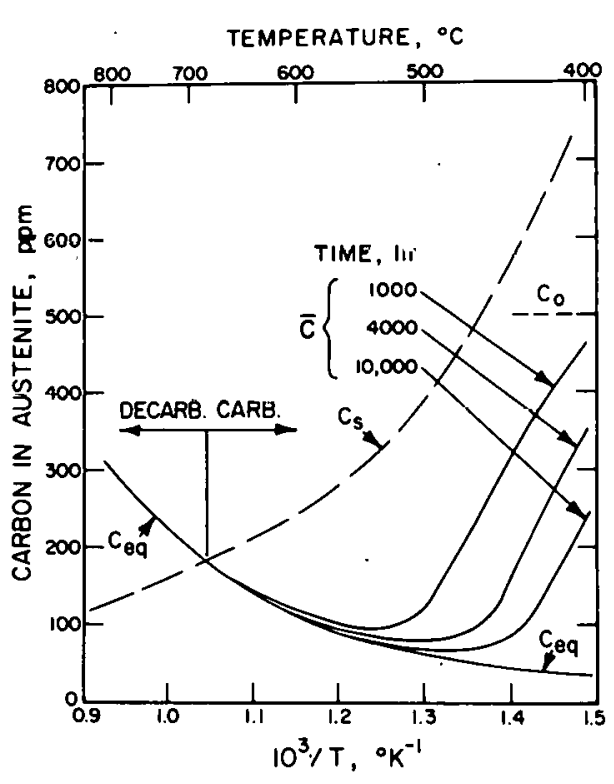

Fig. A.4. Effect of Temperature on Concentration of Carbon in the Austenite Phase at the Sodium-Steel Interface $C_{S}$ and That within the Material $\bar{C}$ for Annealing Times of 1000,4000 , and $10,000 \mathrm{hr}$ for Solution-annealed Type 316 Stainless Steel with an Initial Carbon Concentration of 0.05 wt \%. (A carbon concentration of $0.13 \mathrm{ppm}$ in the sodium was used to obtain the variation of $\mathrm{C}_{\mathrm{S}}$ with temperature.) Neg. No. MSD-58574.

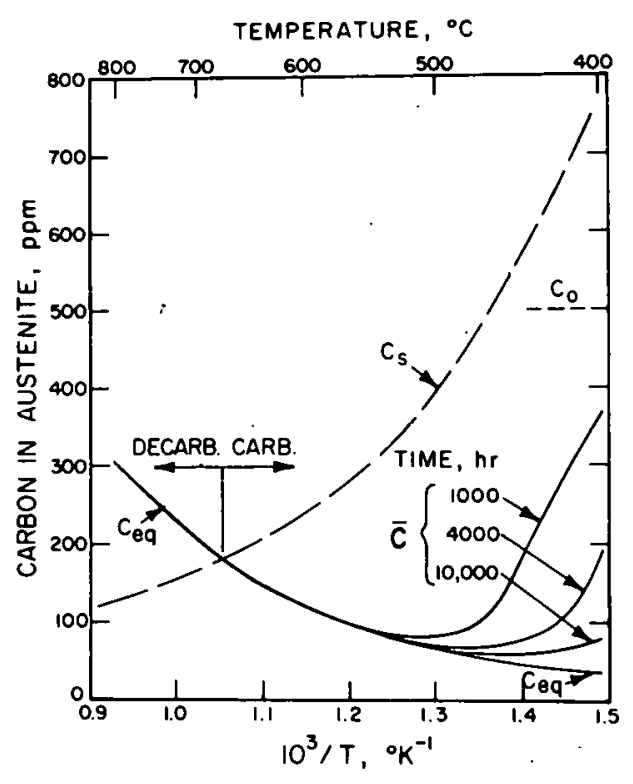

Fig. A.5. Effect of Temperature on Concentration of Carbon in the Austenite Phase at the Sodium-Steel Interface $C_{S}$ and That within the Material $\vec{C}$ for Annealing Times of 1000,4000 , and $10,000 \mathrm{hr}$ for $20 \%$ Cold-worked Type 316 Stainless Steel with an Initial Carbon Concentration of $0.05 \mathrm{wt} \%$. (A carbon concentration of $0.13 \mathrm{ppm}$ in the sodium was used to obtain the variation of $\mathrm{C}_{\mathrm{S}}$ with temperature.) Neg. No. MSD-58575. 
Type 316 stainless steel in the solution-annealed and cold-worked conditions, respectively, for exposure times of 1000,4000 , and $10,000 \mathrm{hr}$. The initial carbon content of the materials is $0.05 \mathrm{wt} \%$. At higher temperatures, the carbon concentrations in austenite closely approximate the equilibrium values, whereas at lower temperatures, the $\bar{C}$ values are substantially higher than the equilibrium carbon concentrations. As the exposure time increases, the deviation of $\bar{C}$ from $C_{\text {eq }}$ decreases at any temperature. For any exposure time, the cold-worked condition results in a smaller deviation of $\bar{C}$ from Ceq, compared with the solution-annealed material at the lower temperatures. Similar plots for solution-annealed Type 304 stainless steel with initial carbon contents of $0.02,0.05$, and 0.08 wt $\%$ are shown in.

Figs. A.6-A.8. A comparison of Figs. A.4 and A.7 illustrates the effect of the lower diffusion coefficient for carbon in Type 304 stainless steel on the carbide-precipitation kinetics.

The carbon concentrations in austenite at the surface of the steel $\left(C_{s}\right)$ for a carbon concentration in sodium of $0.13 \mathrm{ppm}^{*}$ are indicated by the dashed lines in Figs. A.4-A.8. The carbon-concentration difference $C_{s}-\bar{C}$

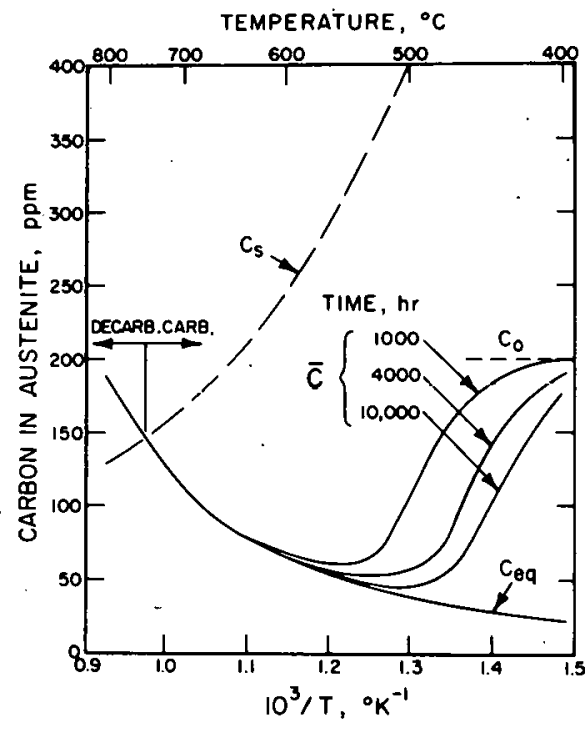

Fig. A.6. Effect of Temperature on Concentration of Carbon in the Austenite Phase at the Sodium-Steel Interface $C_{S}$ and That within the Material $\bar{C}$ for Annealing Times of 1000,4000 , and $10,000 \mathrm{hr}$ for Solution-annealed Type 304 Stainless Steel with an Initial Carbon Concentration of 0.02 wt \%. (A carbon concentration of $0.13 \mathrm{ppm}$ in the sodium was used to obtain the variation of $\mathrm{C}_{\mathrm{S}}$ with temperature.) Neg. No. MSD-58576.

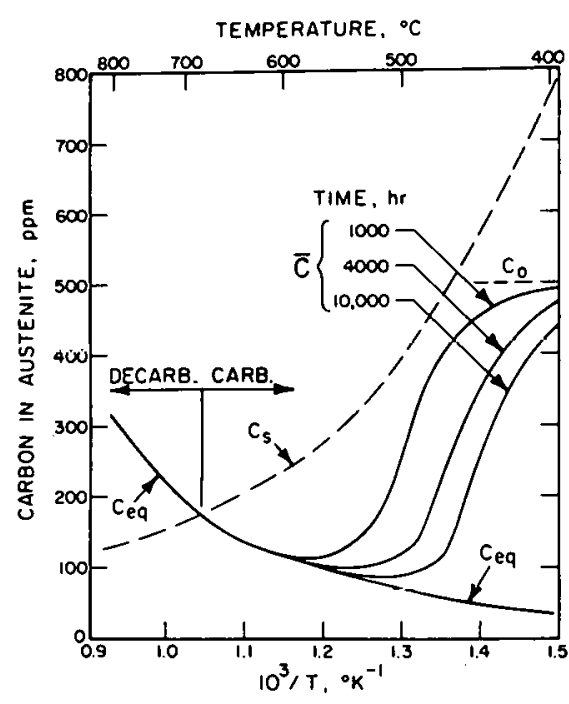

Fig. A.7. Effect of Temperature on Concentration of Carbon in the Austenite Phase at the Sodium-Steel Interface $C_{S}$ and That within the Material $\bar{C}$ for Annealing Times of 1000,4000 , and $10,000 \mathrm{hr}$ for Solution-annealed Type 304 Stainless Steel with an Initial Carboin Concentration of 0.05 wt \%. (A carbon concentration of $0.13 \mathrm{ppm}$ in the sodium was used to obtain the variation of $\mathrm{C}_{\mathrm{S}}$ with temperature.) Neg. No. MSD-58235.

*The carbon concentration in sodium in equilibrium with the steel of a given carbon activity is based upon data for the solubility of carbon in sodium discussed in A ppendix $B$. 


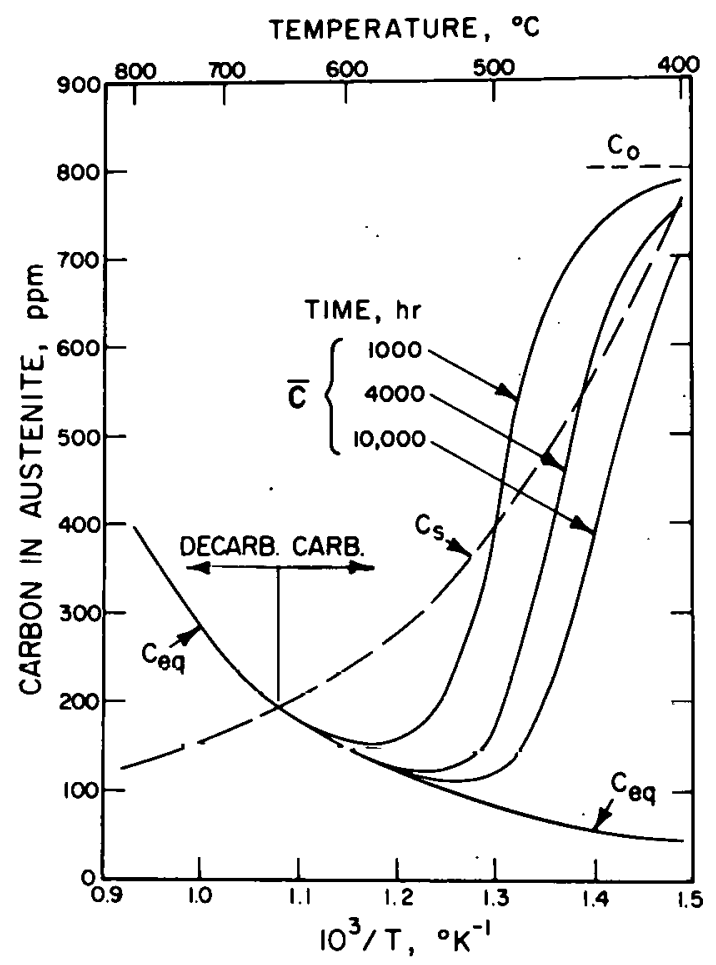

Fig. A.8

Effect of Temperature on Concentration of Carbon in the Austenite Phase at the SodiumSteel Interface $C_{S}$ and That within the Material $\bar{C}$ for Annealing Times of 1000,4000 , and 10,000 hr for Solution-annealed Type 304 Stainless Steel with an Initial Carbon Concentration of 0.08 wt \%. (A carbon concentration of $0.13 \mathrm{ppm}$ in the sodium was used to obtain the variation of $\mathrm{C}_{S}$ with temperature.) Neg. No. MSD-58577.

establishes the driving force for decarburization and carburization at high and low temperatures, respectively, for each exposure time. It is evident that this approach does not influence the driving force at higher temperatures; however, at lower temperatures, $C_{s}-\bar{C}$ is considerably less than $\mathrm{C}_{\mathrm{S}}-\mathrm{C}_{\mathrm{eq}}$. Driving forces for carbon diffusion in the austenite, computed on this basis, were incorporated into the computer program to obtain carbon-concentration-versus-distance profiles in the austenite phase for various exposure times and temperatures. A relationship between the carbon concentration in the austenite phase and the total carbon content in the material (similar to Fig. A.3) under metastable equilibrium conditions was also developed. The solution treatment of a stainless steel at $\sim 1050^{\circ} \mathrm{C}$ results in the dissolution of the carbides, and, upon fast cooling, the initial amount of carbon in the material is retained in the austenite phase. The amount of carbon that precipitates upon thermal aging depends upon the exposure time and temperature, as is evident from Figs. A.4-A.8. The relationship between the carbon concentration in austenite and total carbon content of the material was obtained from Eqs. A.18 and A.19 in a computer subroutine for the temperature and exposure time specified in the main program.

Figure A.9 shows this type of relationship for solution-annealed Type 304 stainless steel after a $4000-\mathrm{hr}$ exposure at temperatures between 400 and $550^{\circ} \mathrm{C}$. The $400^{\circ} \mathrm{C}$ line indicates that almost all the carbon in the steel is retained in the austenite phase because of the slowness of the carbideprecipitation reaction. As the temperature increases, the curves tend toward the values predicted from the $\gamma$-carbide phase equilibrium shown in Fig. A. 3 . 


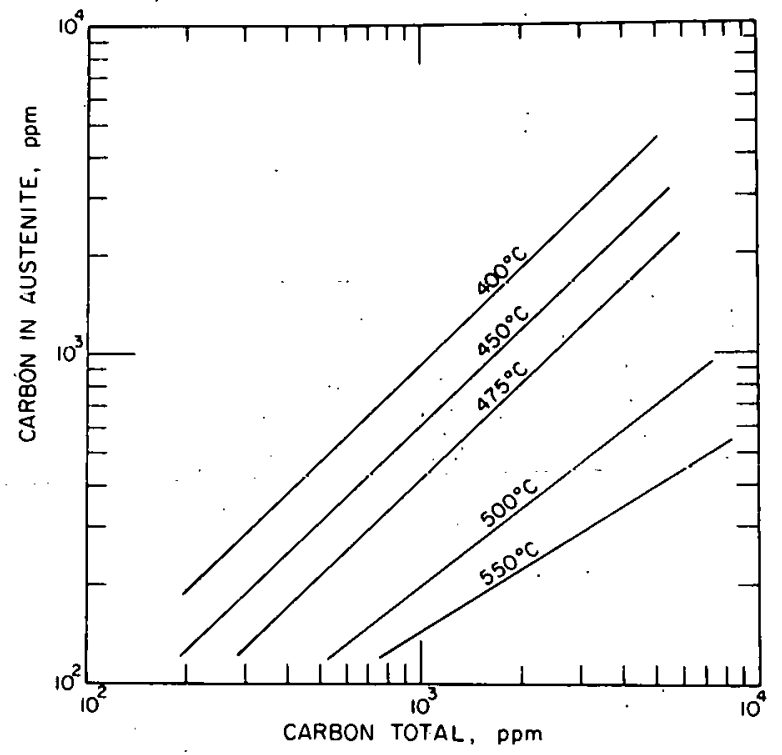

Fig. A:9

Relationship between Carbon Concentration in the Austenite Phase and Total Carbon Content of Solution-annealed Type 304 Stainless Steel after $4000 \mathrm{hr}$ at Temperatures between 400 and $550^{\circ} \mathrm{C}$ under Metastable Austenite-Carbide Equilibrium Conditions. Neg. No. MSD-58578. 


\section{APPENDIX B}

\section{Solubility of Carbon in Sodium}

The solubility of carbon in sodium has been measured by a number of investigator $\mathrm{s}^{55-59}$ using different equilibration techniques and analytical methods. Gratton ${ }^{55}$ reported values between 40 and 80 ppm for the temperature range of $150-700^{\circ} \mathrm{C}$ in sodium containing $40 \mathrm{ppm}$ oxygen. Problems encountered in the separation of particulate carbon with a $5-\mu \mathrm{m}$ stainles $\mathbf{s}$ steel filter from the carbon-saturated sodium could account for the relatively high values and the small variation with temperature. Luner et al. ${ }^{56}$ equilibrated ${ }^{14} \mathrm{C}$-labeled graphite with sodium and concluded that the solubility was less than $0.005 \mathrm{ppm}$ at temperatures below $450^{\circ} \mathrm{C}$.

Longson and Thorley ${ }^{57}$ diffused carbon through a thin-walled nickel capsule containing sodium; the external environment was either a $\mathrm{CO} / \mathrm{CO}_{2}$ gas mixture or sodium containing a carbon source at an activity of unity. Carbon analyses of the sodium in the capsule, along with a knowledge of the carbon activity from the gas composition and the nickel capsule material, were used to obtain solubility values at temperatures in the range of $600-$ $950^{\circ} \mathrm{C}$. Gehri ${ }^{58}$ also used a capsule technique at temperatures between 700 and $1000^{\circ} \mathrm{C}$, in which (1) the sodium was equilibrated in a carbon-saturated nickel crucible, (2) the capsule was inverted to collect the sodium in a copper crucible, and (3) the sodium was analyzed for carbon by a combustion method. Salzano and Newman ${ }^{59}$ obtained carbon solubility values between 575 and $700^{\circ} \mathrm{C}$ by relating the change in the electromotive force of an electrochemical carbon cell to quantitative additions of carbon to sodium

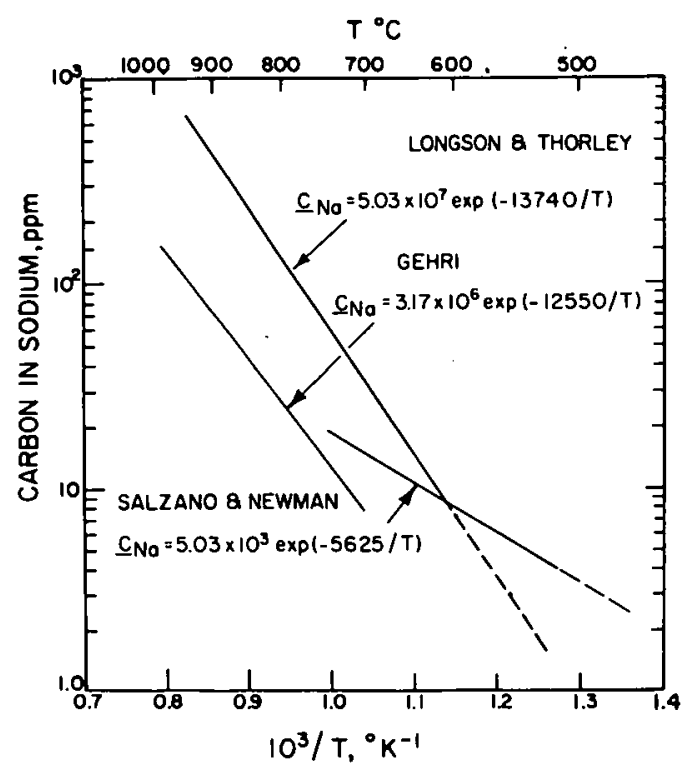

Fig. B.1. Temperature Dependence of Carbon Solubility in Sodium. $57-59$ Neg. No. MSD-55721. contained in a nickel vessel. The carbon-solubility results from the three latter investigations are shown in Fig. B.1. The temperature dependence of the carbon solubility from two of the investigations is in good agreement; however, the actual values differ by a factor of approximately five at any temperature. The data of Salzano and Newman, obtained over a relatively small temperature interval, fall within the results of the other two investigations.

During the development of a foilequilibration method of determining the activity of carbon in liquid sodium, ${ }^{35}$ no correlation could be established between measured carbon activities in the range of interest in reactor sodium systems and carbon analyses of the sodium by the oxyacidic-flux method, ${ }^{60}$ which has a 
sensitivity of $\sim 1 \mu g$ of carbon for a l-g.sample. Since the temperature dependence of the solubility of carbon in sodium is of major importance. in establishing the driving force for carbon migration in athermal loop systems, the carbon-solubility results of either Longson and Thorley or Gehri could be used with measured carbon activities by the foil-equilibration method to obtain carbon concentrations in sodium. In the present report, the carbon concentrations in sodium were obtained by applying Henry's law to the carbon-solubility results of Longson and Thorley; i.e., $\mathrm{C}_{\mathrm{Na}}=$ ${ }^{\mathrm{Na}} \mathrm{C}_{\mathrm{Na}}^{\mathrm{Sat}}$. where

$$
\mathrm{C}_{\mathrm{Na}}^{\mathrm{sat}}(\mathrm{ppm})=5.03 \times 10^{7} \exp (-13,740 / \mathrm{T})
$$

The actual carbon concentration in the sodium is determined by the rate at which carbon is introduced into and removed from the sodium by the loop materials and by other sources or sinks that may be present in the system. For example, operating procedures such as the periodic insertion or removal of test specimens or hardware through a cover gas can dislodge "frost" containing sodium carbonate and other carbon-bearing species into the sodium. This material, upon dissolution, can increase both the oxygen and carbon concentrations of the sodium. Other circumstances and changes in operating conditions can also alter the carbon concentration in the sodium, since no provision exists for carbon control that is analogous to the cold trap, which is used to maintain the oxygen and hydrogen concentrations of the sodium within a narrow range of values. To a large extent, these circumstances account for the wide range of carbon levels that have been observed in reactor materials upon exposure to hightemperaturc flowing sodium.' Since reactor operations (e.g., fuel handling and maintenance) and operating conditions influence the carbon concentration in sodium, it is difficult to predict probable values with the degree of certainty required to relate this information to microstructural changes and the mechanical behavior of materials in the absence of a direct knowledge of the sodium purity (i.e., carbon concentration determined by a foilequilibration method rather than by sodium sampling and analyses). The reported carbon concentration of $1.2 \pm 0.8 \mathrm{ppm}^{61}$ for the sodium in the EBR-II primary system is at the sensitivity limit of the oxyacidic-flux method. Foil equilibrations will be conducted in a specimen-exposure module on the Radioactive Sodium Chemistry Loop (RSCL) at EBR-II to obtain an accurate measure of the carbon activity in sodium. Measurements of this type are routinely performed in out-of-reactor loop systems to correlate microstructural and compositional changes in materials and the mechanical-property behavior with the sodium purity. 
A computer program, based upon the diffusion equations and the mathematical expressions for the thermodynamic and kinetic information described in the present report, was developed to generate carbon concentration-distance profiles in austenitic stainless steels. The simplified flow diagram, shown in Fig. C.l, indicates the operating conditions and the material parameters that must be specified as well as the sequence for performing the computations. The program was written in FORTRAN language for use on the ANL IBM-360 computer. Table C.I is a listing of the program with a description of the various symbols, pertinent comment statements, and an example of the computer output. 

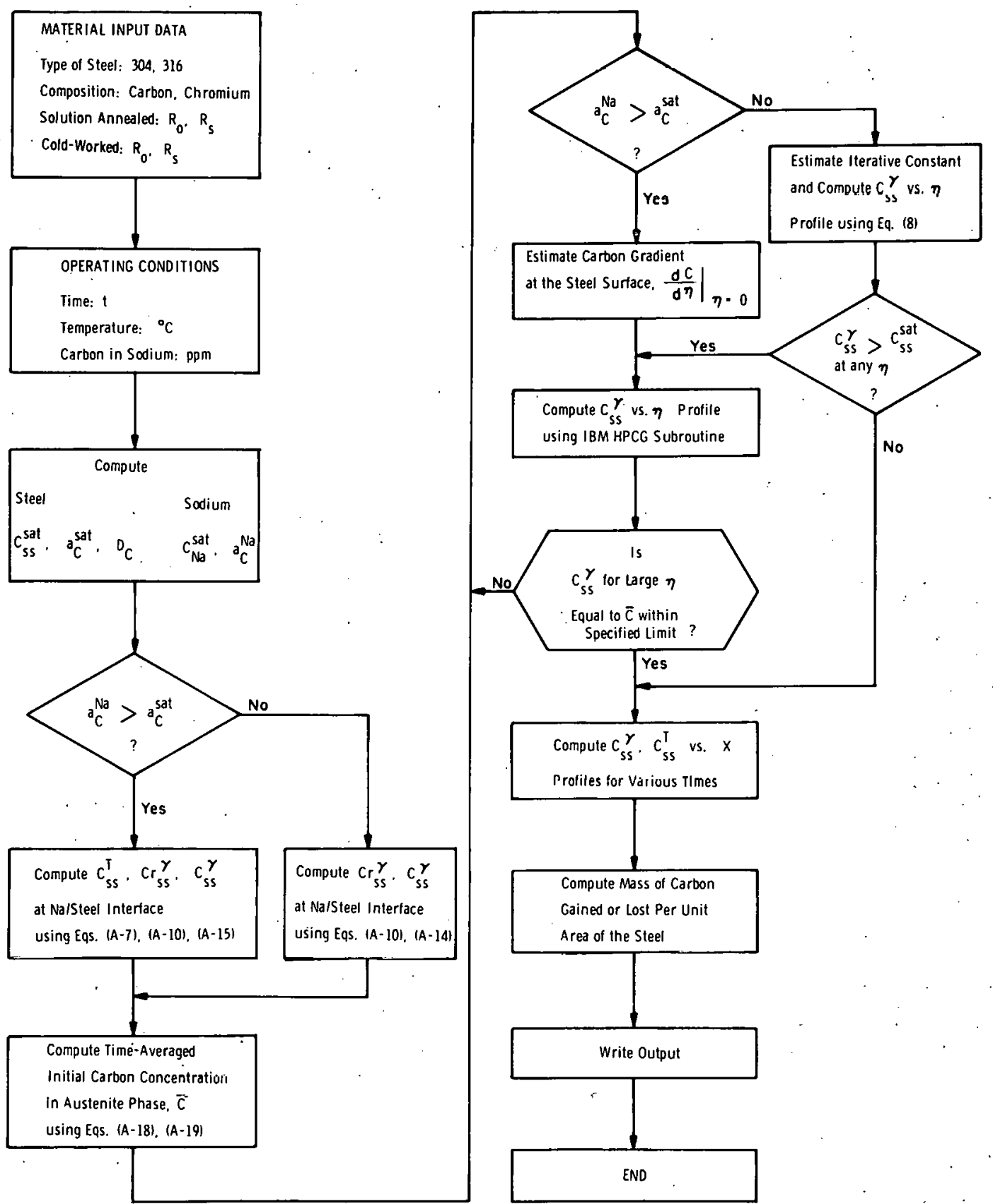

Fig: C.1. Simplified Flow Diagram for Generating Carbon-diffusion Profiles. Neg. No. MSD-58579. 
TABLE C.1. Program Listing and an Example of Computer Output

THIS PROGRAM NUMERICALLY CALCULATES CARBURIZAT ION -DECARBUR IZATION PROFILES IN TYPES 304 AND 316 STAINLESS SIEFL AS A FUNCTION OF TIME, TEMPERA TURE AND CARBON CONCENTRATION IN SODIUM. CTHER VAR IABLES INCLUDE THE INITIAL CARBON AND CHROMIUM CONCENTRALION OF IHE STEELS AND THE CARBIDE PARTICLE.RADI US AND INTERPARTICLE DISTANCE WHICH ARE DEPENDENT UPON THE THERMAL-MECHANICAL CONDI IION OF IHE MATERIAL. THE ANALYSIS IAKES INTO ACCOUNT THE SLOWNESS. OF THE CARB IDE PRECIPITATION PROCESS AT TEMPERATURES BELOW 600 DEGREES CENIIGRADE.

DEFINITLON OC SYMBOLS

ACNA - ACIIVITY OF CARBON IN SODIUM

ACSAT - ACT IVITY OF CARBON AT THE AUSTENITE-CARBIDE PHASE BOUNDARY IN THE STEEL.

ADY - ABSOLUTE VALLE OF YD FINAL,L.E., YO(K)

$A P, A D P$

ATP,BP - TEMPERATURE DEPENDENT CONSTANTS IN EQS. $(A-7)$, BDP $\quad(A-10)$, ANC $(A-15)$

BTP

A0-A8 - COEFFICIENTS IN EQS. $(A-8),(A-9),(A-11)$,

$B O-B 8-(A-12),(A-16)$. ANC $(A-17)$

C1-C6 - COEFFICIENTS ANALOGOUS TO A3 TO A5 AND B3 TO B5 IN EQS. (A-11) AND (A-12) IN MOLE FRACTION UNITS

BADD - VALUE TO READ JUST THE ITERATIVE CONSTANT IN $E Q$. (8)

BOTOM - CENOMINATOR OF EXPRESS ION TO CHANGE THE CARBON ANO CHROMIUM CONCENTRATIONS FRGM PPM AND WI: UNITS. TO MOLE FRAC.TION UNITS

CAVG - TIME AVERAGE CARBON CONCENTRAT ION IN THE AUSIENI IE PHASE FROM EQ. $(A-19)$

CBG - INIT IAL CARBON CONCENTRATION IN THE AUSTENITE PHASE FROM EG. (A-15) FOR ANY GIVEN INIT IAL CARBON CONTENT OF THE STEEL

\begin{tabular}{|c|c|}
\hline $\begin{array}{l}\text { CBM } \\
\text { CB T } \\
\text { CBIGCC }\end{array}$ & $\begin{array}{l}\text { - CBG IN MOLE FRACTION UNITS } \\
\text { - INIIIAL CARBCN CONCENTRATION. IN THE STEEL, PPM } \\
\text { - CBT IN UNITS OF G/CC }\end{array}$ \\
\hline $\begin{array}{l}\text { CBULK } \\
\text { CGBRY }\end{array}$ & $\begin{array}{l}\text { - VALUE OF THE ITERATIVE CONSTANT IN EQ. (8) } \\
\text { - CARBDN CONCENTRATION IN THE AUSTENITE PHASE } \\
\text { THE AUSTENITE / AUSTENUIE + CARBIDE PHASE }\end{array}$ \\
\hline CGSAT & $\begin{aligned} & \text { BOUNDARY, NC IN EQ. (8) } \\
&- \text { SOLUBILITY OF CARBON IN THE FE - } 18 \% \text { CR - 8\%NI } \\
& \text { ALLOY FROM EQ. }(A-13), \text { PPM }\end{aligned}$ \\
\hline CG (I) & $\begin{array}{l}\text { - CARBON CONCENTRATION IN THE AUSTENITE PHASE AT } \\
\text { ANY POS ITION, I, IN THE STEEL FROM THE SOLUTION } \\
\text { TO THE DIFFUSION EGUALION, PPM }\end{array}$ \\
\hline
\end{tabular}


TABLE C.1 (Contd.)

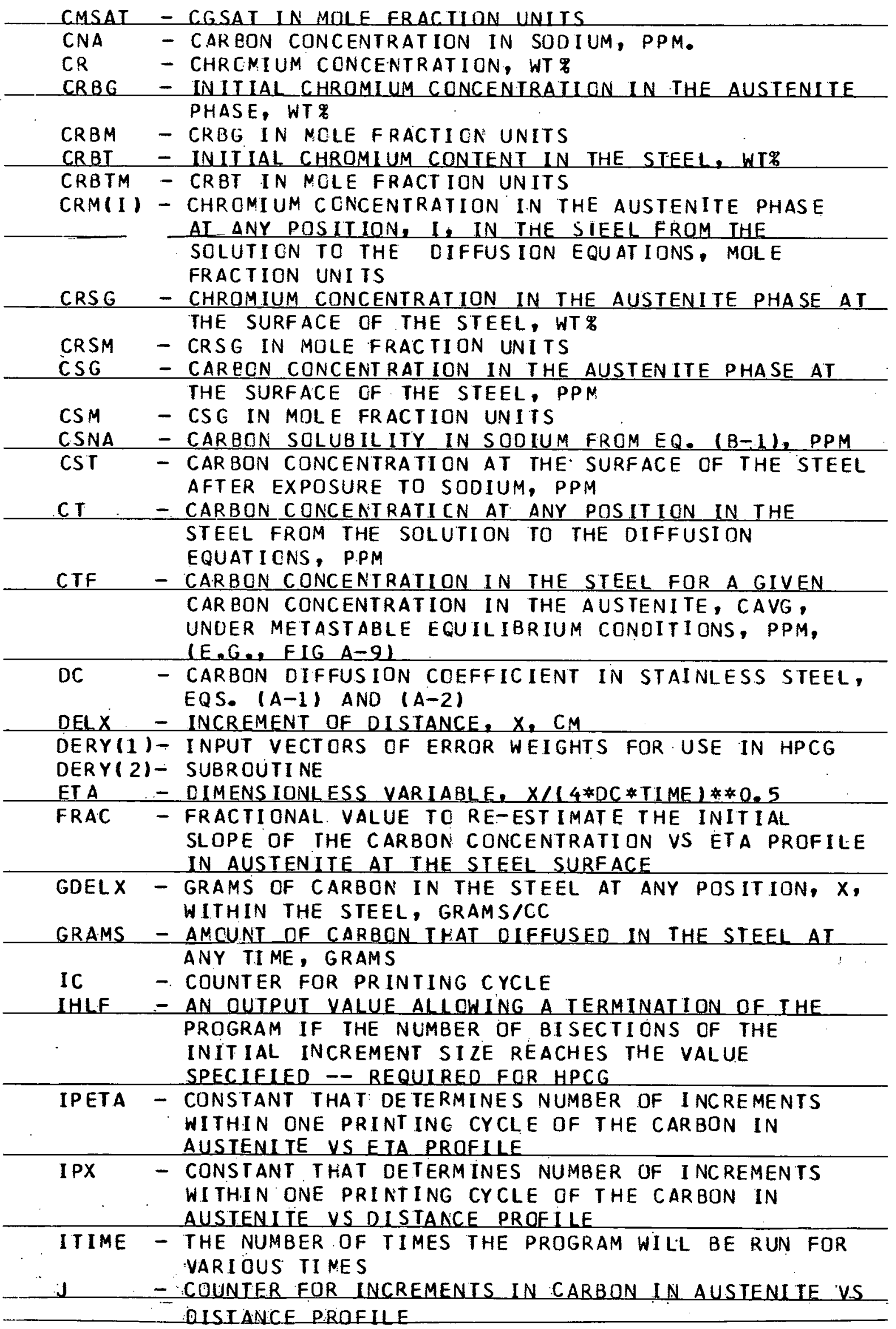


TABLE C.1 (Contd.)

\begin{tabular}{|c|c|}
\hline JJ & $\begin{array}{l}\text { - CCUNTER FOR PRINTING CYCLE IN CARBON IN } \\
\text { AUSTENITE VS DISTANCE PROFILE } \\
\text { - VALUE OF, AT A PRINIUNG CYCLE }\end{array}$ \\
\hline $\begin{array}{ll}\mathrm{J} 2 \\
\mathrm{~K} \\
\end{array}$ & $\begin{array}{l}\text { - VALUE OF J AT THE NEXT PRINT ING CYCLE } \\
\text { - TOTAL NUMBER OF INCREMENTS } \\
\text { - COUNTER FOR INCREMENTS IN CARBON IN AUSTENITE VS }\end{array}$ \\
\hline LSAT & $\begin{array}{l}\text { COUNIER FUR INCREMENIS IN CARBUN IN AUSTENIE VS } \\
\text { - NUMBER OF INCREMENIS INTO WHICH THE SINGLE- } \\
\text { PHASE REGION OF THE SIFEI IS DIVIDED }\end{array}$ \\
\hline $\begin{array}{l}\text { LSTART } \\
M\end{array}$ & $\begin{array}{l}\text { - INITIAL INCREMENT VALUE FOR THE TWO-PHASE } \\
\text { REGION OF THE STEEL } \\
\text { - COUNTER FOR NUMBER OF AOJUSTMENIS TO INITIAL }\end{array}$ \\
\hline $\begin{array}{l}\text { MSS } \\
\text { NDLM }\end{array}$ & $\begin{aligned} & \text { SLOPE OR I TERATIVE CONSTANT } \\
& \text { - TYPE OF STEEL, } 304 \text { OR } 316 \\
& \text { - NUMBER OF EQUAT IONS IHAT ARE USED IN HPCG }\end{aligned}$ \\
\hline $\begin{array}{l}\text { PPM } \\
\text { PRMI }\end{array}$ & $\begin{aligned} & \text { SUBROUTINF } \\
& \text { - PARIS PER NILLION EY WEIGHT } \\
& \text { - INIUIAL VALUF OF EIA - BFQULRED BY HPCG }\end{aligned}$ \\
\hline $\begin{array}{l}\text { PRMT ( } 2) \\
\text { PRMT ( 3) } \\
\text { PRMT ( } 4 \text { ) }\end{array}$ & $\begin{array}{l}\text { - FINAL VALUE OF ETA -- REQU IRED BY HPCG } \\
\text { - INCREMENT SI ZE OF ETA - REQUIRED EY HPCG } \\
\text { - UPPER ERBOR BOUND - REQUIRED BY HPCG }\end{array}$ \\
\hline $\begin{array}{l}\text { PRMT (5) } \\
\text { R }\end{array}$ & $\begin{array}{l}\text { - CONSTANT INITIALIZEO AT ZERO -- REQUIRED FOR } \\
\text { HPCG } \\
\text { - GAS CONSIANT, } 1.987 \text { CAL/G-MOLE-DEGREE K }\end{array}$ \\
\hline $\begin{array}{l}\text { RO } \\
\text { RS }\end{array}$ & $\begin{array}{l}\text { - RADIUS OF THE CARBIDE PARTICLE, CM } \\
\text { - THE RADIUS OF THE EQUIVALENT SPHERE SURROUNDING } \\
\text { A. CARBIDE PARIICLE, CM }\end{array}$ \\
\hline $\begin{array}{l}\text { S } \\
\text { SLOPE } \\
I\end{array}$ & $\begin{array}{l}\text { - TEMPERATURE DEPENOENT CONSTANT } \\
\text { - VALUES OF Y(1) STORED IN THE COMPUTER } \\
\text { - IEMPERATURE, CEGREES K }\end{array}$ \\
\hline $\begin{array}{l}\text { TC } \\
\text { THRS } \\
\text { LIME }\end{array}$ & $\begin{array}{l}\text { - TEMPERA TURE, DEGREES C } \\
\text { - TIME, HRS } \\
\text { - IIME, SEC }\end{array}$ \\
\hline $\begin{array}{l}\text { TLAST } \\
\text { TRCEP T }\end{array}$ & $\begin{array}{l}\text { - TIME - REQUIRED FOR SUBROUTINES CTCG AND CGCT, } \\
\text { SEC } \\
\text { - IEMPFRATURE DEFENDENT CONSTANT. ANALOGOUS TO BP }\end{array}$ \\
\hline TYEAR & $\begin{array}{l}\text { IN EQS. }(A-13) \text { AND }(A-12) \text {, IN MOLE FRACTION } \\
\text { UNITS } \\
\text { IUME, YEARS }\end{array}$ \\
\hline $\begin{array}{l}X \\
\text { YADD }\end{array}$ & $\begin{array}{l}\text { - PENETRATION DISTANCE, CM } \\
\text { - VALUE USED IN RE-ESTIMATIOG THE CARBON } \\
\text { CONCENTRAIUN GRADIENT AI THE SURFACE OF THE }\end{array}$ \\
\hline YFIN & $\begin{array}{l}\text { STEEL } \\
\text { - CARBON CONCENTRATION IN THE AUSTENITE PHASE FOR } \\
\text { THE I AST INCREMENT IN THE STEFL AT LARGE } X_{*} \text { IN } \\
\end{array}$ \\
\hline $\mathbf{Y} \mathbf{1}$ & $\begin{array}{l}\text { MOLE FRACIION UNITS } \\
\text { - INITIAL VALUE FOR THE CARBON CONCENTRATION } \\
\text { GRADIENI IN IHE AUSTFNIIE PHASE IN THE TWO- }\end{array}$ \\
\hline $\begin{array}{l}Y(1) \\
Y(1.2)\end{array}$ & $\begin{array}{l}\text { PHASE AUSTENITE + CARBIDE REGION } \\
\text { - YI - REQUIRED BY THE PHCG SUBROUTINE } \\
\text { - CARBON CONCENTRALICN IN THE AUSTENITE PHASE AI }\end{array}$ \\
\hline & $\begin{array}{l}\text { THE SURFACE OF THE STEEL FOR USE IN HPCG } \\
\text { SUBROUTINE, MOLE FRACT ION UNITS } \\
\text { - MAXIMUM VALUE OF IHE CARBON CONCENTRATION } \\
\end{array}$ \\
\hline & GRAD IENT IN THE AUSTENITE PHASE IN THE IASI \\
\hline
\end{tabular}


TABLE C.1 (Contd.)

THIS IS T.HE MAIN PROGRAM

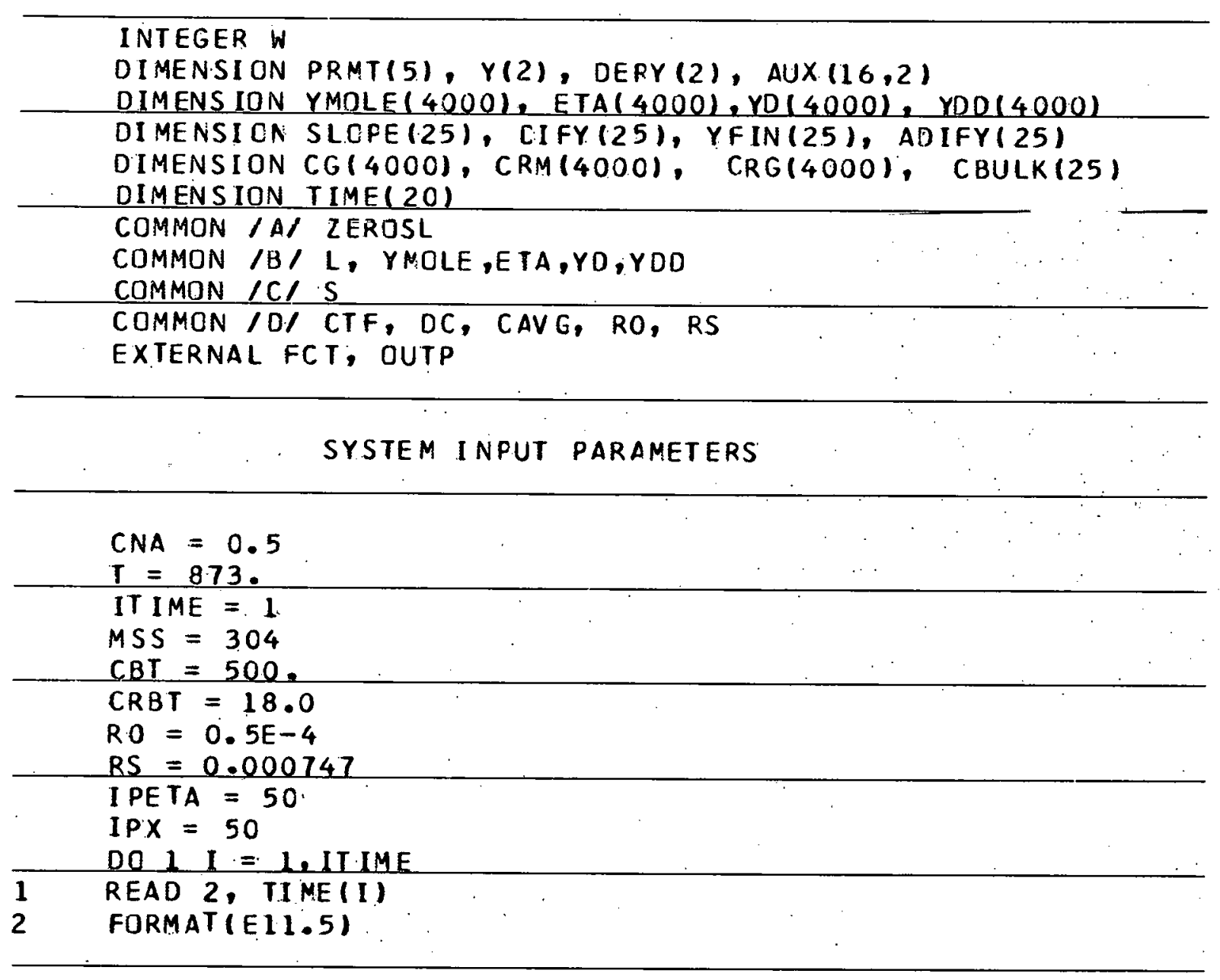

\section{REQUIRED CONSTANTS}

$\begin{aligned} R & =1.987 \\ A 0 & =14.15 \\ A 1 & =-1.74 E+03 \\ A 2 & =-9.84 E-4 \\ A 3 & =31.86 \\ A 4 & =-1.42 E+04 \\ A 5 & =-2.186 E-2 \\ A 6 & =1.752 \\ A 7 & =-468.0 \\ A 8 & =-7.12 E-04 \\ B 0 & =2.0 \\ B 1 & =-4.52 E+02 \\ B 2 & =-5.87 E-4 \\ B 3 & =-343.5\end{aligned}$


TABLE C.1 (Contd.)

$B 4=1.47 E+05$
$B 5=0.232$
$B 6=-7.673$
$B 7=1553.0$
$B 8=7.93 E-3$
$C 1=0.339881$
$C 2=-1.51352 E+02$
$C 3=-2.32864 E-04$
$C 4=0.539688$
$C 5=-3.03159 E+02$
$C 6=-4.05861 E-04$
$P P M=1.0 E+6$
ZEROSL $=1.0 E-5$

CALCULATION OF IHE ACIIVITY AND SOLUBULIIY OF CARBON IN SODIUM ANC THE SOLUBIL ITY OF CARBON IN THE STEEL

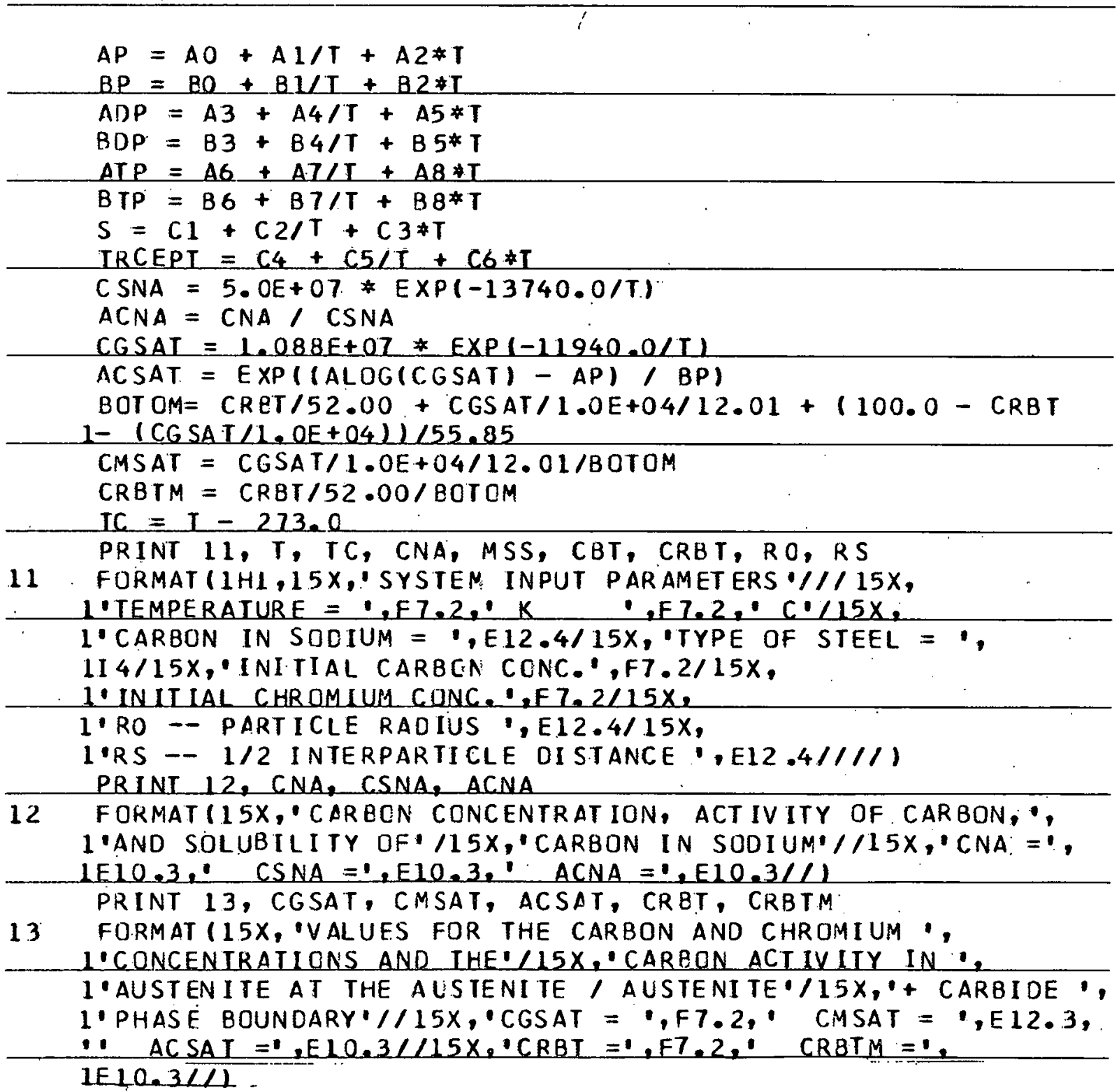


TABLE C.1 (Contd.)

CALCULAIION OF THE OLFFUSICN COEFFICIENT OF CARBON IN THE STEEL

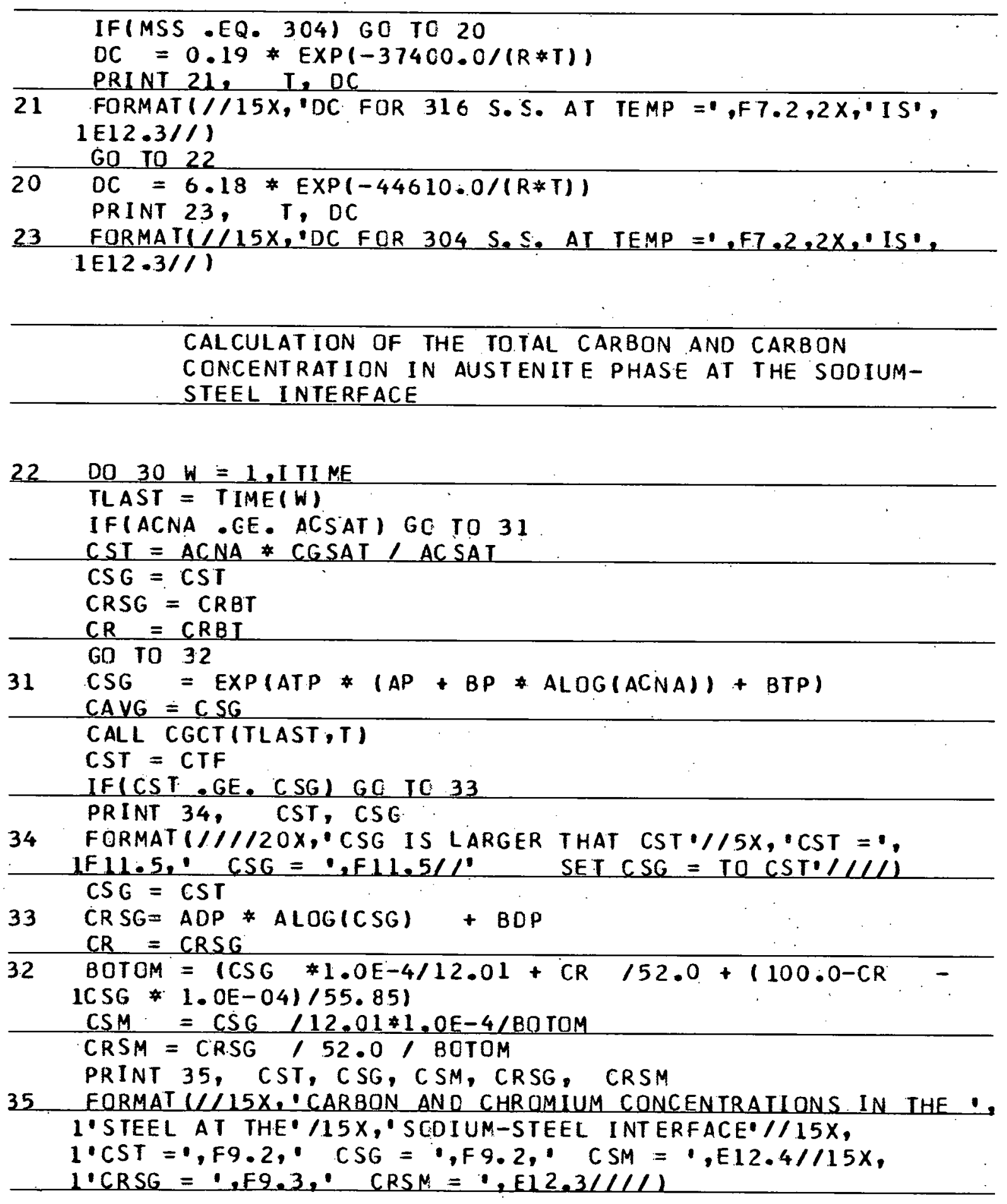


TABLE C.1 (Contd.)

CALCULATION OF CARBON CONCENTRATION IN THE AUSTENITE PHASE FOR A SPECIFIEO INIIIAL CARBON CONTENT IN THE STEEL

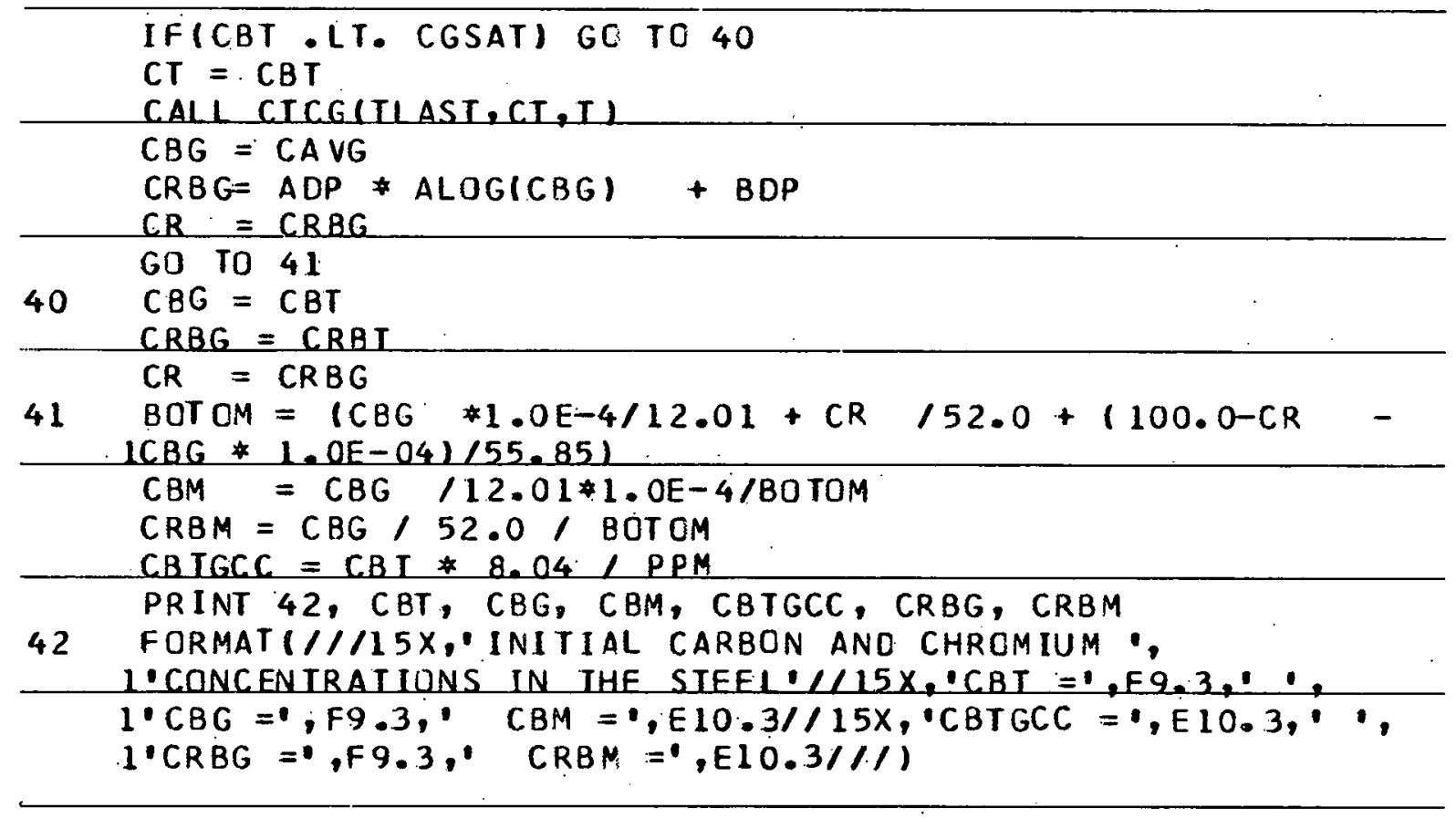

THIS SECTION DE TERMINES THE CARBON CONCENTRATION VS EIA PROFILE

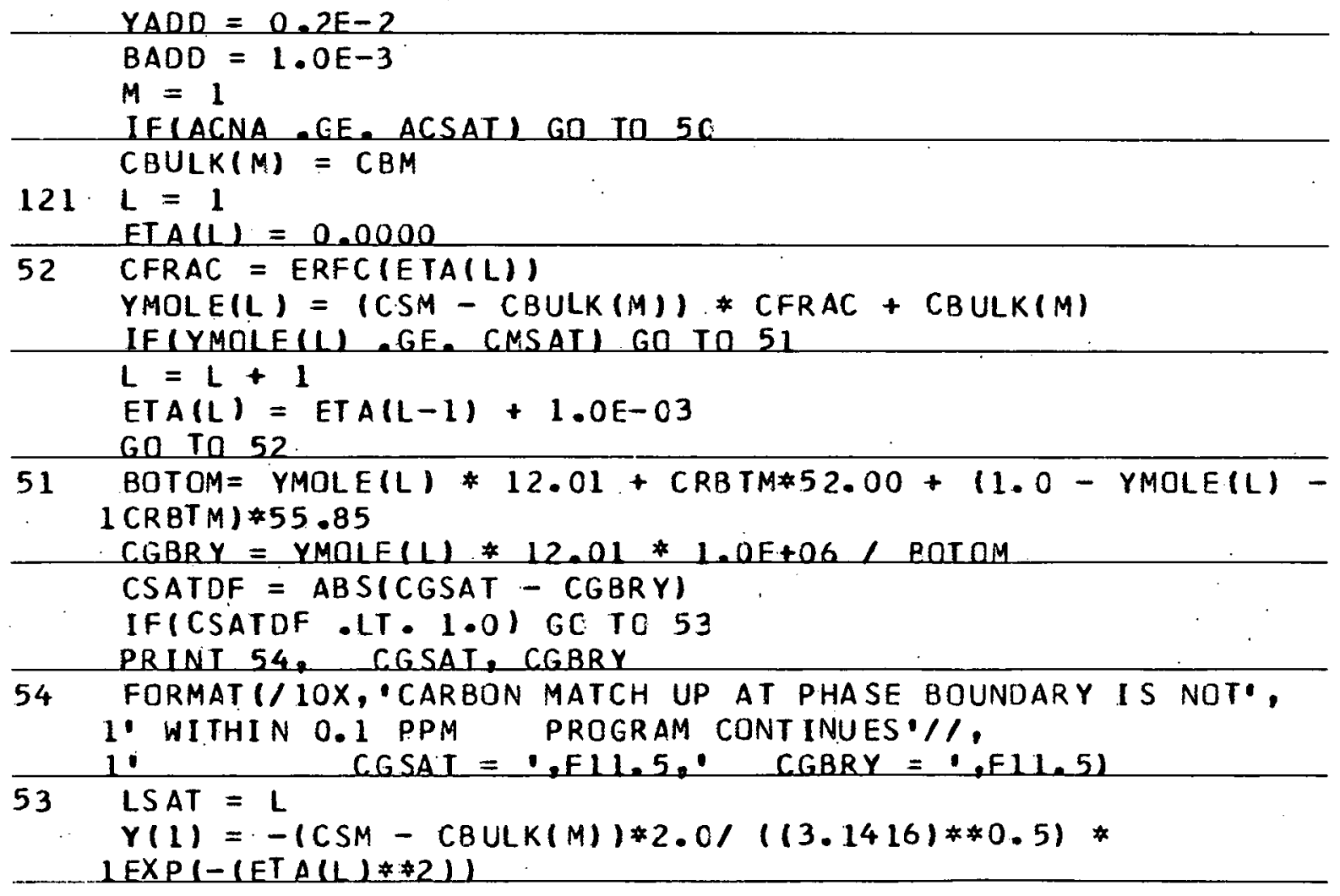


TABLE C. 1 (Contd.)

$\operatorname{SLOPE}(M)=Y(1)$

$Y 1=Y(1)$

$Y(2)=Y M O L E(L)$

PRMTUU) = ETA(H)

PRMT $(2)=E T A(L)+.4 .0$

$L=L+1$

GO TO 55

ESTIMATE INITIAL CARBON GRACIENT IN THE TWO-PHASE RECION

50 IFICST.GT. 20000.) GO TO 56

$Y(1)=-5.20 E-9 *(C . S T-C B I)$

GO TO 57

$56 \quad Y(1)=-5.20 E-11 *(C S T-C B T)$

$57 \quad Y 1=Y(1)$

132 SLOPE $(M)=Y 1$

$Y(2)=C S M$

$Y(1)=Y 1$

$\mathbf{L}=\mathbf{I}$

PRMT (1) $=0.0$

PRMT(2) $=4.0$

55 PRMT (3) $=1$. OE-3

PRMT (4) $=2.0 E-6$

$\operatorname{PRMT}(5)=0.0$

DERY (1) $=0.5$

$\operatorname{DERY}(2)=0.5$

$\mathrm{NDIM}=2$

IHLF $=1$

CALL HPCG (PRMT, Y, DERY, NDIM, IHLF, FCT, OUTP, AUX)

THIS SECTION CHECKS FINAL, VALUE FOR CARBON CONCENTRATION IN AUSTENITE PHASE OBIAINED

NUMER ICALLY WITH CBM. IF NOT WITHIN SPECIFIED

LI MIT THEN PROGRAM GOES TO SECT ION WHICH DETERMINES NEW INIILAL CARBON GRADIENT, OTHERWIZE GO TO

SECTION WHICH PRINTS OUT RESULTS

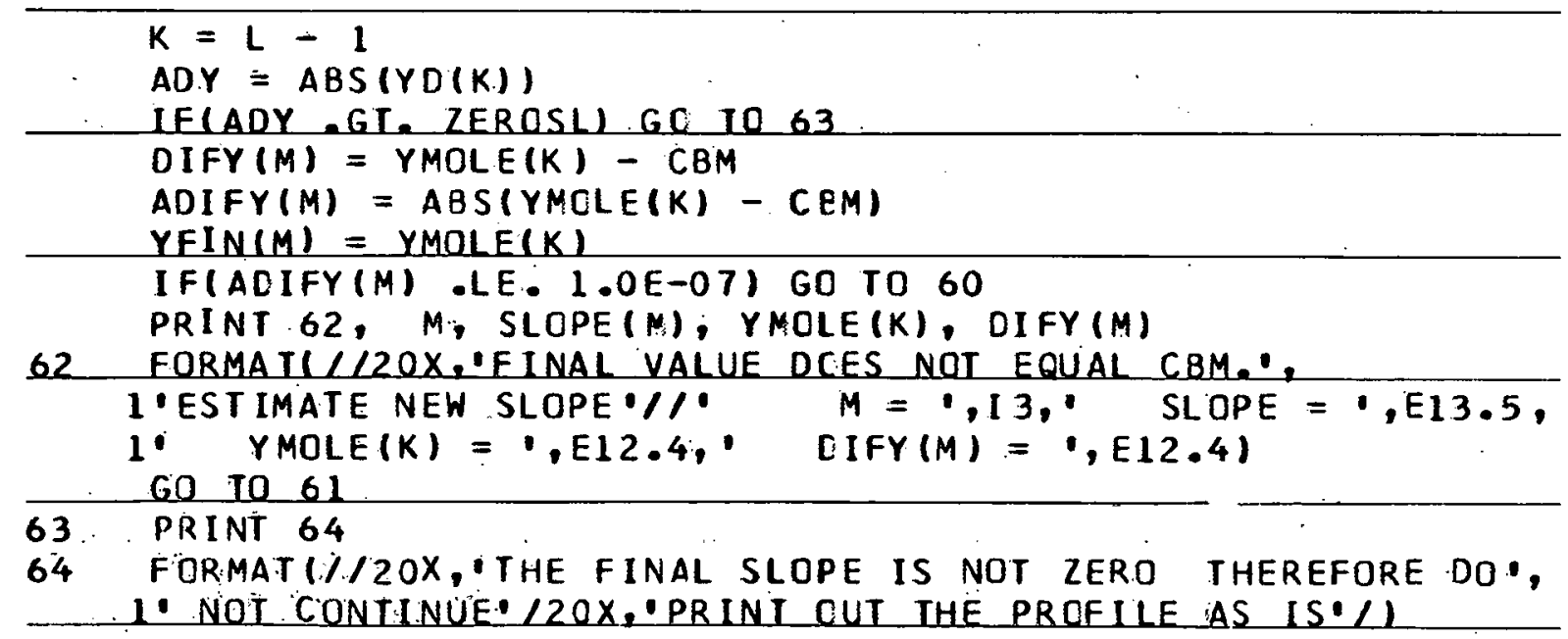


TABLE C.l (Contd.)

THIS SECTICN PRINTS OUT CARBON CONCENTRATION VS ETA PROFILE

6.0 PRINT $71, M, \operatorname{SLOPF}(M), Y M N L E(K), D I F Y(M)$

71 FORMAT $/ / 20 \mathrm{X}$, 'THIS IS THE DESIRED SLOPE, DC/DX, THAT',

1. GIVES CBM! $/ 1, \quad M=1,13, \circ$ SLOPE $=1$, E13.5,

1. $\quad Y M O L E(K)=1, E 12.4, \quad$ DLFY $(M)=1, E 12.4 / / / / / / / 4 X$,

1. THIS IS THE CARBON IN AUSTENITE VS ETA PROFILE $* 1$ '

$\mathrm{JJ}=$ IPETA - 1

IFLACNA.GE. ACSAI) GO IO 72

PRINT 73

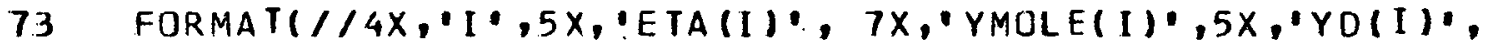

$16 X,{ }^{\circ} C G(L), 4 X,{ }^{\circ}$ CRGLI) $/ / 1$

DO $74 \quad I=1$, LSAT

BOTOM $=$ YMOLE(I) $* 12.01+$ CRBTM*52.00+(1.0-YMOLE(I)

$1-(R B I M) \neq 55.85$

CG(I) $=1.0 E+06 *$ YNCLE (I) *12.01/ BOTCM

$C R G(I)=C R B T$

$Y D(I)=-(C S M-C B U L K(M)) * 2.0 /(3.1416) * 0.5) *$

$\operatorname{IEXP}(-(E T A(I) * 2))$

$J J=J J+1$

IF (JJ.EQ. LPETA) GO TO 75

GO TO 74

$75 \mathrm{JJ}=\mathrm{JJ}-$ IPETA

PRINT 72, L, EIAUU, YMOLFUL, YOUL, CGUH, CRGUH

77 FORMAT $(3 X, I 4,2 X, E 10.3,2 X, E 10.3,2 X, E 10.3,2 X, F 7.2,2 X, F 7.2)$

74 CONTINUE

$I=$ LSAT

PRINT 78, I, ETAII), YMOLE(I), YD(I), CG(I), CRG(I)

78 FORMAT ( / 4X,' VALUES AT THE AUSTENITE / AUSTENITE + ',

1.CARB IDE PHASE BOUNDARY $13 x, 14,2 X, E 10,3,2 X, E 10,3,2 X$.

$1 E 10.3,2 X, F 7.2,2 X, F 7.2 / 11$

LSTART $=$ LSAT +1

GO TO 79

72 LSTART $=1$

79 PRINT 80

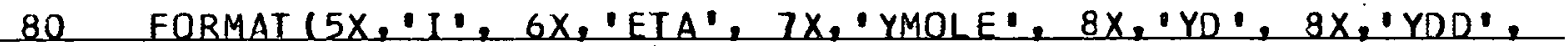

$17 \times, ' C G ', 4 X, ' C R G ')$

DO $81 \quad 1=$ LSTART,K

CRMII) $=S$ * ALOG $(Y M O L E(I))+$ TRCEPT

BOTOM $=$ YMOLE (I)*12.01+CRN(I)*52.00+(1.0-YMOLE(I)-

$1 C R M(I)) * 55.85$

$C G(U)=1.0 E+6$ YMOLFIU*12.01/ BOTOM

$C R G(I)=A D P * A L O G(C G(I))+B D P$

$\mathrm{JJ}=\mathrm{J} \mathrm{J}+1$

IF(J).EQ. LPEIA) GC IO 82

GO TO 81

$82 \mathrm{JJ}=\mathrm{JJ}-\mathrm{IPETA}$

PRINT 83, I, ETAUL, YMOLEU, YOUI, YDDCU, CG(I),

ICRG(I)

83 FORMAT $(3 X, 14,4(1 X, E 10.3), 1 X, F 7.2,1 X, F 5.2)$

81 CONTUNUE 
TABLE் C.1 (Contd.)

THE TOTAL CARBON PROFILE IS DETERMINED FROM THE CARBON.IN AUSTENITE PROFILE. ALSO IHE MASS OF CARBON GAINED OR LOST PER SQUARE CENTIMETER OF THE STEEL IS CALCULATED.

$K 1=K-1$

$\operatorname{THRS}=\operatorname{TIME}(W) / 3600.0$

TYEAR = THRS / 24.00/365.0

PRINT 90, TINE(W), THRS, TYEAR

90 FURMATU/3X,14HTIME IN SEC. $=, E 11.5 / 3 \times, 14 H T$ IME IN HRS. $=$,

IF11.5/3X, 'TIME IN YEARS $=\bullet, F 10.5 / 13 X$, 'THIS I S THE ',

1.CARBON IN AUSTENITE ANO TOTAL CARBON /3X,

1 'VS $X$ PROFILE AND THE MASS OF CARBON GAINED OR LOST'/3X,

l'Per SQuare (ENT IMETER OF THE STEEL')

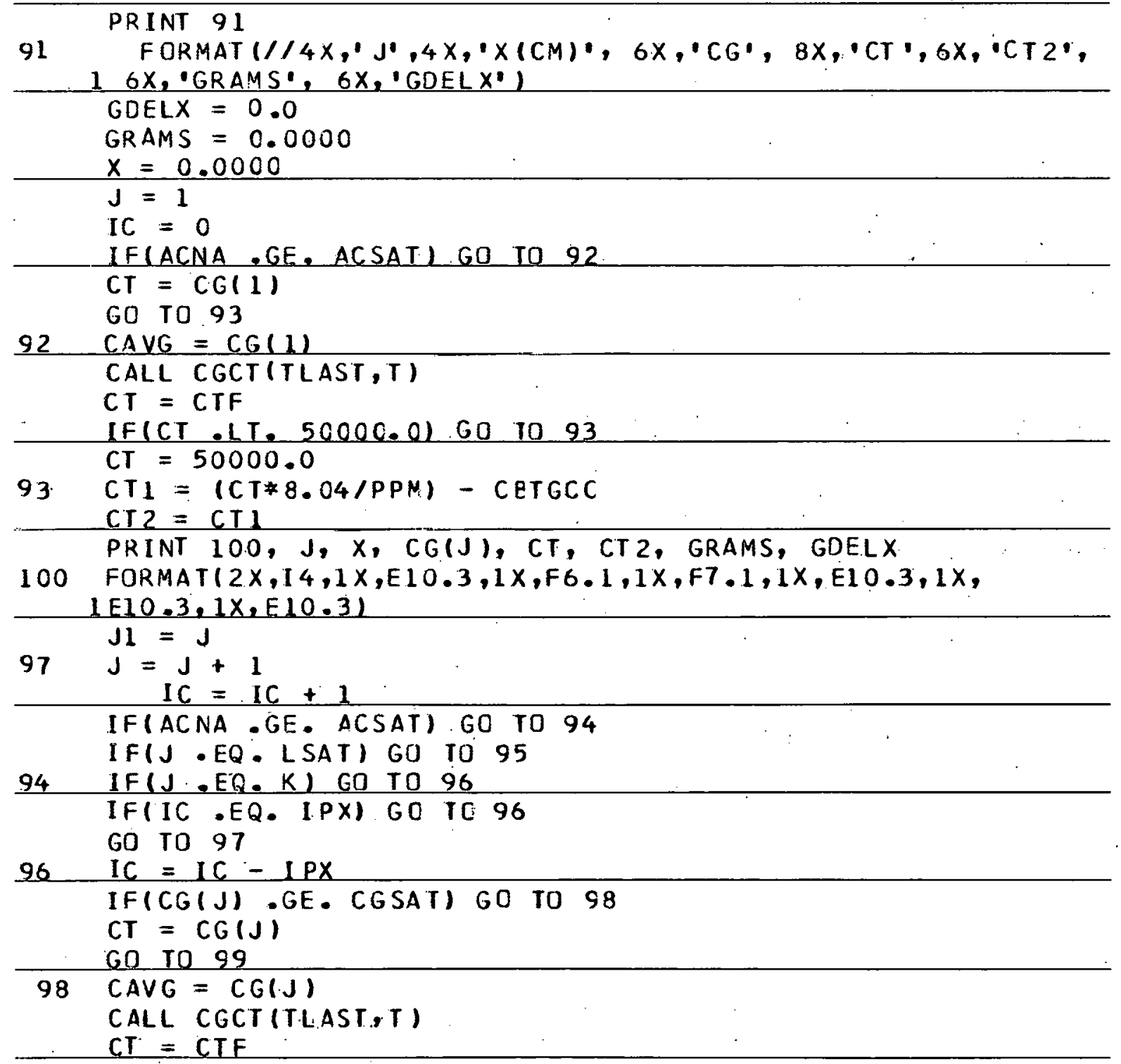


TA.BLE C.1 (Contd.)

IELCI LI. 50000.01 GO TO 99

$C T=50000.0$

$99 \quad C_{2}=(C T * 8.04 / P P M)-C B T G C C$

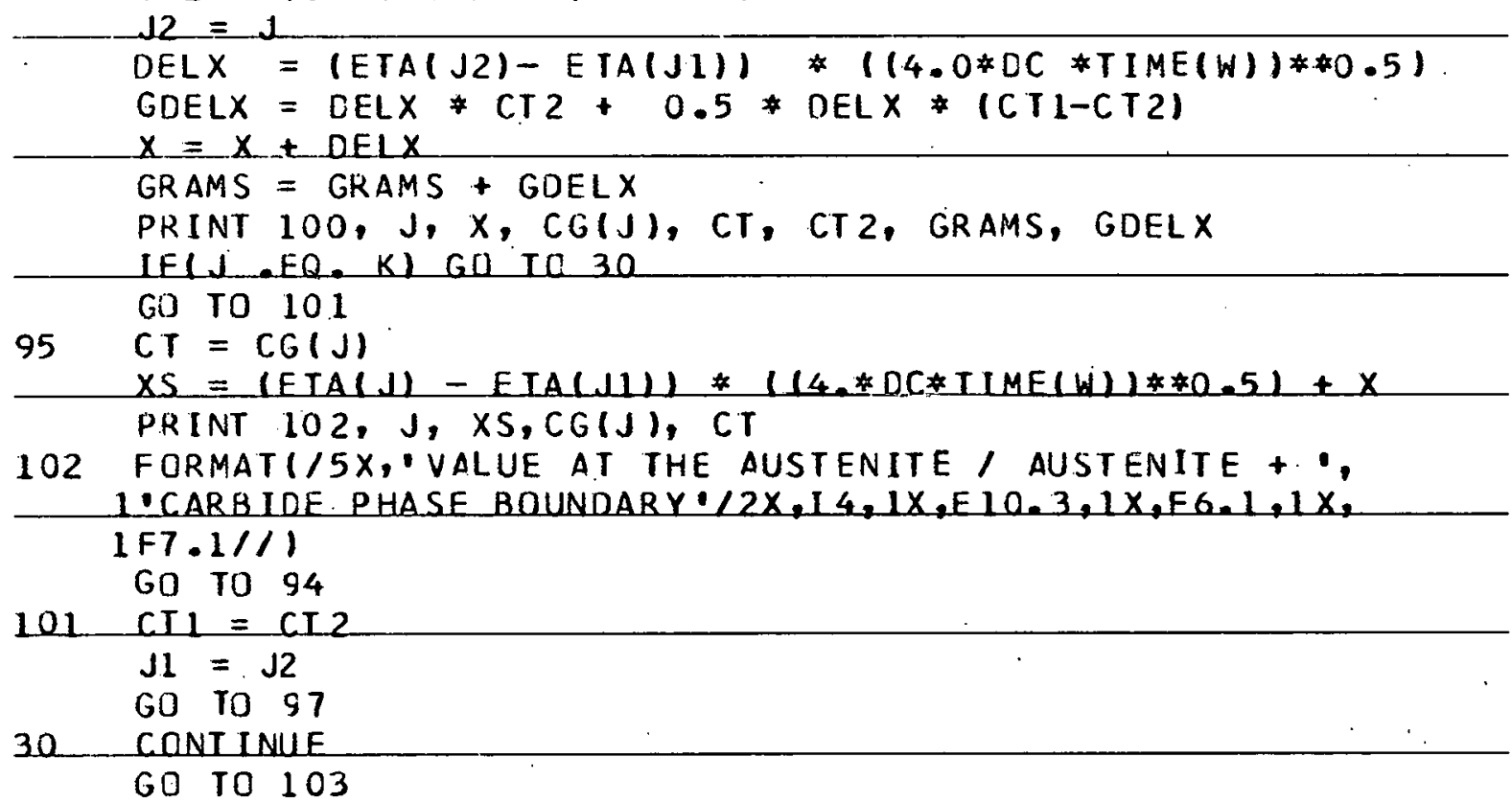

THIS SECT ION REESTIMATES THE CARBON CONCENTRATION GRADIENT

61 IF (ACNA . GE. ACSAT) GO TO 110

IF $(M-1)$ 111, 111, 112

111 IF (YMOLE(K) - CBM) $113,60,114$

$113 \operatorname{CBULK}(M+1)=\operatorname{CBULK}(N)+B A D C$ $G O \quad I O \quad 115$

$114 \operatorname{CBULK}(M+1)=\operatorname{CBULK}(M)-B A D C$ GO TO 115

112 IFICIFY $(M)$ a L 0.0$)$ GO In 116

IF(DIFY $(N-1) \cdot G T \cdot 0.0)$ GO TE 114

GO TO 117

116 IF(DIFY $(M-1)$ at .0 .0$)$ GO IO 113

$F R A C=(C B M-Y F I N(M)) /(Y F I N(M-1)-Y F I N(M))$

$\operatorname{CBULK}(M+1)=\operatorname{CBULK}(M)+F R A C *(\operatorname{CBULK}(M-1)-\operatorname{CBULK}(M))$ GO TO 118

1.7 FRAC $=(Y F I N(M)-C B M),(Y F I N(M)-Y F I N(M-1))$

CBULK $(M+1)=\operatorname{CBULK}(M)-F R A C *(C B U L K(M)-\operatorname{CBULK}(M-1))$

118 BADD $=B A O D / 10.0$

115 IF (M . GT . 20) GO TO 119

$M=M+1$

GO TO 121

110 IF(M - 1$) 122,122,123$

122 IF(YMOLE (K) - CBM) $124,60,125$

$124 \quad Y 1=Y 1+Y A D D$

GO TO 126

$125 \quad Y_{1}=Y_{1}-Y_{A D D}$

$60 \mathrm{In} 126$ 
TABLE C.1 (Contd.)

\begin{tabular}{|c|c|}
\hline 127 & $\begin{array}{l}\text { GO TO. } 128 \\
\text { IF(OIFY(M-1) } \\
\text { GO IO } 129\end{array}$ \\
\hline 128 & $\begin{array}{lllll}\text { IF (DIFY }(M-1) & \text {.GT. } 0.01 & \text { GO TO } 125 \\
\text { GO TO } 130 & & & \end{array}$ \\
\hline 129 & 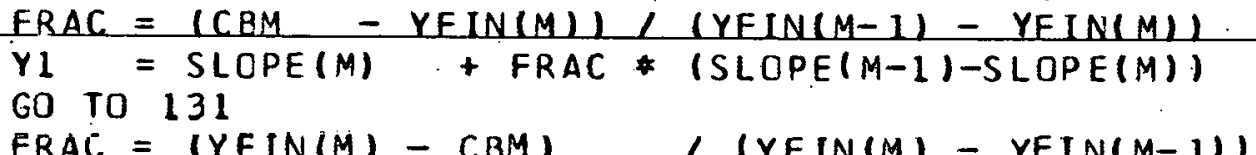 \\
\hline 130 & 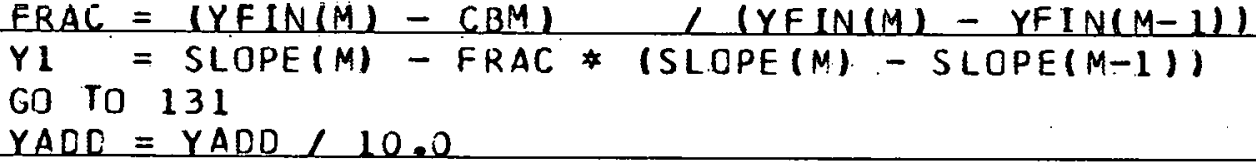 \\
\hline 126 & $\begin{array}{l}I F(M \cdot G T, 20) \quad G 0 \text { TO } 119 \\
M=M+1 \\
G 0 T 0132\end{array}$ \\
\hline $\begin{array}{l}119 \\
133\end{array}$ & $\begin{array}{l}\text { PRINT } 133 \\
\text { FORMAT } 1 / / 2 X, \cdot M \text { IS LARGER THAN } 20 \cdot / / \text { ) } \\
\text { GO TO } 60\end{array}$ \\
\hline 103 & $\begin{array}{l}\text { CONTINUE } \\
\text { STOP } \\
\text { END }\end{array}$ \\
\hline
\end{tabular}

THIS SUBRCUTINE NUMERICALLY DETERMINES THE CARBON IN AUSTENITE V.S ETA PROFILE

SUBRDUT INE HPCG (PRMT, Y, DERY, NDI M, IHLF, FCT, OUT P, AUX)

DIMENS ION PRMT (1),Y(1), DERY(1), AUX 16,1$)$

DIMENSION YMOLE $(4000)$, ETA(4000), YO(4000), YDD(4000)

COMMON /A/ ZEROSL

COMMON /B/ L, YMOLE,ETA, YD, YDD

COMMON $/ C / \mathrm{S}$

$N=1$

IHLF $=0$

$X=P R M T(1)$

$H=$ PRMT ( 3 )

$\operatorname{PRMT}(5)=0$.

DO $11=1$, NDIM

$\operatorname{AUX}(16, I)=0$.

$A \cup X(15, I)=D E R \cdot Y(I)$

$1 \quad A U X(1, I)=Y(I)$

IF ( H* (PRNT $(2)-X)) 3,2,4$

ERR OR RETURNS

2 I HLF $=12$

GOTO 4

3 IHLF $=13$

COMPUTATION OF DERY FOR: STARTING VALUES

4 CALL FCT $(X, Y$, DERY $)$ 
TABLE C.1 (Contd.)

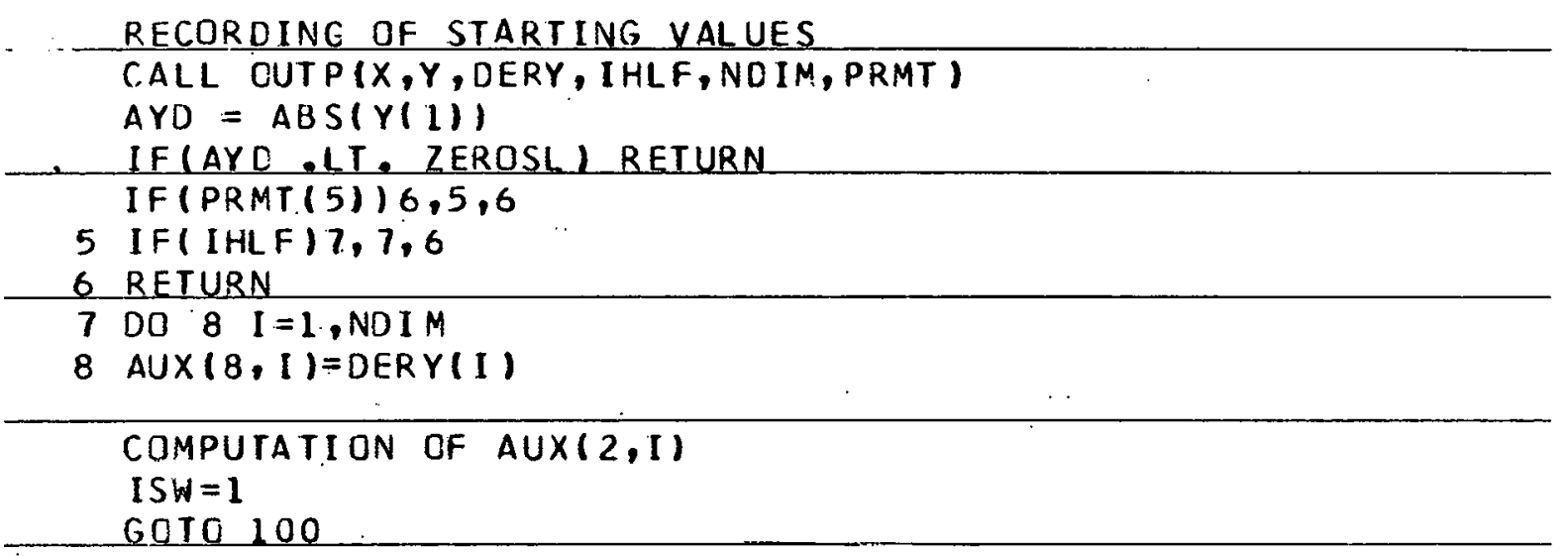
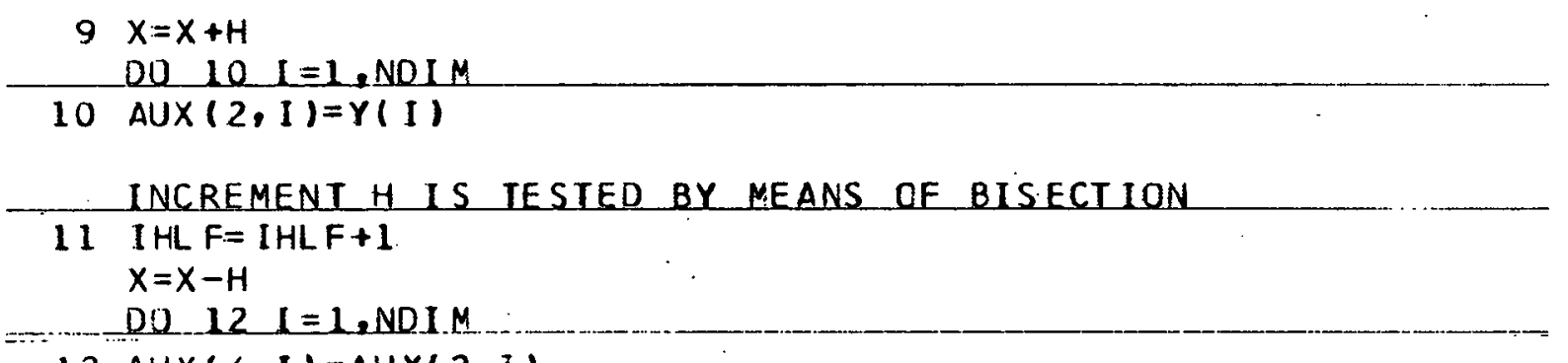

12. $\operatorname{AUX}(4, I)=\operatorname{AU} \times(2,1)$

$H=.5 * H$

$\mathrm{N}=\mathbf{l}$

$I S W=2$

GOTO 100

$13 x=X+H$

CALL FCT $(X, Y, D E R Y)$

$\mathrm{N}=2$

DO $14 \quad[=1$. NOIN

$A \cup X(2, I)=Y(I)$

$14 \operatorname{AUX}(9, I)=\operatorname{DERY}(\mathrm{I})$

$\mathrm{ISW}=3$

GOTO 100

COMPUTATION OF 'IEST VALUE DELT

15 DEL $T=0$.
$D O \quad 16 \quad I=1$, NDIM
16 DF $T=D E I T+A U X I$

16 DEL $T=D E L T+A U X(15, U) * A B S(Y(U)-A U X(4, U)$

$D E L T=.06666667 * D E L T$

IF (DELT-PRMT(4))19,19,17

17 IF (IHLF-10)11, 18,18

NO SATISFACTORY ACCURACY AFTER 10 BISECTIONS. ERROR MESSAGE

18 I HLF $=11$

$X=X+H$

GOTO 4 
TABLE C.1 (Contd.)

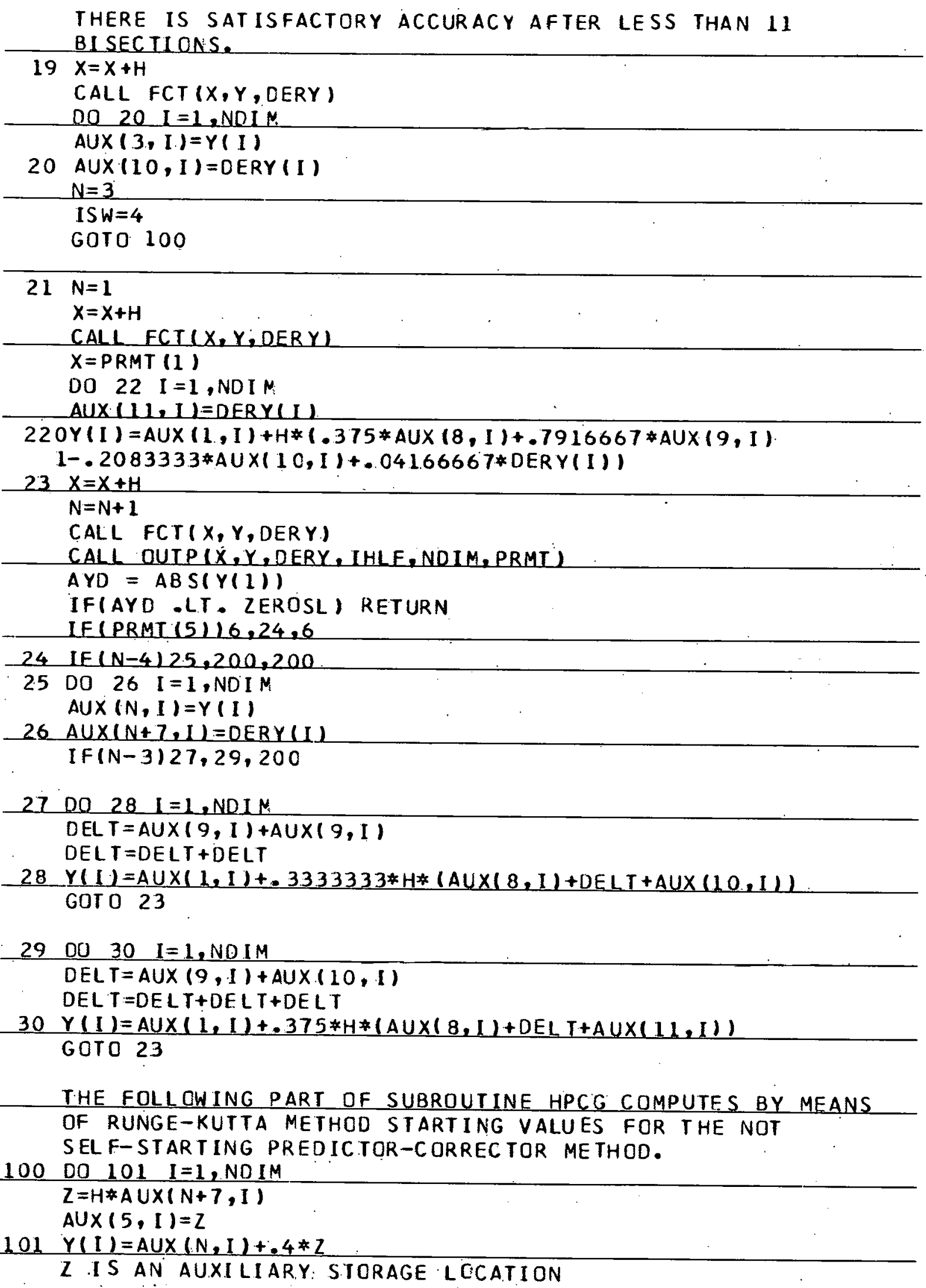


TABLE C.1 (Contd.)

$Z=X+.4 * H$

CALL FCTIZ,Y,DERY)

DO $102 \mathrm{I}=1$, NDIM

$Z=H * D E R Y U U$

$\operatorname{AUX}(6, I)=Z$

$102 Y(I)=\operatorname{AUX}(N, I)+.2969776 * \operatorname{AUX}(5, I)+.1587596 * Z$

$Z=X+.4557372 * H$

CALL FCT $(Z, Y$, OERY $)$

DO $103 \quad I=1$, NDIM

$Z=H * D E R Y(I)$

$A \cup X(7, I)=2$

$103 Y(I)=A U \times(N, I)+.2181004 * A \cup \times(5, I)-3.050965 * A U \times(6, I)+$

$13.832865 * 2$

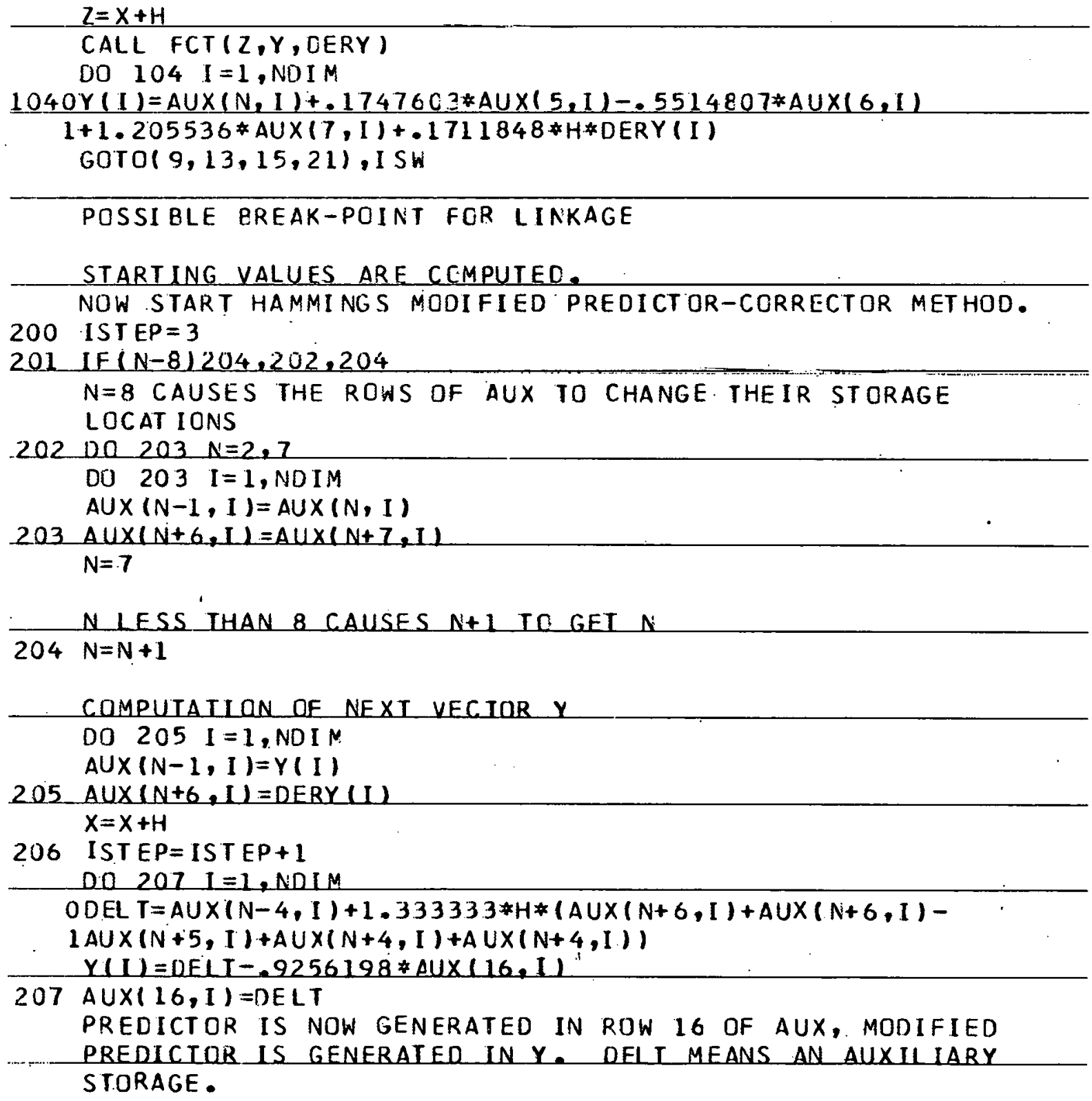


TABLE C. 1 (Contd.)

CALL FCIXX,Y,DERYL

DER IVAT IVE OF MODIFIED. PREDICTOR IS GENERATED IN DERY

$-\cdots-00 \quad 208 \quad 1=1, N D I N$

ODEL $T=.125 *(9 . * A U X(N-1, I)-A U X(N-3, I)+3 . * H *(D E R Y(I)+$

$1 A U X(N+6, I)+A U X(N+6, I)-A U X(N+5, I))$

AUX $(16,1)=A U \times(16,1)-0 E L I$

$208 Y(1)=D E L T+.07438017 * A U \times(16, I)$

TESL WHETHER H MUST BE HALVED OR DOUBLED

DEL $T=0$.

DO $209 I=1$, NDI $M$

209 DELT $=D E L I+A U \times(15,1)$ ABS $(A \cup \times(16,1)$

IF (DEL T-PRMT (4)) $210,2.22,222$

H MUST NOT BE HALVED. THAI NEANS Y (I.) ARE GOOO.

210 CALL FCT $(X, Y, D E R Y)$

CALL OUTP $(X, Y, D E R Y$, IHLF, NDIM, PRMT $)$

$A Y D=A B S(Y(1))$.

IFIAYD . LT . ZEROSL) RETURN

IF ( PRMT ( 5$)) 212,211,212$

211 IFI IHLF $-111213,212,212$

212. RETURN

213 IF $\left(H^{*}(X-P R M T(2))\right) 214,212,212$

214 IFL LABS $(X-P B M I(2))-.1 * A B S(H)) 212,215,215$

215 IF (DELT-.02*PRMT (4)) $216,216,201$

H COUL B BE DOUBLED. IF ALL NECESSARY PRECEEDING VALUES ARE AVAILABLE

21.6 IF(IHLF):201,201,217

217 IF $(\mathrm{N}-7) 201,218,218$

218 IF (ISTEP-4) 201,219,219

219 IMOD $=$ IST EP/ 2

IFUSTEP-IMCD-IMODI201,220.201

$220 \mathrm{H}=\mathrm{H}+\mathrm{H}$

I $H L F=I H L F-1$

I STEP $=0$

DO $221 I=1, N D I M$

$\operatorname{AUX}(\mathrm{N}-1,1)=\operatorname{AUX}(\mathrm{N}-2, \mathrm{I})$

$A \cup X(N-2, I)=A \cup X(N-4, \cdot 1)$

$\operatorname{AUX}(\mathrm{N}-3, I)=\operatorname{AUX}(\mathrm{N}-6, \mathrm{I})$

$A \cup X(N+6, I)=A \cup X(N+5, I)$

$A \cup X(N+5, I)=A \cup X(N+3, I)$

$A U X(N+4, I)=A U X(N+1, I)$

$D E L T=A U X(N+6, I)+A U X(N+5, I)$

$D E L T=D E L T+D E L T+D E L T$

2210 AUX $(16, I)=8.962963 *(Y(I)-A U X(N-3, I))-3.361111 * H *(D E R Y(I)+$ IDEL T+AUX $(N+4, I))$

GOTO 201 
TABLE C. 1 (Contd.)
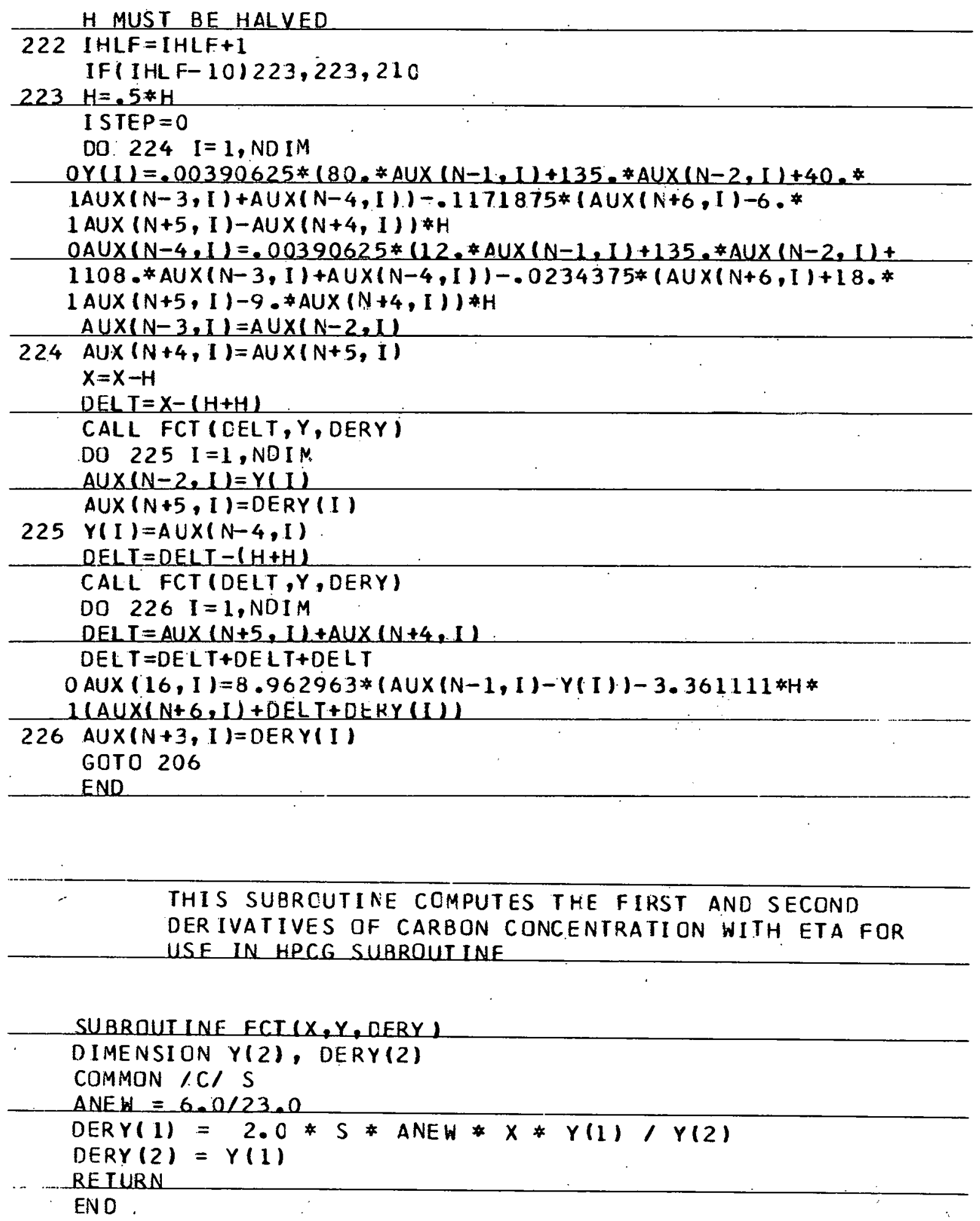
TABLE C.1 (Contd.)

THIS SUBRCUTINE STORES VALUES OF ETA, CARBON : CONCENTRATION AT VARIOUS ETAS AND FIRST AND SECOND DERIVAIUVES OF CARBON CONCENT RAT ION FOR FUTURE USF

SUBROUTINE CUTP(X,Y,OERY, IHLF, NDIM,PRMI)

DIMENSION $Y(2)$, : DERY(2), PRMT(5)

DIMENSION YMOLE (4000), ETA(4000), YD(4000), YDD(4000)

COMMON $\angle B / L, Y M O L E, E T A, Y D, Y D D$

$Y M O L E(L)=Y(2)$

$E T A(L)=X$

$Y D(L)=Y(1)$

$Y D D(L)=\operatorname{CERY}(1)$

$L=L+L$

RETURN

END.

THIS SUBROUTINE. CALCULATES CARBON CONCENTRATION

IN AUSTENITE PHASE FOR A GIVEN INITIAL CARBON CONIENT OF THE STEEL

SURROUI INE CTCGITLAST,CT, I)

COMMON /D/ CTF, DC, CAVE, RO, RS

DIMENSION CRATIO(30), SUMT(30), CAV(2000)

$P I=3.14159$

$A O=1.752$

$A 1=-468.0$

$A 2=-7 \cdot 12 E-4$

$\mathrm{BO}=-7.673$

$B 1=1553.0$

$B 2=7.93 E-3$

SIGMA $=0.00$

BETA $=$ RO/RS

$V O L=B F T A * 3$

$R S=R O / B E T A$

$\mathrm{N}=100$

IFITLAST.GI. 3.16E+07) $N=200$

IF (TLAST .GT $\quad 1.58 E+C .8) \quad N=400$

$A=A O+A 1 / T+A 2 * T$

$B=B O+B 1 / T+B 2 * T$

$\operatorname{CAV}(1)=C T$

$C E Q=E X P(A * A L O G(C A V(1))+B)$

$N 2=N *$ ?

DTIME $=$ TLAST $/ \mathrm{N}$

DO $1 \mathrm{~J}=1, \mathrm{~N} 2$

IFRAC $=$ RTIME $* 1 / 2$

SUM $=0.0$

DO $2 \quad M=1,10$

$X 0=(M-1) \div P U / 11.0-B E I A)$ 
TABLE C.I (Contd.)

\begin{tabular}{|c|c|}
\hline 5 & $\begin{array}{l}X 1=M * P I /(1.0-B E T A) \\
X=(X 0+X 1) / 2.0 \\
E X=A T A N(X *(1.0-S I G M A * B E I A))(X .0+S I G M A * B E T A * X * X))-11.0\end{array}$ \\
\hline & $\begin{array}{l}1-B E T A) * X+(M-1) * P I \\
F X 1=A T A N((X 1 *(1.0-S I G M A * B E T A)) /(1.0+S I G M A * B E T A * \times 1 * \times 1))- \\
1(1.0-B E T A) * X 1+(M-1) \neq P 1\end{array}$ \\
\hline & 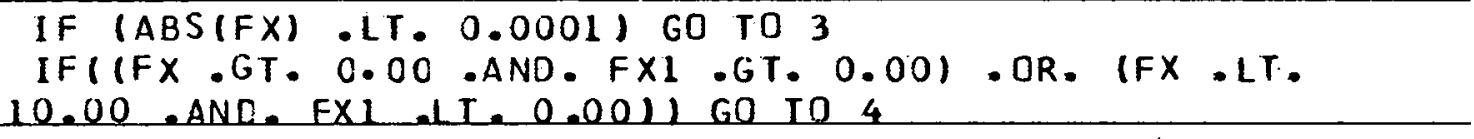 \\
\hline 4 & $\begin{array}{l}x 0=x \\
G 0 \text { TO } 5 \\
X 1=x\end{array}$ \\
\hline 3 & $\begin{array}{l}\text { GO TO } 5 \\
\text { ALPHA }=x \\
\text { DELTA }=x-\text { ATAN }(X)\end{array}$ \\
\hline & $\begin{array}{l}C N=1.0 /((12.0 * P I * R O) *((1,0-8 E T A) *(A L P H A * 2)- \\
\text { IBETA) } /(B E T A *(1.0+A L P H A * 2)))+(S I G M A /(1.0+(S I G M A * \\
\text { IBETA*X)*(2.0)) })(*(0.5))\end{array}$ \\
\hline & 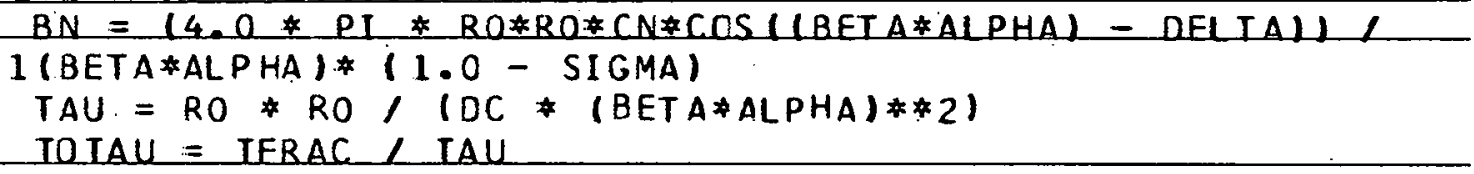 \\
\hline & $\begin{array}{l}\text { CRATIO(M) }=(3.0)((4.0 * P I * R S * 3) *(1-B E T A * 3))) * \\
1(B N * 2) *(1.0-\operatorname{EXP}(-T O T A U)) \\
\text { SUM }=\text { CRATIO }(M)+\operatorname{SUM}\end{array}$ \\
\hline 2 & $\begin{array}{l}\text { SUMT }(M)=\text { SUM } \\
\text { CONTINUE } \\
\text { CAY }(J+I)=C I+(C E Q-C I) * \operatorname{SUMT}(10)\end{array}$ \\
\hline 1 & $\begin{array}{l}\text { CONT INUE } \\
K=1 \\
\text { TAREA }=0.0\end{array}$ \\
\hline 10 & $\begin{array}{l}A C T=\text { DTIME } / 6.0 * \text { (CAV }(K)+4.0 * C A V(K+1)+C A V(K+2)) \\
\text { IAREA = TAREA+ACT } \\
\text { IF }(K+2) . E Q .(N 2+1)) \text { GO TO } 6\end{array}$ \\
\hline 8 & $\begin{array}{l}\text { IF }((K+2), L E \cdot(N 2+1)) \text { GO TO } 7 \\
\text { PRINT } 8 \\
\text { FORMAT }(/ 5 X, \text { WWARNING IN SUBROUTINE CTCG }\end{array}$ \\
\hline 7 & $\begin{array}{l}1 \cdot \text { THAN } N+1 \cdot / 1 \\
\text { GO TO } 9 \\
\text { CONT INUE }\end{array}$ \\
\hline 9 & $\begin{array}{l}K=K+2 \\
\text { GO TO } 10 \\
\text { CONTINUE }\end{array}$ \\
\hline 6 & $\begin{array}{l}\text { CAVG = TAREA / TLAST } \\
\text { RETURN } \\
\text { END }\end{array}$ \\
\hline
\end{tabular}


TABLE C.1 (Contd.)

THIS SUBROUTINE CALCULATES THE TOTAL CARBON CONTENT FOR A GIVEN CARBON IN AUSTENITE

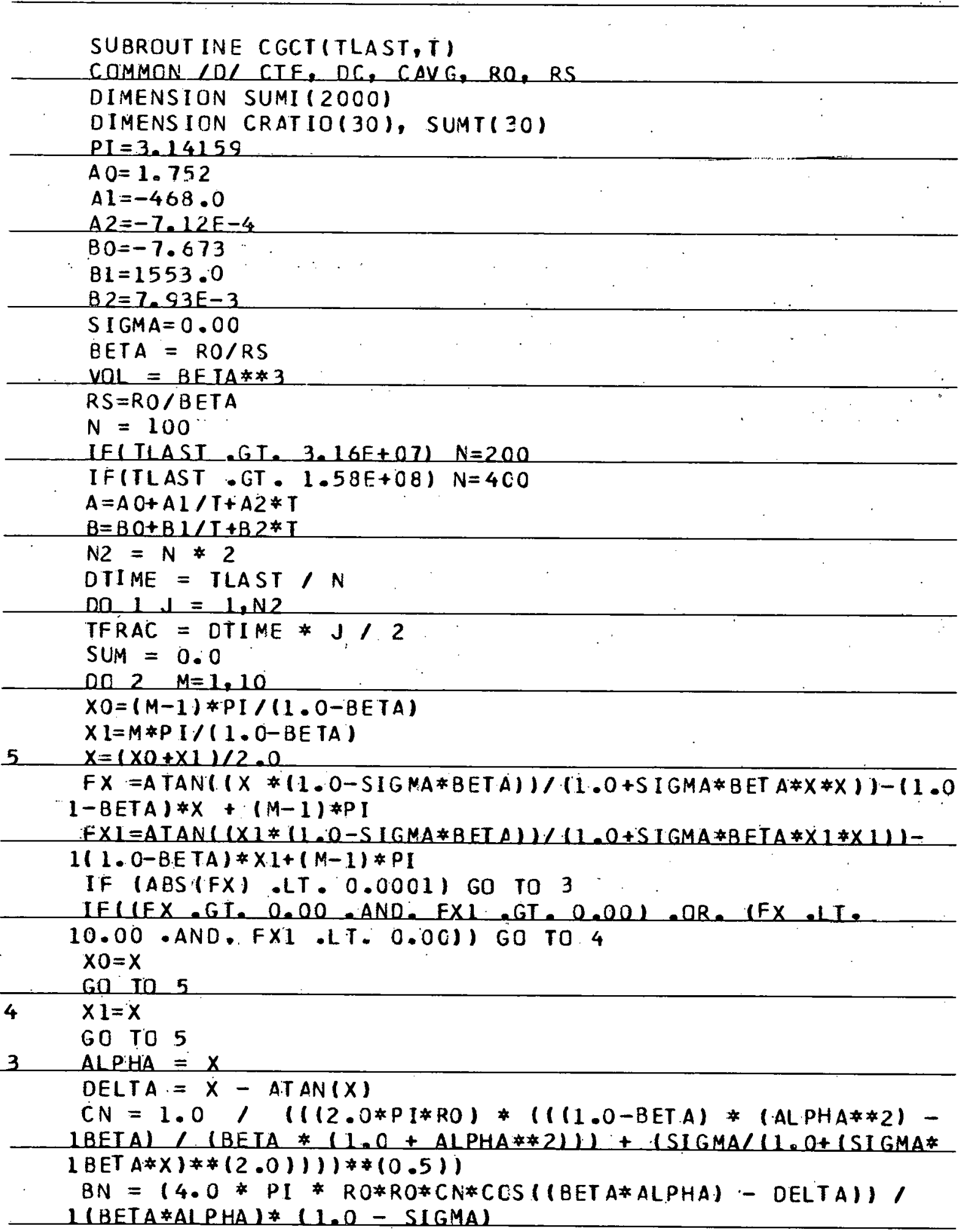


TABLE C.1 (Contd.)

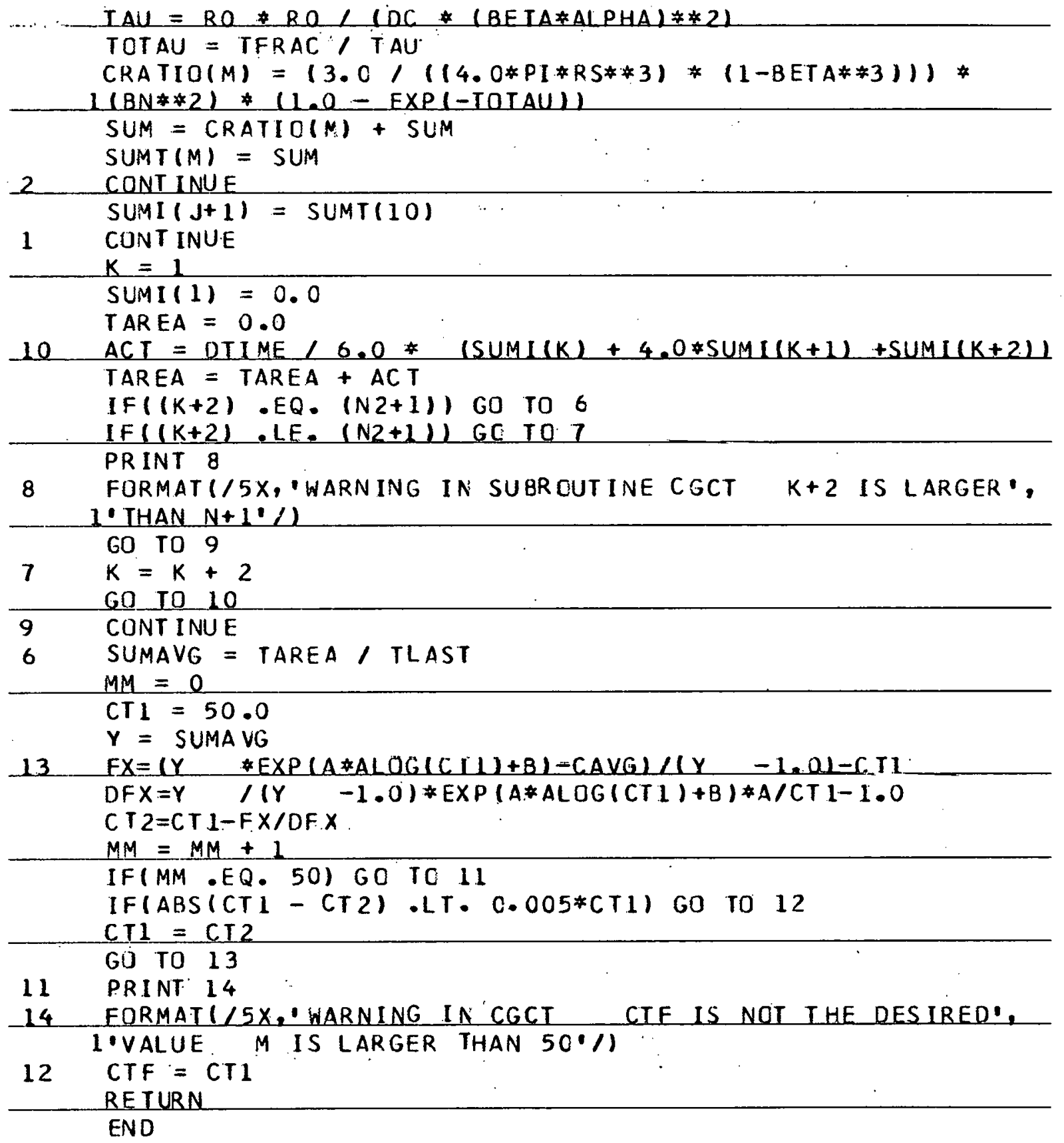


TABLE C.1 (Contd.)

SYSTEM INPUT PARAMETERS

TEMPERATURE $=873.00 \mathrm{~K} \quad 600.00 \mathrm{C}$

CARBON IN SODIUM $=0.5000 E .00$

IYPE OF SIEEL $=304$

INI TIAL CARBON CONC: 500.00

IN ITIAL CHROMIUM CONC. 18.00

RO -- PARIICLE RADIUS $0.5000 E-04$

RS - $1 / 2$ INTERPARTI ILE DISTANCE $0.7470 E-03$

CARBON CONCENTRATION, ACTIVITY GF CARBON,ANO SOLUBILITY OF

CARBON IN SODIUM

CNA $=0.500 E$ OO CSNA $=0.731 E$ O1 $\triangle C N A=0.684 E-01$

VALUES FOR THE CARBCN AND CHROMIUM CONCENTRATIONS AND THE

CARBON ACTIVITY IN AUSTENITE AT THE AUSTENITE/ AUSTENITE

+ CARBIDE PHASE BOUNCARY

$\begin{aligned} \text { CGSAT } & =12.50 \quad \text { CMSAT }=0.573 E-04 \quad \text { ACSAT }=0.118 E-03 \\ \text { CRBT } & =18.00 \quad \text { CRBTN }=0.191 \mathrm{E} 00\end{aligned}$

DC FOR 304 S.S. AT TEMP $=373.00$ IS $0.419 E-10$

CARBON AND CHROMIUM CONCENTRATICNS IN THE STEEL AT THE SODIUM-STEEL INTERFACE

CST $=6024.89$ CSG $=491.66 \quad C S N=0.2273 E-02$

CRSG $=5.793$ CRSN $=0.618 E-01$

INI TIAL CARBON AND CHROMIUM CONCENTRATIONS IN THE STEEL

CBT $=500.000 \mathrm{CBG}=112.299 \mathrm{CBM}=0.518 \mathrm{E}-03$
$\mathrm{CBTGCC}=0.402 \mathrm{E}-02 \mathrm{CRBG}=10.946 \mathrm{CRBM}=0.120 \mathrm{E} \mathrm{O1}$


TABLÉ C.1 (Contd.)

THIS IS THE CARBON IN AUSTENUIE VS ETA PROFILE

\begin{tabular}{clcccccc} 
I & \multicolumn{1}{c}{ EIA } & YMOLE & YD & YDD & CG & CRG \\
1 & 0.0 & $0.227 E-02$ & $-0.612 E-02$ & 0.0 & 491.67 & 5.79 \\
\hline 51 & $0.470 E-01$ & $0.199 E-02$ & $-0.606 E-02$ & $0.275 E-02$ & 429.65 & 6.26 \\
101 & $0.970 E-01$ & $0.169 E-02$ & $-0.583 E-C 2$ & $0.644 E-02$ & 365.19 & 6.83 \\
151 & $0.147 E$ & 00 & $0.141 E-02$ & $-0.541 E-02$ & $0.108 E-01$ & 304.25 & 7.47 \\
\hline 201 & $0.197 E$ & 00 & $0.115 E-02$ & $-0.474 E-02$ & $0.156 E-01$ & 249.18 & 8.16 \\
251 & $0.247 E$ & 00 & $0.935 E-03-0.386 E-02$ & $0.196 E-01$ & 202.50 & 8.89 \\
301 & $0.297 E$ & 00 & $0.767 E-03-0.283 E-02$ & $0.210 E-01$ & 166.27 & 9.58 \\
\hline 351 & $0.347 E$ & 00 & $0.651 E-03-0.182 E-02$ & $0.186 E-01$ & 141.21 & 10.15 \\
401 & $0.397 E$ & 00 & $0.582 E-03-0.102 E-02$ & $0.133 E-01$ & 126.09 & 10.54 \\
451 & $0.447 E$ & 00 & $0.545 E-03-0.494 E-03$ & $0.777 E-02$ & 118.16 & 10.77 \\
\hline 501 & $0.497 E$ & $0 C$ & $0.528 E-03-0.212 E-03$ & $0.383 E-02$ & 114.52 & 10.88 \\
551 & $0.547 E$ & 00 & $0.521 E-03-0.814 E-04$ & $0.164 E-02$ & 113.02 & 10.92 \\
601 & $0.557 E$ & 00 & $0.519 E-03-0.283 E-04$ & $0.626 E-03$ & 112.46 & 10.94
\end{tabular}

IIME IN SEC. $=0.31450 E 08$

TIME IN HRS. $=8736.00000$

TIME IN YEARS $=0.99726$

THIS IS THE CARBON IN AUSTENITE ANO TOTAL CARBON $\checkmark S X$ PROFILE AND THE MASS OF CARBON GAINED CR LCST PER SQUARE CENIIMETER CE IHE SIFEL

\begin{tabular}{|c|c|c|c|c|c|c|}
\hline$J$ & $X(C M)$ & $C G$ & $C T$ & ci2 & GRAMS & GDELX \\
\hline 1 & 0.0 & 491.7 & 6025.0 & $0.444 E-0.1$ & 0.0 & 0.0 \\
\hline 51 & $0.341 E-02$ & 429.7 & & & & \\
\hline 101 & $04 E-0$ & 365.2 & 48.3 & $53 F-01$ & -03 & 0.1095 \\
\hline 151 & $0.107 E-01$ & 304.3 & 31.5 & & & \\
\hline 201 & & & & & & \\
\hline 251 & $0.179 \mathrm{E}$ & 202.5 & & 22 & 0.40 & 04 \\
\hline 301 & & & & & & \\
\hline & & & & & & \\
\hline 401 & C. $288 \mathrm{E}-01$ & 126.1 & & $163 F-03$ & $0.441 F-03$ & $0.499 F-05$ \\
\hline 451 & $0.325 E-01$ & 118.2 & & $358 E-03$ & $0.443 E-03$ & $0.222 E-05$ \\
\hline 501 & & & & 235 & & 0.89 \\
\hline 551 & $0.397 \mathrm{E}-\mathrm{C}$ & & & $418 E-04$ & $0.444 E-03$ & $0.317 E-06$ \\
\hline 601 & $0.433 E-0$ & 11 & & $0.817 \mathrm{E}-0.5$ & $0.444 E-03$ & $0.906 E-07$ \\
\hline & C. $467 \mathrm{E}-01$ & 112 & 499 & $283 F-05$ & $0.444 E-03$ & $0.891 E-.08$ \\
\hline
\end{tabular}




\section{REFERENCES}

1. K. Natesan, T. F. Kassner, and Che-Yu Li, Effect of Sodium on Mechanical Properties and Friction-Wear Behavior of LMFBR Materials, Reactor Tech。15(4), 244-277 (1972-1973)。

2. V. Z. Jankus and R. Wo Weeks, LIFE-I, a FORTRAN-IV Computer Code for the Prediction of Fast-reactor Fuel-element Behavior, ANL-7736 (Nov 1970).

3. P. R. Huebotter, T. R. Bump, W. T. Sha, D. T。 Eggen, and P. J. Fulford, Design, Research, and Dovelopment Implicitions of Metal Swelling in Fast Reactors, ANL-7786 (Apr 1971).

4. P. R. Huebotter and T. R. Bump, "Implications of Metal Swelling in Fast Reactor Design," 1971 Int. Conf. on Radiation-induced Voids in Metals, Albany, N.Y. (June 9-11, 1971). (AEC Symp. Series 26, pp. 84-124.)

5. Interpretations of the ASME Boiler and Pressure Vessel Code, Case 1331-6 (1972).

6. Prodyot Roy, Gary P. Wozadlo, and Frank A. Comprelli, "Mas.s Transport and Corrosion of Stainless Steels in Flowing Sodium Systems at $1300^{\circ} \mathrm{F}, "$ in Proceedings of the International Conference on Sodium Technology and Large Fast Reactor Design: November 7-9, 1968, ANL-7520, Pt. I, pp. 131-142.

7. Summary Report, Sodium Mass Transfer. Program, Effects of Sodium Exposure on the Corrosion and Strength of Stainless Steels, General Electric Company, GEAP-10394 (Aug 1971).

8. S。A.Shie1s, C。Bagnall, and S. L。 Schrock, "Interstitial Mass Transfer in Sodium Systems," in Proc. Symp. on Chemical Aspects of Corrosion and Mass Transfer in Liquid Sodium. Sven A. Jansson, ed., AIME, New York, 1973, pp. 157-176.

9. Ralph H. Hiltz, Effect of High Temperature Sodium on Austenitic and Ferritic Steels. Mechanical Properties of Materials. Topical Report No. 6. Effect of Carburization on the Phases in Austenitic Stainless Steel, MSAR-66-119 (1966)。

10. L. H. Kirschler and R。C. Andrews, "Effect of High-temperature Sodium on the Mechanical Properties of Candidate Alloys for the LMFBR Program," in Proceedings of the International Conference on Sodium Technology and Large Fast Reactor Design: November 7-9, 1968, ANL-7520, Pt。 I, pp. 41-54.

11. Ro Stickler and A. Vinckier, Trans. ASM 54(1), 362-380 (Mar 1961).

12. H。F. Ebling and M. A. Scheil, "Time-Temperature-Sensitization (TTS) Diagrams for Types 347, 304L, and 316L Stainless Steels, "in Advances in the Technology of Stainless Steels and Related Alloys, ASTM-STP 369, pp. 275-284 (1965)。

13. B. Weiss and R. Stickler, Met。Trans。3(4), 851-866 (Apr 1972).

14. L. M。T. Hopkin and L。H。Taylor, J。Iron Steel Inst. 205(1), 17-27 (Jan 1967).

15. P. D. Goodell, T.M. Cullen, and J。W. Freeman, Trans. ASME, J。 Basic Eng. 517 (1967). 
16. P. G. Stone, High Temperature Properties of Steels, Proc。 Joint Conference organized by BISRA and ISI, 505 (1966)。

17. I. A. Rohrig, Symp. on The Effects of Residual Elements on Properties of Austenitic Stainless Steels, ASTM-STP 418, p. 78 (1967).

18. Jack K. Y. Hum and Nicholas J. Grant, Trans. ASM 45, 105-133 (1953)。

19. A. Thorley and C. Tyzack, "The Carburization of Stainless Steels in Sodium Containing Carbon Impurities and Its Effect on Mechanical Properties," BNES Intz. Conf on Corrosion, London, 1971, Paper 11, p. 143.

20. L. H. Kirschler, R. H. Hiltz, and S。 J. Rodgers, Effect of High Temperature Sodium on the Mechanical Properties of Candidate Alloys for the LMFBR Program, MSAR-70-76 (1970)。

21. C. N. Spalaris and E. L. Zebroski, Confo on Fast Reactor Fuel Element Technology, Am. Nuc.1. Soc. Trans.14, Supp1。1, 2-3 (1971)。

22. R。C. Andrews, R。H.Hiltz, L。 H。 Kirschler, S。J. Rodgers; and F. Tepper, Effect of High Temperature Sodium on Austenitic and Ferritic Steels. Topical Report No.4. Results of Mechanical Properties Tests of 316 SS Specimens in 1200 F Sodium Contominated with Carbon, MSAR-65-194 (1965).

23. F: N. Rhines, W。A。 Johnson, and W. A。 Anderson, Trans。 Met, Soc. AIME 147, 205-221 (1942)。

24. L. S. Darken, Trans。 Met.Soc。AIME 150, 157-171 (1942).

25. C. Wagner, Z. Elektrochem. 63, 772 (1959)。

26. J.H. Swisher and E. O. Fuchs, Trans. Met。Soc. AIME 245(8), 1789-1794 (1969).

27. Robert A。 Rapp, Corrosion 21(12), 382-401 (1965)。

28. D。E. Thomas, Trans, Met. Soc. AIME 191, 926-936 (1951)。

29. Car1 Wagner, Corros. Sci。8(12), 889-893 (1968).

30. IBM System/360 Scientific Subroutine Package, Version III, 337 (1970).

31. A. Thorley, B. Longson, and Jo Prescott, Effect of Exposure to Sodium on the Mechanical Properties and Structure of Some Ferritic, Austenitic, and High Nickel AZZoys, TRG-Report-1909 (1969).

32. W. J. Anderson and G. V. Sneesby, Carburization of Austenitic Stainless Steel in Liquid Sodium, NAA-SR-5282 (1960).

33. Gunji Nishio and Junichi Shimokawa, Process of Carburization in Austenite Stainless Steel, JAERI-Memo-4132 (1970).

34. G. 0. Haroldsen and.C. L. Livengood, The EBR-II Radioactive Sodium Chemistry Loop (RSCL), ANL/EBR-065 (Aug 1972).

35. $\mathrm{K}_{0}$ : Natesan and T. F. Kassner, Monitoring and Measurement of Carbon Activity in Sodium Systems, :Nucl.. Tech. 19, 46-57 (1973)。

36. EBR-II System Design Descriptions, Vol. II, Primary System, Chapter 3, E. Hutter, ed。(June 1971)。

37. R. H. Cambell, Construction and Engineering of PFR, Nucl. Eng. Int. 16(183), 636-640 (Aug 1971). 
38. G. Gajac, J. L。 Ratier, M。 Reboul, L. Reynes, and M。 A. Valantin, "Rapsodie's First Year of Operation," in Proceedings of the International Conference on Sodium. Technology and Large Fast Reactor Design: November 7-9, 1968, ANL-7520, Pt. II, pp 。52-64.

39. J.H. Westsik, Nuc1. Eng. Int. 16(181), 489-492 (June 1971).

40. Directory of Nuclear Reactors, Vol. IV, International Atomic Energy Agency, Vienna, p. 319 (1962).

41. B. Wolfe, A。 S。 Gibson, P.M. Murphy, and D。R. Sawle, The Influence of Component Development, Prototypes, and Constmuction Experience Towards a 1000 MWe LMFBR, Nuc1. News 16(1), 35 (19.73).

42. W. E. Ruther, T. D. Claar, S. Greenberg, and R. V. Strain, MaterialsCoolant Interactions in EBR-II; ANL-7670 (Mar 1970).

43. I. R. Kramer, Trans. Met. Soc. AIME 227(4), 1003-1010 (Aug 1963).

44. I. R. Kramer, Trans: Met. Soc. AIME 230(5), 991-1000 (Aug 1964).

45. R. P. Agarwala, M. C. Naik, M。 S. Anand, and A. R. Paul, J. Nucl. Mater. 36, 41-47 (1970).

46. C. Bagnal1, Westinghouse Advanced Reactor Division, Madison, Pa., private communication (1972).

47. K。 Natesan and T。F。Kassner, Thermodynomics of Carbon. in Nickel, Iron-Nickel and Iron-Chromium-Nickel AlZoys, to be published in Met. Trans :

48. H. Tuma, P. Grobner, and K. Lob1, Arch. Eisenhuttenwesen 4, 727 (1969).

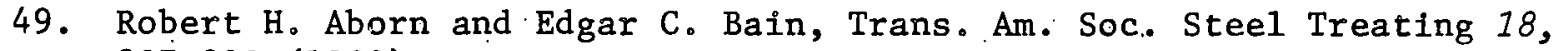
837-893 (1930).

50. V. N. Krivobok and M. A. Grossmann, Trans. Am. Soc. Steel Treating 18, 808-836 (1930)。

51. 0.V. Greene, Discussion, Trans: Am. Soc。Steel Treating 18, 877-879 (1930).

52. S. J. Rosenberg and C. R. Irish, J. Res. Nat. Bur. Stand.48, 40 (1952)。

53. K. Natesan and T。 F. Kassner, "Thermodynamics of Carbon Transfer in Sodium-Steel Systems," in Proc. Symp on Chemical Aspects of Corrosion. and Mass Transfer in Liquid Sodium, Sven A. Jänsson, ed., AIME, New York, 1973, pp. 157-176.

54. Frank V. Nolfi, Jr., Paul G. Shewmon, and James S。Foster, Trans: Met。 Soc. AIME 245(7), 1427-1433 (July 1969).

55. J. G. Gratton, Solubility of Carbon in Sodium at Elevated Temperatures, KAPL-1807 (1957).

56. C. Luner, A. Cosgarea, and H. M. Feder, Solubility of Carbon in Sodium, Symposium on Alkali Metal Coolants, Vienna (Dec 1966).

57. B. Longson and A.W. Thorley, J。Appl。Chem。20, 372 (1970)。

58. D. C. Gehri, The Behavior of Carbon in Liquid Sodium, AI-AEC-12826 (1970). 
59. F. J. Salzano and L. Newman, Nucl。Tech。13(3), 289-296 (Mar 1972)。

60. C. C. Miles, Anal. Chem. 41, 1041 (1969).

61. Reactor Development Program Progress Report: November 1972, ANLRDP-11, p. 1.7. (Jan 2, 1973). 